\author{
UNIVERSIDADE DE BRASÍLIA \\ INSTITUTO DE CIÊNCIA POLÍTICA \\ PROGRAMA DE PÓS-GRADUAÇÃO EM CIÊNCIA POLÍTICA
}

\title{
Concentração da riqueza e democracia: os efeitos políticos da desigualdade material
}

Dissertação a ser apresentada no mestrado acadêmico em Ciência Política do Instituto de Ciência Política da Universidade de Brasília, como requisito para a obtenção do título de Mestre em Ciência Política.

Aluna: Nayara F. Macedo de Medeiros

Orientador: Luis Felipe Miguel

BRASÍLIA 


\section{Concentração da riqueza e democracia: os efeitos políticos da desigualdade material}

Dissertação a ser apresentada no mestrado acadêmico em Ciência Política do Instituto de Ciência Política da Universidade de Brasília, como requisito para a obtenção do título de Mestre em Ciência Política.

BANCA EXAMINADORA:

Prof. Dr. Luis Felipe Miguel (orientador), Universidade de Brasília.

Profa. Dra. Flávia Biroli, Universidade de Brasília.

Prof. Dr. Francisco Mata Machado Tavares, Universidade Federal de Goiás.

Suplente - Prof. Dr. Paulo Nascimento, Universidade de Brasília. 


\section{AGRADECIMENTOS}

Primeiramente, agradeço a Deus e à minha família, por ter desde cedo incentivado meus estudos, providenciando as condições econômicas e emocionais para isso. Tenho a plena consciência de que se não fosse o suporte financeiro por parte dos meus pais e da minha tia Vanessa durante a graduação e o mestrado não poderia ter me dedicado com tanto esmero. Também a própria trajetória de esforço pessoal deles e a priorização dos meus estudos desde a infância foram relevantes para minha formação acadêmica.

Aos colegas Márcio Mello e Noëlle Silva, assim como ao Daniel, pela ajuda indispensável na busca de alguns dados. Ao grupo de pesquisa Demodê, pela oportunidade de inúmeros debates acerca da temática, os quais foram essenciais ao amadurecimento desse processo de pesquisa. Destaco aqui o papel da professora Danusa Marques e do professor Carlos Machado na orientação das atividades do grupo. Não pode ser esquecida também uma menção a todos/as funcionários/as e professores/as do IPOL pela qualidade do trabalho realizado, pois dele depende o bom funcionamento de todas as atividades do mestrado.

Ao Conselho Nacional de Desenvolvimento Científico e Tecnológico (CNPq), por ter propiciado o auxílio financeiro que permitiu a dedicação exclusiva ao mestrado durante o primeiro ano. Tal exclusividade foi indispensável para o desenvolvimento das atividades feitas durante o mestrado, principalmente no que tange à conclusão das disciplinas e ao trabalho feito na dissertação.

De forma semelhante, cabe um agradecimento aos gestores e colegas da Diretoria de Direitos Intelectuais (DDI), do Ministério da Cultura, pela paciência e compreensão com as mudanças de horários devido à necessidade de estar presente eventualmente na UnB.

É evidente que não poderia deixar de agradecer ao professor Luis Felipe Miguel, pelas críticas sempre pertinentes e pela orientação exemplar, assim como aos membros da banca por aceitarem o convite feito.

Por fim, agradeço ao Luís Paulo por ter suportado todos os meus momentos de euforia e porque eu sei que ele vai me ajudar nessa revisão final. 


\section{ÍNDICE}

I. INTRODUÇÃO

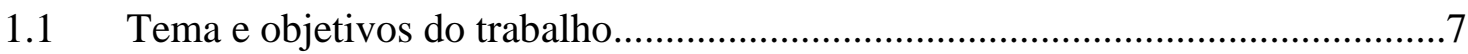

1.2 Observações de cunho metodológico................................................................. 10

II. DEMOCRACIA E DESIGUALDADE: ABORDAGENS TEÓRICAS...........13

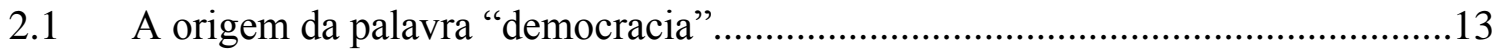

2.2 O paradigma liberal e o pluralismo: da democracia concorrencial à poliarquia....17

2.3 A Democracia Deliberativa: igualdade e esfera pública........................................30

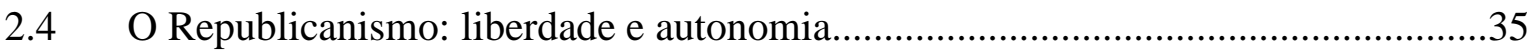

2.5 A Democracia Participativa: socialização e independência econômica....................41

2.6 Multiculturalismo e teorias da diferença: a questão dos grupos minoritários..........47

2.7 Marxismo: a interação entre Estado e Sociedade.......................................................53

2.8 O debate sobre modernização: mecanismos entre distribuição de renda/riqueza e

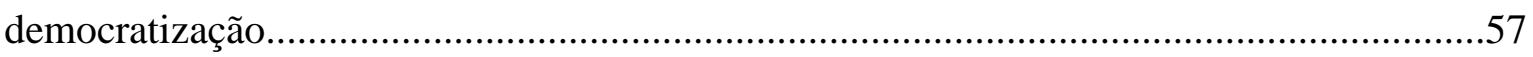

2.9 Esboço de quadro teórico: um esforço de sistematização da relação entre renda e democracia.

III. MECANISMOS ENTRE DISTRIBUIÇÃO E DEMOCRACIA......................76

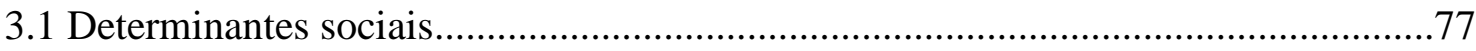

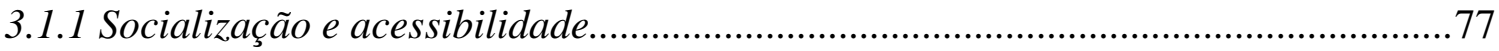

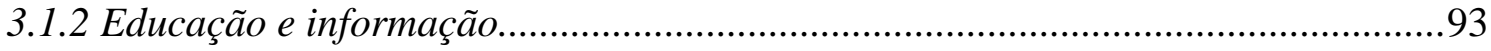

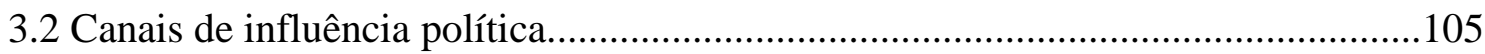

3.2.1 Financiamento de campanhas e ocupação de cargos eletivos.................................107

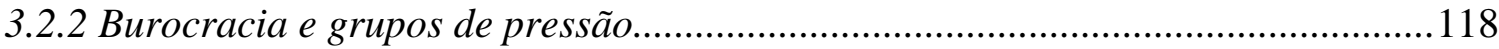

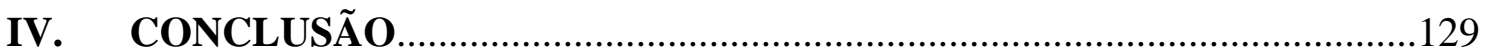

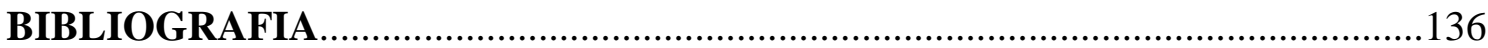




\section{FIGURAS, QUADROS, GRÁFICOS E TABELAS:}

Figura 1 - Resumo esquemático da proposta de dissertação........................................9

Figura 2 - Sistematização da relação entre os conceitos.............................................75

Figura 3 - Relação entre condicionantes e acesso ao sistema político.........................130

Quadro 1 - Mecanismo causal descrito por Lipset (1959).........................................59

Quadro 2 - Mecanismo da socialização/acessibilidade.............................................92

Quadro 3 - Mecanismo da informação/educação........................................................105

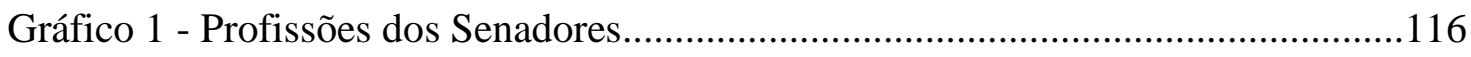

Gráfico 2 - Nível de instrução dos Senadores.......................................................117

Tabela 1 - Correntes do pensamento político..........................................................74

Tabela 2 - Associativismo e mobilização sociopolítica no Brasil (2006)......................80

Tabela 3 - Participação no Orçamento Participativo (Porto Alegre)..............................84

Tabela 4 - Socialização em cidades selecionadas, 2006-2008......................................85

Tabela 5 - Conhecimento das regras e critérios do OP e falar no OP, Porto Alegre.......89

Tabela 6 - Proporção de pessoas de 18 a 24 anos de idade, com menos de 11 anos de

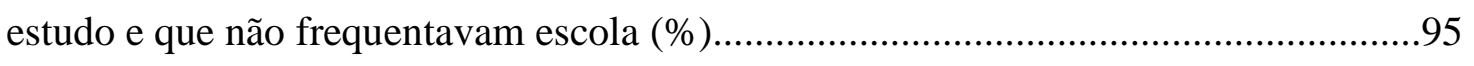

Tabela 7 - Média de anos de estudo das pessoas de 18 a 24 anos de idade por quintos de rendimento mensal familiar per capita nacional.....................................................96

Tabela 8 - Conhecimento das regras e critérios por tempo de OP e nível de ensino......97

Tabela 9 - Costuma falar nas reuniões do OP, tempo de OP e níveis de ensino............97

Tabela 10 - Mobilização política e escolaridade, médias do Brasil (2006)....................98

Tabela 11 - Fonte de informação mais importante na decisão do voto (2010)...............100

Tabela 12 - Financiamento de campanhas e contratos públicos (2012).....................109

Tabela 13 - Desembolsos pós-embarque por empresa exportadora (2010-2013).......112 


\title{
Concentração da riqueza e democracia: os efeitos políticos da desigualdade material
}

\author{
"L'océan défend l'eau, l'ouragan défend l'air; le roi défend la royauté, la \\ démocratie défend le peuple..." (Victor Hugo)
}

Resumo: A relação entre igualdade econômica e democracia tem sido abordada desde as primeiras discussões sobre formas de governo. No entanto, por mais que grande parte das correntes de pensamento político aborde a questão, poucas delas especificam o que estaria no "meio" dessa relação. O presente trabalho apresenta uma sistematização teórica acerca da questão, mostrando quais são os mecanismos pelos quais a distribuição de renda e riqueza impacta o regime democrático. Isso é feito por meio de uma revisão crítica da literatura, principalmente no que concerne à teoria democrática. Dessa maneira, analisa-se a vertente liberal-pluralista, a democracia deliberativa, a democracia participativa, o republicanismo, o multiculturalismo, o marxismo e as teorias da modernização de modo a discutir como essas correntes abordam o papel da igualdade econômica na democracia e o valor da participação popular. Nota-se que o papel atribuído à igualdade econômica varia de acordo com a importância atribuída à participação. Supõe-se que uma distribuição igualitária de renda e riqueza colabora para uma democracia efetiva, pois estaria relacionada à maior igualdade no acesso dos cidadãos e cidadãs ao poder político. Assim, renda e riqueza incidem sobre fatores como educação, acesso à informação, socialização, os quais possibilitam que indivíduos adquiram habilidades e interesses relacionados à política. Sobretudo, essas habilidades e interesses se constituem em produtos sociais influenciados pelo status socioeconômico. De forma semelhante, canais importantes de acesso ao processo político - como os grupos de pressão e o contato com a burocracia dependem, em larga medida, desses fatores e da posição que os indivíduos ocupam na sociedade. O contexto brasileiro é analisado por meio de dados secundários para trazer uma luz sobre essas questões.

Palavras-chave: democracia, desigualdade, teoria política.

Abstract: The relationship between economic equality and democracy has been approached since the first discussions about political regimes. Although many streams of political thought analyze this topic, few of them specify what mediates this relationship. 
This work presents a theoretical systematization about the subject, enlightening the mechanisms through which distribution of income and wealth affects the democratic regime. This is done through a critical review of the literature on political theory, approaching mainly democratic theories. Therefore, it analyses Liberal-pluralism, Deliberative Democracy, Participative Democracy, Republicanism, Multiculturalism, Marxism and the theories of modernization in order to discuss how political thought approaches the role of economic equality on democracy and the value of popular participation. It is noted that the role played by economic equality varies according to the relevance given to political participation. It is supposed that an equal distribution of income and wealth contributes to a substantive democracy since it is related to more equity in terms of citizen access to political power. Thus, income and wealth affect factors such as education, access to information, socialization, all of which promote individuals' abilities and interests related to politics. Moreover, these abilities and interests are social constructs affected by socioeconomic status. Similarly, important contact channels for taking part in the political process, such as lobby groups and bureaucracy, depends in a large extent upon these factors and the position that an individual occupies in society. The Brazilian context is analyzed through secondary data in order to shed light to these matters.

Keywords: democracy, inequality, political theory. 


\section{I \\ INTRODUÇÃO}

\subsection{Tema e objetivos do trabalho}

O imaginário popular acerca do termo "democracia" aponta para a predominância da palavra "povo". De fato, o sentido original da palavra corresponde aos termos "demos" e "kratos", que em conjunto denotam "governo do povo". No entanto, tal expressão suscita questões em torno das palavras "governo" e "povo", como quem faz parte do "povo" e o que significa governar (Held, 2007 [2006]).

Assim, a palavra "democracia" adquire diversos significados que se distinguem substancialmente entre si, de acordo com as definições que são atribuídas a povo e a governo, principalmente no que tange à participação popular. Um dos significados mais utilizados corresponde à democracia representativa, que abrange a maior parte dos regimes ocidentais.

Nesse sentido, é notável que grande parte dos regimes atualmente converge para a defesa de certas condições institucionais, como eleições livres e periódicas, liberdade de imprensa e associação, pluripartidarismo, seja devido à viabilidade dessas condições face à difícil operacionalização da participação popular direta ou à adesão aos valores liberais. No entanto, cabe questionar se a mera presença de tais condições seria suficiente para o efetivo funcionamento do regime democrático. A partir do momento em que o foco é deslocado para o funcionamento e para a qualidade em vez da presença ou ausência de regras formais, outros aspectos além do aparato institucional se tornam relevantes.

Um dos principais é o econômico, pois é plausível supor que fatores econômicos tenham grande impacto nas formas pelas as quais as instituições e as normas funcionam e na maneira pela qual os indivíduos ganham acesso e reagem a essas normas e instituições. O exercício de atividades políticas implica em certos custos materiais: mesmo o ato de votar requer, no mínimo, que o indivíduo arque com o transporte até o local do voto.

Sobretudo, elementos socioeconômicos, como renda e controle sobre riquezas, incidem sobre o acesso a determinados espaços, os quais são necessários na aquisição de habilidades e capacidades comumente associadas à participação política. Locais como 
escolas e igrejas, por mais que não sejam espaços diretamente políticos, possuem impacto em como os cidadãos desenvolvem capacidade e interesse relacionados à atividade política.

Ademais, nesses locais, indivíduos entram em contato com diversos tipos de informação e instrução, os quais também podem moldar diferentes ações políticas. É razoável supor, portanto, que uma diferença substancial no campo econômico é reproduzida no político, pois a obtenção de recursos materiais implica no acesso a instrumentos intermediários que incidem sobre as oportunidades de contato com o sistema político. Dessa forma, a interação entre a esfera política e a econômica não pode ser negligenciada no estudo da democracia.

Esse trabalho possui dois objetivos principais: o primeiro é discutir a interação entre igualdade econômica e igualdade política na teoria democrática de modo a delinear como a literatura aborda os efeitos da concentração de recursos econômicos na democracia; já o segundo corresponde à análise do contexto brasileiro no que tange à desigualdade econômica e seus possíveis impactos no regime democrático. Os dois objetivos estão relacionados, visto que "distribuição de renda e riqueza" atua como uma aproximação de igualdade econômica, enquanto "democracia" foi escolhida para representar a igualdade política.

Tal escolha baseia-se no argumento de que distribuição de renda e riqueza é uma dimensão importante da igualdade econômica, embora não seja a única, enquanto democracia relaciona-se com igualdade política devido ao sentido original estar associado à distribuição igualitária de poder político. Nesse sentido, renda refere-se aos rendimentos recebidos pelos indivíduos, como os salários e rendas auferidas de outras atividades, enquanto riqueza corresponde ao controle sobre capital econômico.

Já a democracia é entendida como "distribuição igualitária do poder político". Essa definição é construída com base em uma revisão das principais correntes de pensamento político relacionadas à teoria democrática, desde a origem do termo até as suas concepções mais recentes.

Dessa forma, o presente trabalho pretende propor reflexões acerca da relação entre distribuição de renda/riqueza e democracia de forma a analisar de que forma a distribuição de renda/riqueza afeta a qualidade do regime democrático, definida por uma maior distribuição de poder. Como o poder se trata de um conceito de difícil operacionalização, 
essa distribuição é analisada por meio da avaliação das oportunidades de acesso à política das quais dispõem os indivíduos que compõem a sociedade, segundo suas posições socioeconômicas. Assim, questiona-se como renda e riqueza afetam as oportunidades de participação política.

A intenção principal é, portanto, a sistematização dos mecanismos pelos quais a distribuição de renda e riqueza geram impactos na democracia - conforme ilustrado na Figura 1.

Figura 1 - Resumo esquemático da proposta de dissertação

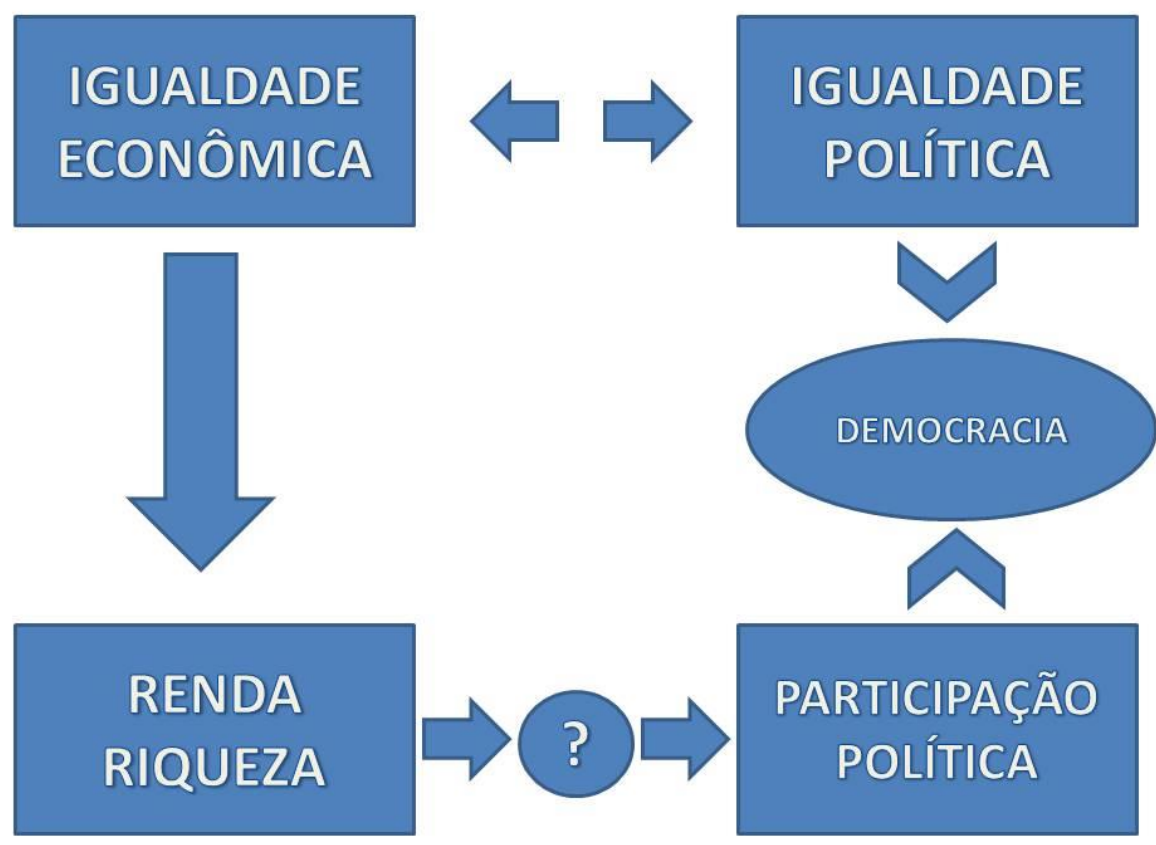

Para os fins desse trabalho, presume-se que renda e riqueza estariam associadas a elementos que condicionam a participação política, o que, por sua vez, constitui-se em um atributo essencial da democracia. O objetivo aqui não é analisar as dinâmicas das desigualdades econômicas ou as suas causas, mas seus efeitos no regime democrático. Inspirando-se na linguagem da sociologia de Bourdieu (2011), a política é considerada um campo restrito. $\mathrm{O}$ que se pretende analisar é justamente como renda e riqueza afetam o acesso dos "profanos" a esse campo.

Em “Capitalism development and democracy”, Rueschemeyer, Stephens e Stephens (1992: 29) afirmam que as forças causais por trás da relação entre desenvolvimento e democracia estariam em uma "caixa preta". O mesmo ocorre com a relação entre 
distribuição de renda e democracia: existem trabalhos que buscam demonstrar que há correlação entre as duas variáveis, mas poucos realmente desvendam o que estaria na "caixa preta". Começar a abrir essa caixa é a principal finalidade dessa dissertação.

Pretende-se, assim, propor respostas à pergunta "Como distribuição de renda e riqueza pode afetar a democracia?", construindo um esboço de enquadramento teórico que considere os "caminhos" pelos quais renda e riqueza condicionam a participação política. Isso será feito por meio de um diálogo com a literatura acerca do tema. A intenção é analisar e discutir como essa literatura aborda essa temática e quais os efeitos dessas abordagens no desenvolvimento de posteriores trabalhos empíricos. A revisão bibliográfica constitui-se em uma análise da forma com a qual os autores enxergam o problema em questão.

Nesse sentido, busca-se refletir acerca de como a teoria democrática tem discutido essa questão e comparar com dados extraídos de pesquisas empíricas nos diversos tópicos que tal temática abrange. Os dados referem-se ao contexto brasileiro, mostrando os potenciais e os limites de uma agenda de pesquisa nessa área e a aplicação de teorias "vindas de fora" a um contexto distinto. Assim, espera-se formular novas hipóteses sobre a relação entre renda, riqueza e democracia, contribuindo para que futuros testes sejam realizados em cada subtemática.

O trabalho está dividido em três capítulos, além da introdução. O segundo capítulo mostra uma revisão bibliográfica acerca dos conceitos de democracia e as consequências da escolha desses conceitos na análise da relação entre distribuição de renda/riqueza e regime democrático. Com base nessa revisão, é feito um esboço de sistematização teórica.

O terceiro capítulo analisa de forma mais aprofundada as condições pertencentes ao esboço, apresentando alguns dados extraídos da realidade do Brasil de forma a analisar quais são os limites das teorias discutidas em relação ao contexto brasileiro. Por fim, a conclusão pretende apresentar reflexões extraídas do trabalho feito e indicações de próximos passos da investigação empírica da temática. Antes de prosseguir com os capítulos, porém, é necessário fazer alguns esclarecimentos de teor metodológico.

\subsection{Observações de cunho metodológico}

O foco central desse trabalho é a construção teórica dos mecanismos que ligam distribuição de renda/riqueza à democracia, os quais poderiam ser testados empiricamente 
em pesquisas posteriores. Essa construção será feita com base em uma revisão crítica da literatura acerca da democracia e do debate sobre modernização e em uma análise exploratória de dados.

As várias correntes do pensamento político - liberal-pluralismo, deliberacionismo, participacionismo, republicanismo, multiculturalismo e marxismo - ligadas à teoria democrática são utilizadas devido à importância da escolha do conceito de democracia na forma com a qual é vista a relação entre igualdade econômica e política. Democracia é um termo que possui significados diversos e a opção pela utilização de um ou outro conceito condiciona como a distribuição de renda/riqueza é vista em relação aos seus impactos no regime democrático.

Assim, a revisão bibliográfica feita com base nas vertentes da teoria democrática intende explorar os diversos significados que a palavra "democracia" assumiu, assim como as implicâncias da escolha de determinados conceitos na avaliação da relação entre igualdade política e econômica. Essa parte da dissertação visa, portanto, a analisar como as correntes definem democracia e como elas enxergam a relação entre a esfera política e a econômica, abordando os impactos da desigualdade socioeconômica no regime democrático. Ademais, essa revisão é necessária para a própria construção do conceito de democracia a ser utilizado nesse trabalho.

Já o debate sobre teorias da modernização é utilizado devido ao tratamento que ele confere diretamente aos mecanismos que ligariam a questão da renda e do controle de recursos econômicos com a democratização. Grande parte das teorias que permeiam essa discussão está centrada no papel das classes sociais no processo de democratização. Dessa forma, as teorias relacionadas ao debate sobre modernização são utilizadas para auxiliar mais diretamente a construção acerca dos possíveis "caminhos" que ligariam distribuição de renda/riqueza à democracia.

Em suporte à discussão teórica, é feita uma análise exploratória de dados extraídos do Brasil em relação aos mecanismos delineados na revisão bibliográfica de forma a coletar evidências acerca do funcionamento de tais mecanismos em relação ao raciocínio exposto pelas teorias abordadas. Identificar mecanismos, nesse sentido, significa explicar em detalhe as "engrenagens e rodas" do processo causal (Hedström \& Ylikoski, 2010). Entretanto, não há pretensões de fortes inferências causais, uma vez que a realização de testes empíricos foge ao escopo desse trabalho. 
Destarte, esse trabalho constitui-se em um esforço de sistematização de um quadro teórico sobre a relação entre distribuição de renda/riqueza e a democracia por meio da identificação de "caminhos" que ligariam renda e riqueza à democracia.

Como uma análise de um fenômeno macro e que abrange conceitos não consensuais, a pesquisa apresenta uma série de limites de cunho metodológico. Primeiramente, há de se destacar que, embora se tenha um parâmetro acerca dos indicadores econômicos, a questão se torna mais complexa em relação ao tema da democracia. Embora existam índices que mensurem a qualidade da democracia, optou-se pela construção de um modelo e pela busca de evidências empíricas que o suportasse. Assim, a discussão teórica auxiliaria na formulação de um conceito de democracia, porém sem oferecer plena precisão.

Sobretudo, há muitos elementos na dimensão política que são difíceis de mensurar: a participação política fora das instituições, por exemplo, não é de fácil apreensão, devido principalmente à obstrução do acesso a dados que indiquem informações sobre esse tipo de comportamento específico. Não se sabe se há registros dessa espécie. Por fim, devido à ausência de testes empíricos mais rigorosos, o escopo de generalização e nível de significação do modelo podem ser questionados. Por basear-se em um contexto específico - o do Brasil - seria necessária a realização de mais estudos para apoiar a generalização dos resultados. O trabalho está, porém, permeado por diversas sugestões em torno de uma agenda de pesquisa específica nessa temática e em suas ramificações. 


\section{II \\ DEMOCRACIA E DESIGUALDADE: ABORDAGENS TEÓRICAS}

\subsection{A origem da palavra "democracia"}

Por mais que a palavra "democracia" seja largamente utilizada como um ideal normativo, sua realização se distingue em muitos aspectos de seu modelo original, o grego. O modelo grego tinha como fatores elementares a assembleia popular, o sorteio como forma de preenchimento de cargos públicos, a rotatividade nas posições de governo, entre outros elementos que não estão presentes nos regimes democráticos contemporâneos (Miguel, 2005).

Uma das diferenças primordiais entre o sentido original da palavra na Grécia e as formas contemporâneas que o termo assumiu é o papel da participação popular e, consequentemente, da representação. Ao passo que democracia e representação são frequentemente associadas na visão atual, os dois conceitos eram vistos como opostos na Grécia Antiga. As eleições - entendidas, aqui, como uma instituição representativa - eram vistas como um método oligárquico, ou seja, contrapunham-se ao conceito de democracia (Manin, 1997).

Para entender a discrepância entre o sentido original e as formas contemporâneas de democracia, é necessário ter em mente dois pontos essenciais nesse debate: a classificação das formas de governo, tal como exposta no pensamento grego e o papel atribuído à igualdade no conceito original de democracia.

Na clássica classificação aristotélica, são consideradas seis formas de governo, das quais três equivalem a regimes considerados positivos e os outros três à degeneração dos regimes positivos. As seis formas de Aristóteles recebem o nome de monarquia, aristocracia, governo constitucional ${ }^{1}$, tirania, oligarquia e democracia (Tilly, 2006).

\footnotetext{
${ }^{1}$ Cabe aqui um esclarecimento terminológico: o termo "politia" é utilizado para designar a democracia (como "governo de muitos") como forma positiva na classificação de Aristóteles. Entretanto, o termo é utilizado também de forma genérica para designar "constituição" (ver Bobbio, 2000). Portanto, optou-se, nesse trecho, pela utilização do termo "governo constitucional”, como em Tilly (2006).
} 
Os critérios utilizados nessa classificação são dois: o número associado a quem governa (um, poucos ou muitos) e se o governante age em prol do interesse público ou de seu interesse privado. Assim, Tilly (2006: 8) afirma que, segundo o princípio aristotélico, a monarquia adequada baseava-se no governo do melhor homem, a aristocracia no governo dos homens melhores e ricos, e o governo constitucional estava relacionado aos homens livres.

Vale ressaltar que, no pensamento aristotélico, "muitos" e "poucos" acabam correspondendo às posições socioeconômicas dos pobres e dos ricos, pois os ricos são geralmente poucos em número assim como os pobres são numerosos. Nesse sentido, a democracia - na visão aristotélica - era o governo dos pobres em discriminação ao interesse coletivo do Estado e aos interesses dos ricos. Esse tipo de situação estaria sujeito ao atiçamento das massas pelos demagogos com a finalidade de atacar os ricos e deter o poder em interesse próprio (Tilly, 2006).

É importante lembrar, porém, que o conceito de "cidadão" na Grécia Antiga era muito restrito, uma vez que mulheres, estrangeiros e escravos estavam excluídos dessa denominação e, portanto, fora da participação política. Dessa forma, o "muitos" refere-se a um número muito menor em termos comparativos ao contingente populacional de hoje (além de outras diferenças relacionadas à extensão territorial e crescimento populacional). Cabe destacar que até mesmo no pensamento aristotélico, as mulheres e os escravos eram vistos como naturalmente inferiores (ver Bobbio, 2000; Tilly, 2006).

A forma positiva mais viável, segundo Aristóteles, seria uma combinação da oligarquia com a democracia, que se justificava pela presunção de que essa combinação geraria a mediação do conflito entre os pobres e ricos (os que não possuem e os proprietários). Essa combinação se efetivaria por meio da conciliação de procedimentos que seriam incompatíveis, da adoção de um "meio termo" entre as disposições extremas dos dois regimes e da seleção do melhor dos dois sistemas legislativos (Bobbio, 2000).

A adoção de um "meio termo", por exemplo, poderia consistir em "diminuir o limite mínimo de renda imposto pelo regime dos ricos, elevando o admitido no regime dos pobres" (Bobbio, 2000:61). Assim, um fator relevante a ser destacado aqui é a importância da posição econômica no pensamento de Aristóteles. Tendo em vista que uma das características das formas de governo classificadas é justamente o fato de ser um governo 
de ricos ou de pobres, conclui-se que a renda é um aspecto predominante. Ademais, a existência de uma larga classe média é associada à estabilidade.

Mais que um mero critério na definição das formas de governos, a renda está relacionada, aqui, ao próprio cerne do conceito de democracia, uma vez que ela é definida como "um governo de muitos" ou "governo dos pobres". O próprio conceito de "povo" identifica-se com a parcela da população mais desprovida em termos de recursos econômicos, uma vez que governo do povo passa a corresponder a governo dos pobres. $\mathrm{O}$ aspecto interessante nessa constatação é analisar o quanto o papel da renda foi mitigado ou enfatizado nas definições posteriores - análise que será feita nas subseções em sequência.

Assim, nota-se que a forma pela qual a democracia era vista na Antiguidade Clássica se difere bastante da usual utilização do termo na contemporaneidade: primeiramente, democracia estava relacionada com um governo de muitos, ou das massas, ou do povo, em que as decisões públicas estão vinculadas a um largo número de indivíduos $^{2}$, e, em segundo lugar, democracia era vista como uma forma negativa, diferentemente da conotação positiva que adquiriu em décadas mais recentes.

Uma diferença ainda mais discrepante é, porém, o papel da igualdade política. No contexto grego, democracia implicava em uma comunidade política na qual existe certo nível de igualdade política (Held, 2007 [2006]) ${ }^{3}$.

A igualdade, nesse sentido, não se referia a uma igualdade de resultados ou de oportunidades, mas de chances em termos de probabilidade. Dessa forma, a igualdade não se manifestava na distribuição efetiva do poder, mas nas chances iguais de exercê-lo expressas na utilização de métodos como sorteio e na rotatividade dos cargos públicos (ver Manin, 1997). Quando o ocupante do cargo é escolhido por sorteio, todas as pessoas possuem a mesma probabilidade de efetivamente ser escolhidas.

\footnotetext{
${ }^{2}$ Vale destacar que a relação entre indivíduo e Estado na Antiguidade Clássica também era vista de maneira distinta da contemporaneidade. Mas considerações aprofundadas a esse respeito fogem do escopo desse trabalho.

${ }^{3}$ A diferença comumente destacada reside na manifestação do exercício do poder: o que gerou a distinção entre democracia direta e indireta foi o fato de que em Antenas o governo era centrado no exercício direto do poder, em contraste com o modelo democrático baseado no método eleitoral (ver Heywood, 2004). Geralmente, quando essa diferenciação é levantada, traz-se o papel da assembleia popular na Grécia. Entretanto, Manin (1997) mostra que esse não era o único órgão no qual residia o poder, tampouco ele detinha uma concentração larga do poder. Havia métodos como o sorteio para o preenchimento de alguns cargos (em algumas situações, o método eleitoral era utilizado) e a rotatividade, a qual fazia com que as pessoas se intercalassem na posição de governantes e governados.
} 
De forma semelhante, os maiores defensores da democracia representativa argumentam que o exercício direto do poder pelo povo não é possível em comunidades de largos territórios, visto que na Grécia Antiga esse modelo se sustentava devido ao baixo número de cidadãos (pela restrição desse conceito) e ao tamanho reduzido das comunidades políticas (Heywood, 2004).

Todavia, Manin (1997) argumenta que a viabilidade (ou falta de) não foi a principal razão pela qual o método eleitoral foi escolhido, sendo fruto de uma escolha em que a legitimidade preponderou sobre o princípio de igualdade. Nesse sentido, o mais importante deixava de ser a distribuição igualitária dos cargos e passava a ser o consentimento das pessoas que estavam sendo governadas. Por mais que esse "novo" princípio negligenciasse em certa medida a questão distributiva, ele ainda se mostrava mais igualitário do que um princípio utilizado em período precedente, isso é, a hereditariedade (Manin, 1997).

Dessa discussão preliminar, pode-se inferir que igualdade, de certa forma, está relacionada a uma questão de acesso ao sistema político. Na Grécia Antiga, esse acesso ocorria por meio de sorteio e de rotatividade nos preenchimentos dos cargos, em que os cidadãos possuíam chances relativamente semelhantes de acesso ao sistema político através da ocupação de um cargo público. O significado que permeará o conceito de igualdade política nesse trabalho será, portanto, o acesso, entendido como sua relação com a permeabilidade do sistema político aos cidadãos comuns.

Uma vez entendida como acesso, a igualdade política levanta a questão dos obstáculos. Quais seriam os obstáculos para o acesso ao sistema político? Held (2007 [2006]: 21) apresenta como outra questão que permeia a democracia: "é necessário certo nível de riqueza social para a manutenção da democracia?”.

Essa questão abrange, aqui, duas dimensões em relação à permanência do regime democrático: a primeira relaciona-se à indagação sobre a necessidade de certo patamar mínimo de riqueza, enquanto a segunda refere-se, de forma mais específica, ao questionamento sobre se há necessidade de diminuir o hiato entre as riquezas e rendas dos indivíduos para que vigore a democracia.

Embora as duas questões sejam distintas, elas estão interligadas, pois ambas rementem aos obstáculos que os indivíduos enfrentam em relação às oportunidades de participação política. A intenção desse trabalho é redefinir democracia com base no acesso 
ao sistema político. Logo, os obstáculos precisam ser considerados, principalmente na discrepância com a qual eles afetam indivíduos de diferentes posições sociais.

Resta indagar qual o papel da renda nesses obstáculos e, portanto, no acesso ao sistema político. Antes de analisar essa questão de forma mais aprofundada, torna-se necessário fundamentá-la no campo teórico. Os tópicos seguintes expõem a relação entre democracia e desigualdade nas diversas vertentes da teoria democrática com a finalidade de ressaltar as diferenças nos conceitos utilizados e nas consequências dessas diferenças na análise do papel da desigualdade social no regime democrático ${ }^{4}$.

\subsection{O paradigma liberal e o pluralismo: da democracia concorrencial à poliarquia}

A palavra "democracia" possui diversos significados que variam de acordo com a perspectiva teórica, o período e a sociedade em que estamos inseridos. Muito do seu sentido original, inerentemente ligado à igualdade política, perdeu-se ou ao menos deu espaço a outras prioridades que foram surgindo, como a necessidade de legitimidade e de estabilidade.

Entretanto, apesar de existir diferentes modelos para o que denominamos de "democracia", um desses formatos se sobrepôs aos demais a ponto de o Ocidente tratá-lo como único modelo viável ou possível (Heywood, 2004).

Não é por acaso que Francis Fukuyama, cientista político estadunidense, chegou a afirmar sobre o que seria o "fim da história". Seu argumento central era o triunfo do liberalismo ocidental, perante todas as outras aparentes alternativas. Nas palavras do autor (1989:1):

Mas o século que começou cheio de autoconfiança no triunfo final da democracia liberal ocidental parece estar voltando para onde o ciclo começou: não para um "fim da ideologia" ou para uma convergência entre capitalismo e socialismo, como anteriormente previsto, mas para uma implacável vitória do liberalismo econômico e político 5 .

A prevalência da democracia nos regimes ocidentais pode trazer a perspectiva ilusória de que democracia e liberalismo estão intrinsecamente interligados.

\footnotetext{
${ }^{4}$ Há várias maneiras de classificar e dividir a teoria democrática em vertentes. Aqui, optou-se por uma classificação semelhante à vista em Miguel, 2005. O foco, porém, é outro, tendo em vista que o objetivo principal dessa revisão de literatura é analisar o papel da desigualdade social nas diversas correntes. É importante esclarecer, porém, que essa classificação ainda tende a ser um tanto reducionista, pois são agrupados autores de diferentes perspectivas na mesma categoria.

5 Tradução própria.
} 
Contrariamente a uma associação imediata, porém, os dois termos possuíram inicialmente uma relação antitética. Tal antítese baseia-se nos dois sentidos contrapostos que possui a palavra "liberdade": para o liberalismo, o termo estaria relacionado às fruições privadas, enquanto, no sentido democrático, liberdade estaria ligada à participação ativa dos indivíduos na esfera política (Bobbio, 1988).

Dessa forma, enquanto o liberalismo implica em uma concepção de Estado em que suas funções e seus poderes são limitados, democracia indicava distribuição igualitária do poder. O pensamento liberal baseia-se, portanto, no individualismo, em que os indivíduos existem anteriormente à sociedade e possui direitos inerentes dos quais não podem ser privados pela instituição política ${ }^{6}$ (Bobbio, 1988).

No que tange especificamente à teoria democrática, a corrente liberal-pluralista compreende as posições que descrevem os sistemas políticos ocidentais, em que o projeto democrático está relacionado a um conjunto de liberdades cidadãs, à competição eleitoral e livre e à multiplicidade de grupos de pressão (Miguel, 2005). Diferentes autores fazem parte dessa corrente, como Anthony Downs e Robert Dahl.

Embora Joseph Schumpeter não seja enquadrado como pluralista, ele teve uma influência significativa nos trabalhos dessa corrente e no pensamento liberal. Influenciado pelo pensamento de Max Weber, que enxergava a democracia como um sistema de mercado, Schumpeter afirma delinear um modelo "realista" da democracia, embora certa dimensão normativa seja inescapável.

Assim, o método democrático da doutrina clássica ${ }^{7}$ é descrito como "o arranjo institucional para se chegar a certas decisões políticas que realizam o bem comum, cabendo ao próprio povo decidir, através da eleição de indivíduos que se reúnem para cumprir-lhe a vontade" (Schumpeter, 1961 [1942]: 305).

\footnotetext{
${ }^{6} \mathrm{~A}$ forma primária do liberalismo surgiu com a queda do feudalismo, em oposição aos antigos privilégios feudais. Assim, o liberalismo era uma doutrina que advogava contra esses privilégios (Heywood, 2004). A luta original do liberalismo era a defesa de uma esfera unicamente privada, independente dos poderes do Estado e da Igreja. Nesse contexto, os indivíduos eram descritos como "livres e iguais", detentores de direitos inalienáveis. Cabe destacar, no entanto, que esses indivíduos se referiam majoritariamente às novas classes médias e à burguesia. De fato, o "indivíduo" do liberalismo em sua origem era o homem, que seguiu, durante muito tempo, como ator predominante na vida pública, sem questionamentos (Held, 2007 [2006]).

${ }^{7} \mathrm{O}$ autor associa a democracia com ideais republicanos modernos, como a busca pelo bem comum e o conceito de vontade geral, agrupando diversos autores que, por vezes, são considerados incompatíveis, como Rousseau e alguns utilitaristas (ver Miguel, 2005). Por outro lado, Pateman (1992 [1970]) argumenta que a existência de uma "teoria clássica da democracia" é um mito e que os autores que utilizam o termo geralmente não explicam o que constitui tal teoria clássica.
} 
A crítica ao que seria esse método "clássico" possui três argumentos principais: a inexistência desse tal "bem comum", a inexistência de soluções igualmente definitivas para casos individuais (pressupondo a existência do bem comum) e a presunção de uma racionalidade irreal por parte dos indivíduos e do povo.

Se o indivíduo atomizado já apresenta esses traços de irracionalidade, a massa de indivíduos é ainda pior, segundo a perspectiva de Schumpeter. Assim, o autor faz uma crítica à atribuição ao eleitorado do poder de decidir sobre questões políticas. A alternativa que ele propõe é justamente uma inversão de papéis: em vez de o povo decidir sobre as questões públicas, ele estaria encarregado de selecionar um governo que decida sobre essas questões.

O conceito de democracia é então reformulado de forma a designar "um sistema institucional, para a tomada de decisões políticas, no qual o indivíduo adquire o poder de decidir mediante uma luta competitiva pelos votos do eleitor" (Schumpeter, 1961 [1942]: $328)$.

O conceito de democracia passa a ser redefinido, passando a compreender um método para gerar uma elite governante. A igualdade política encontra-se reduzida, uma vez que não cabe ao povo decidir sobre as questões, mas delegar essa decisão a um governo selecionado. Há, portanto, uma naturalização da desigualdade política, inerente à democracia de Schumpeter, visto que o povo está privado das decisões públicas, delegadas a uma elite ${ }^{8}$.

O próprio conceito de liberdade, vista como individual e necessária à democracia, não é muito substantivo, uma vez que não são considerados os obstáculos da efetivação dessa liberdade, nos quais poderia (e talvez, deveria) estar incluso o aspecto econômico. Por exemplo, o autor enfatiza a liberdade de candidatura, porém tal liberdade constitui-se em mero aspecto formal, uma vez que as condições reais dessa candidatura não são abordadas.

\footnotetext{
${ }^{8}$ Sob esse aspecto, vale ressaltar que o autor não aparenta estar muito preocupado com a questão dos princípios democráticos, tendo em vista que diz ter a pretensão de "descrever" a realidade ao invés de propor uma alternativa. Todavia, o autor não consegue evitar certa dimensão normativa, pois ao passo que o modelo da democracia concorrencial descreve os regimes ocidentais, ele também confere legitimidade a esses regimes, devido à ligação com o adjetivo "democrático", apesar da distância do original significado do termo (Miguel, 2002).
} 
Assim, na lógica schumpeteriana, a desigualdade não é vista como um obstáculo à democracia, visto que a participação dos cidadãos limita-se a selecionar o governo, que tomará todas as decisões políticas a partir de então. A desigualdade pode até ser vista como necessária, pois a distinção entre governantes (selecionados pelo método eleitoral) e governados pressupõe que os primeiros estão em um nível superior: assim, ao passo que os selecionados são vistos como mais capazes, eles também detém controle maior sobre as decisões e a informação, de maneira geral.

A interação entre igualdade econômica e política e os impactos da concentração de recursos na democracia é negligenciada face à naturalização das desigualdades. Até a suposta incapacidade das massas e sua facilidade de manipulação, descrita pelo autor, parece ter um fundamento mais centrado em atributos psicológicos que em outros aspectos, como as condições materiais. Poderia se argumentar que as massas são mais vulneráveis devido à posição social em que os indivíduos se encontram, mas isso está fora do modelo de Schumpeter.

Dessa forma, se o cidadão médio é menos capaz, isso não é devido à distribuição desigual dos recursos (acesso à informação, por exemplo), mas de sua irracionalidade inata no que se refere aos assuntos políticos. A racionalidade é vista, portanto, como um atributo natural em vez de um construto social.

Também no trabalho de Downs (1999 [1957]) a racionalidade ocupa um espaço fundamental. Na formulação de seu modelo, o funcionamento da democracia é analisado por meio da dinâmica partidária e eleitoral em relação à disputa pelo poder. Nesse contexto, ambos - eleitores e governos - são vistos como atores racionais, que buscam a maximização de sua função de utilidade.

O governo é visto simultaneamente como o lócus do poder político e uma organização especializada, isso é, detentora de uma função especializada na divisão do trabalho. Downs (1999 [1957]: 44) afirma que "é permitido ao governo fazer qualquer coisa que não viole os limites constitucionais", ressaltando-se novamente que isso se trata de uma observação do plano real e não do ideal. A democracia está relacionada às eleições e à dinâmica partidária.

De forma resumida, o governo democrático é descrito, por Downs (1999 [1957]), como detentor das seguintes características: 
i. Um partido (ou uma coalizão) é escolhido para gerir o aparato do governo por meio de eleições realizadas periodicamente, nas quais há dois ou mais partidos competindo;

ii. Todos os adultos podem votar (Downs observa, porém, que há casos em que mulheres e estrangeiros não possuem esse direito);

iii. Cada eleitor tem direito a um voto;

iv. Os partidos perdedores não podem impedir, por meios ilegais, os vencedores de tomarem posse;

v. O partido no poder não pode tentar restringir as atividades políticas de cidadãos ou outros partidos;

Em suma, "um governo democrático é aquele escolhido periodicamente por meio de eleições populares nas quais dois ou mais partidos competem pelos votos de todos os adultos" (Downs, 1999 [1957]: 56).

Dessa maneira, no pensamento do autor, existem três tipos que tomam decisões políticas: partidos políticos, cidadãos individuais e grupos de interesse. Downs (1999 [1957]) baseia-se no axioma do interesse pessoal, em que os indivíduos agem racionalmente para atingir fins egoístas ${ }^{9}$. De acordo com o axioma, o conflito de interesses está na constituição da natureza humana que faz com que os indivíduos sacrifiquem o interesse de outrem em nome do próprio.

Seguindo esses pressupostos, o comportamento racional dos membros partidários é dirigido à motivação central, a qual se constitui na busca por renda, prestígio e poder que resultam do cargo público. Assim, eles estariam buscando as recompensas de estar em um cargo público. Desse pressuposto resulta a lógica de Downs: os membros partidários não buscam políticas específicas, mas como elas afetam a quantidade de votos recebida, acabam se tornando meios de atingir os fins privados.

A hipótese central é que "os partidos formulam políticas a fim de ganhar eleições, e não ganham eleições a fim de formular políticas" (Downs, 1999 [1957]: 50). O voto é classificado como racional, pois os cidadãos votam de acordo com a comparação que

\footnotetext{
${ }^{9}$ Anthony Downs (1999 [1957]) admite a existência de altruísmo na política e chega até a flexibilizar o axioma, porém afirma que as teorias gerais da ação social baseiam-se no axioma do interesse pessoal. $\mathrm{O}$ autor também admite a existência de irracionalidade - quando complementa o modelo simples considerando outros fatores (como a distinção entre sistemas bipartidários e pluripartidários). A própria natureza conflituosa da sociedade é destacada como uma das razões pelas quais existe certo nível de irracionalidade na política, pois os cidadãos não podem atingir todas as suas metas.
} 
fazem da estimativa da renda de utilidade dos partidos competidores (o que está no poder e a oposição). Renda de utilidade, nesse caso, significa o fluxo de benefícios provenientes da atividade governamental.

Essa explicação refere-se ao modelo simplificado. A partir da segunda parte da obra, Downs complementa o modelo com a adição da incerteza. Incerteza, nesse contexto, refere-se à "falta de conhecimento seguro sobre o curso dos acontecimentos" (Downs, 1999 [1957]: 100). A incerteza relaciona-se, portanto, à confiança com a qual os cidadãos tomam suas decisões. São classificados dois tipos de conhecimento: o contextual, que se refere ao conhecimento sobre o campo; e a informação, constituída por dados atuais sobre alguma variável. Ambos, ocasionalmente, podem ser chamados de "informação".

No pensamento de Downs (1999 [1957]), a incerteza transforma a democracia em governo representativo, uma vez que é necessária a existência de intermediários entre o governo e os indivíduos que levem "o que o povo quer" ao governo. É justamente a incerteza que relaciona - na lógica de Downs - a igualdade política, ou mais precisamente a falta dela nos regimes democráticos, à distribuição de renda. Como afirma o autor:

A incerteza permite que as distribuições desiguais de renda, posição e influência - todas as quais são individuais em qualquer economia marcada por uma divisão extensiva do trabalho - compartilhem soberania num reino em que apenas a distribuição equitativa de votos deve reinar (Downs, 1999 [1957]: 114).

Pode-se inferir que a renda ${ }^{10}$ afeta a distribuição do poder político devido à existência de incerteza através de duas formas. Primeiramente, a renda afeta diretamente essa distribuição, visto que "os eleitores com as maiores rendas também têm maior poder político, já que num mundo incerto podem usar seus recursos financeiros para criar influência para eles próprios" (Downs, 1999 [1957]: 220).

Em segundo lugar, a renda afeta indiretamente a distribuição de poder político, pois ela está relacionada com a obtenção de informação. As formas de processamento de dados dependem, em larga medida, tanto da educação formal recebida quanto do trabalho. Em termos de educação, é inegável que os grupos de alta renda possuem certas vantagens. Ademais, a renda está associada ao acesso inicial a canais de informação (mesmo que

\footnotetext{
${ }^{10}$ Renda, aqui, refere-se ao dinheiro e não mais à renda de utilidade (que abrange outros fatores ligados ao bem-estar individual).
} 
posteriormente essa informação seja gratuita) e à informação adquirida através dos contatos, os quais estão relacionados à classe social do indivíduo (Downs, 1999 [1957]).

Sobretudo, votar também implica em certos custos. No modelo formulado por Downs (1999 [1957]), quando esses custos excedem o que seria o retorno da ação de votar, o indivíduo se abstém. Dessa forma, as taxas de abstenções das classes de menores rendas são superiores àquelas das classes que recebem maior renda.

Assim, Downs (1999 [1957]) admite que a necessidade de arcar com custos econômicos para agir politicamente altera a distribuição de poder, porém ele não especifica o quão significante é esse fenômeno. $\mathrm{O}$ autor também considera que governos democráticos tendem a direcionar uma redistribuição de renda dos ricos para os pobres, visto que os pobres são numerosos e o governo age com a finalidade de maximizar votos.

A distribuição de renda distorce o princípio da igualdade política. Todavia, o autor esclarece que mesmo em uma sociedade cujas rendas sejam iguais e o interesse pela política seja o mesmo, os indivíduos seriam diferencialmente bem-informados. Nesse sentido, as bases de poder político diferenciado residem na natureza própria da sociedade. Para Downs (1999 [1957]), a desigualdade é inerente à sociedade democrática, apesar de a igualdade ser sua premissa.

Esse argumento implica na naturalização da desigualdade, semelhante ao pensamento elitista. O perigo maior desse tipo de argumento é o determinismo natural que se torna um entrave à proposta de mudança: uma vez visualizada como natural, a desigualdade deixa de ser objeto da mudança, pois essa mudança é vista como impossível ou pouco provável de ser realizada.

Em uma linha semelhante à de Downs, Robert Dahl (2006 [1956]) afirma que, em todas as organizações humanas, há variações significativas na participação em decisões políticas. No caso dos Estados Unidos, essas variações estariam relacionadas ao envolvimento, à habilidade e ao status socioeconômico, entre outros fatores ressaltados pelo autor.

O autor destaca uma "propensão à passividade política" dos mais pobres, a qual os privaria de seus direitos políticos. Todavia, diferentemente de Schumpeter, ele não atribui essa passividade exclusivamente a uma característica psicológica, mas ressalta a diferença de acesso de ricos e pobres aos recursos organizacionais, financeiros e propagandísticos. 
Ele reconhece que os regimes ocidentais não são exatamente o "governo do povo", mas, por outro lado, nega que exista uma elite do poder (Miguel, 2005). A ausência de uma elite deriva da desconcentração de poder, que garante a estabilidade da democracia, visto que o poder estaria dividido em diversos grupos com interesses distintos, trazendo, assim, equilíbrio para a competição (Marques, 2007).

O conceito-chave é o de "minorias" em vez de "minoria". Na lógica de Dahl (2006 [1956]), o governo democrático se distinguiria de uma ditadura por ser um governo de minorias no plural, em que a tomada de decisões pelo governo ocorre por meio do apaziguamento de grupos pequenos. Ao descrever a configuração da poliarquia, a preocupação central de Dahl (2005 [1972]) é o processo de democratização, ou seja, a transição de um regime para a poliarquia.

O autor decompõe o regime, então, em dois eixos: liberalização, que se refere à contestação pública ou o direito de fazer oposição, e inclusividade, que se constitui no direito de participar. Conforme os regimes se localizem perante os dois eixos, eles podem ser classificados como hegemonias fechadas, hegemonias inclusivas, oligarquias competitivas, ou poliarquia, em que a liberalização e a inclusividade atingem o ponto máximo.

O eixo "contestação pública" inclui diversos direitos liberais, como liberdade de formar (e participar de) organizações, liberdade de expressão, direito de voto e de elegibilidade, competição entre líderes políticos, fontes alternativas de informação, eleições livres e justas, instituições que vinculem políticas ao voto e a outros tipos de expressão de preferências (Tilly, 2006).

Segundo Dahl (2005 [1972]), a contestação pública está relacionada aos custos e aos recursos associados à tolerância e à supressão da oposição no regime. Tais recursos referem-se à coerção ou violência e às sanções econômicas. Nesse sentido, concentração excessiva desses recursos no governo ou na oposição é negativa, pois traz coerção ou instabilidade.

Poderia ser argumentado que já nessa assertiva, Dahl (2005 [1972]) aborda a temática da desigualdade, uma vez que a concentração de recursos é vista como negativa do ponto de vista da poliarquia. Todavia, o autor vai além ao esboçar um modelo que considere a relação direta entre indicadores socioeconômicos de desenvolvimento e o regime poliárquico. 
O autor começa com as sociedades agrárias, em que as desigualdades de status, riqueza, renda e meios de coerção estão relacionadas às desigualdades em recursos políticos. Uma sociedade camponesa tradicional é marcada por fortes desigualdades nessas esferas, diferentemente de uma sociedade de agricultores livres. Assim,

Uma pequena minoria com recursos superiores desenvolve e mantém um sistema político hegemônico (frequentemente encabeçado por um único governante) através do qual ela pode reforçar também seu domínio sobre a ordem social e, com isso, fortalecer ainda mais as desigualdades iniciais (Dahl, 2005 [1972]: 69).

Já as sociedades industriais e comerciais são comumente associadas a uma política mais competitiva, pois o pensamento liberal pressupunha que uma política competitiva exigiria uma ordem social pluralista e uma economia competitiva, remetendo à propriedade privada. No entanto, essa equação é alterada quando a política competitiva exige uma ordem social pluralista, a qual depende de uma economia descentralizada. Dessa maneira, o socialismo poderia manter uma ordem social pluralista (Dahl, 2005 [1972]).

Todavia, as sociedades industriais e comerciais não eliminam as desigualdades, o que levaria ao questionamento sobre como uma poliarquia pode sobreviver nessas situações. $\mathrm{O}$ autor esclarece que tais sociedades modificam o padrão de desigualdades, pois geram maior paridade na distribuição de recursos políticos. Embora a industrialização não gere igualdade, ela diminui as desigualdades extremas de recursos políticos importantes. Assim, apesar de a acumulação de riqueza, renda e status não estar impedida nessas sociedades, a acumulação de recursos políticos é reduzida (Dahl, 2005 [1972]).

Cria-se um sistema de desigualdades dispersas, em que o acesso a um recurso político compensa a falta de acesso a outro recurso. Igualdades e desigualdades afetam as chances de um regime ser hegemônico ou competitivo por meio da distribuição de habilidades e recursos políticos e da criação de frustrações e ressentimentos. A criação de ressentimentos e frustrações pelas desigualdades afeta o comprometimento do grupo prejudicado com o regime, mas as consequências - se positivas ou negativas - dependerão 
da resposta do governo e da percepção que os indivíduos possuem sobre sua própria condição e a de seu país (Dahl, 2005 [1972]) ${ }^{11}$.

É importante lembrar que os atores que possuem influência ou controle sobre o Estado podem utilizar o poder dele em prol de uma reordenação dos recursos políticos inicialmente distribuídos em decorrência dos processos das instituições socioeconômicas (Dahl, 2005 [1972]). A relação entre recursos políticos e econômicos é mais complexa ainda, pois ambos podem se influenciar de forma mútua, gerando um ciclo vicioso.

Poliarquia e nível de desenvolvimento socioeconômico estão relacionados, mas isso não significa que todos os regimes competitivos ou mesmo poliarquias são regimes com alto nível de desenvolvimento socioeconômico, visto que existem casos desviantes. Há, ainda, um problema de direção causal, uma vez que poliarquia e desenvolvimento econômico podem estar relacionados mutuamente (Dahl, 2005 [1972]).

A relação entre os dois pode ser resumida, no entanto, da seguinte forma:

As chances de um país desenvolver-se e manter um regime competitivo (e, mais ainda, uma poliarquia) dependem da medida com que a sociedade e a economia do país:

(a) Forneçam alfabetização, educação e comunicação;

(b) Criem uma ordem social mais pluralista do que centralmente dominada

(c) Impeçam desigualdades extremas entre as camadas relevantes do país (Dahl, 2005 [1972]: 85).

Até então, porém, a desigualdade social ocupava um papel secundário em comparação com a relevância atribuída à presença de oposição no regime democrático. A questão da relação entre igualdade econômica e política é aprofundada de forma mais direta na obra A Preface to Economic Democracy, em que Dahl (1985) propõe uma alternativa ao capitalismo corporativista.

Nota-se, aqui, um deslocamento de prioridade que remete à própria trajetória do autor: o foco foi transferido da estabilidade e da dispersão de recursos políticos para a igualdade e a soberania popular (ver Abu-El-Haj, 2008).

\footnotetext{
${ }^{11} \mathrm{O}$ autor não elimina a existência de um sistema duplo, poliárquico para uma maioria e hegemônico para uma minoria que não detém recursos políticos. Esse foi justamente o caso da Grécia Antiga e do Sul dos Estados Unidos, em que os escravos estavam excluídos da vida política (Dahl, 2005 [1972]).
} 
O capitalismo corporativo é caracterizado pelo controle de firmas e empresas pelos acionistas. Tal controle seria uma fonte de desigualdade política, uma vez que gera diferenças em renda, status, acesso à informação e a líderes políticos, o que contribui para capacidades diferenciadas de participar como politicamente iguais.

A liberdade econômica poderia produzir, portanto, efeitos negativos sobre a igualdade política, visto que ela produz desigualdades em recursos e, consequentemente, no poder. Entretanto, essa tensão entre liberdade econômica e igualdade política depende tanto do conceito de liberdade quanto da própria concepção sobre propriedade privada.

Dahl (1985) mostra que, no republicanismo democrático agrário, a propriedade privada foi justificada pela distribuição igualitária da terra que existia em abundância. A difusão da propriedade privada naquele período propiciou igualdade política, visto que a terra foi distribuída de forma igualitária. A nova ordem econômica se justificou na ideologia precedente, em que o domínio de grandes corporações remeteu à defesa da propriedade privada - mas trouxe, ao invés de igualdade política, muitas desigualdades.

A liberdade econômica é entendida como o direito de perseguir vantagens econômicas pessoais. Assim, há uma dimensão negativa e uma positiva: enquanto ninguém tem o direito de impedir outrem de exercer o direito de adquirir recursos econômicos se houver oportunidade e se essa aquisição não prejudicar o direito de outro, a ordem social e econômica deve garantir que essas oportunidades existam para todos (Dahl, 1985).

A alternativa proposta por Dahl (1985) é uma ordem econômica formada por empresas autogovernadas, dirigidas democraticamente pelas pessoas que trabalham nelas. Essas empresas estariam sujeitas ao controle externo do mercado e das leis e dos regulamentos impostos democraticamente. Essa ordem não seria plenamente igualitária e autorregulada, mas contribuiria para diminuir as desigualdades, principalmente de riqueza e renda, pois a remuneração estaria sujeita às decisões dos próprios trabalhadores (Dahl, 1985).

Nas empresas autogovernadas, os trabalhadores escolhem como as decisões serão tomadas por meio de um processo democrático (como, por exemplo, quais decisões estarão sujeitas à assembleia, se haverá algum corpo distinto que tomará certos tipos de decisões). As desigualdades entre firmas permaneceriam, mas poderiam ser mitigadas por regulação e redistribuição (Dahl, 1985). 
Como as causas das desigualdades díspares são atribuídas à concentração de posse de propriedade e ao pagamento exagerado para executivos no topo da hierarquia, as empresas autogovernadas seriam promotoras de uma distribuição mais igualitária dos recursos econômicos, e, consequentemente políticos (Dahl, 1985). Assim, há uma interação entre recursos econômicos e políticos, em que renda é um dos fatores que afetam a capacidade de participação política.

Porém, tal modelo encontra certas limitações. Primeiramente, o modelo autogestionário não impede que as desigualdades incorporadas nas pessoas se manifestem na dinâmica das relações dentro desses espaços comprometendo o princípio de igualdade política. Um segundo problema é que o modelo se restringe à dinâmica interna das firmas, não abordando outras esferas da sociedade. Dessa forma, a existência de hierarquias e relações autoritárias em outros domínios poderia comprometer o comportamento democrático dos trabalhadores no local de trabalho.

Além disso, a democratização exclusivamente das firmas não garante a democracia em sentido mais amplo. Enquanto Dahl (1985) propõe uma redução drástica das desigualdades advindas do controle da propriedade privada, pouco o autor discute sobre as desigualdades do mercado, mencionando apenas que elas poderiam ser mitigadas por certas medidas de regulação e redistribuição.

Disso decorre que ao adjetivar o capitalismo de "corporativista", Dahl se limita a um aspecto do capitalismo - o controle das empresas pelos acionistas - em vez de discutir uma crítica mais ampla ao sistema capitalista e à reprodução de desigualdades decorrente dele.

Por fim, cabe ressaltar que Dahl (1985) ainda se concentra muito nas "regras", incluindo as de funcionamento das firmas autogestionadas, sem um compromisso mais sólido com a efetividade delas. De fato, a abordagem liberal-pluralista, ao manter o enfoque nas instituições, acaba por negligenciar as condições sociais para que os indivíduos disponham delas.

Assim, a corrente liberal está centrada no aparato institucional, principalmente na dinâmica partidária e eleitoral. As eleições são vistas majoritariamente como forma de autorização e de controle em relação ao governo. O pensamento liberal clássico admitia que os cidadãos possuíam capacidades diferentes para controlar o excesso do governo. Como o conhecimento era uma justificativa para aquisição da propriedade e aqueles que a 
possuíam tinham mais o que perder de um governo corrupto, a mesma classe de cidadãos dominariam ambas as esferas pública e privada (Delli Carpini e Keeter, 1996).

Enquanto Schumpeter (1961 [1942]) restringe a participação popular a uma mera escolha de lideranças políticas, Downs (1999 [1957]) descreve o funcionamento da democracia com base no mecanismo eleitoral, como se as eleições fossem identificadas integralmente com a democracia. No entanto, já foi exposto anteriormente que o método eleitoral é essencialmente oligárquico. Ademais, democracia e a própria política em si não se restringem às eleições, ou mesmo às instituições formais.

Assim, o principal traço dos regimes que se dizem democráticos é a existência de eleições livres, no sentido de que não há violência física ou restrições formais às candidaturas. Outras interferências, estando o uso do poder econômico incluso nelas, podem ter certa relevância, mas talvez não sejam consideradas de forma que o processo perca a sua legitimidade. No pensamento de Schumpeter, por exemplo, a legitimidade do modelo está vinculada ao significado etimológico da palavra "democracia” (Miguel, 2002).

A igualdade política está presente na corrente liberal-pluralista da seguinte forma: conceitualmente na concepção de "desconcentração de poder", que leva à inferência de que a repartição do poder é positiva; e operacionalmente, na exigência de que cada indivíduo tenha direito a apenas uma voto, trazendo a ideia de que todos os cidadãos possuem "pesos" iguais. Porém, ao focar no aspecto eleitoral, uma série de outras fontes de poder político é desconsiderada, inclusive aquelas visivelmente mais suscetíveis ao poder econômico.

A operacionalização do conceito de igualdade política se mostra, portanto, bastante limitada, pois o regime democrático passa a ser associado a um mero método de escolha de representantes. Disso segue que as regras formais, principalmente relacionadas ao funcionamento das instituições políticas, passam a ser o foco dessa vertente. Assim, a questão é se um determinado país tem ou não liberdade de associação, eleições livres e partidos ideologicamente diversificados que competem pelos cargos públicos.

Nesse sentido, como as instituições realmente funcionam - se os cidadãos realmente possuem acesso ao sistema político ou se os partidos representam verdadeiramente os interesses da população - é uma problemática deixada em segundo plano. Sobretudo, condições relacionadas ao acesso de cidadãos e cidadãs à política são deixadas de lado. 
A questão da influência dos recursos econômicos, no entanto, não está plenamente esquecida. O papel do poder econômico está na transferência de recursos econômicos para recursos políticos, em que diferenças de renda, status e riqueza afetam a igualdade política, a qual se constitui no princípio norteador da democracia. Tanto Downs (1999 [1957]) quanto Dahl abordam a questão do acesso à informação, que pode ser afetada pela renda. Todavia, tal aspecto não é profundamente analisado a ponto de trazer um questionamento mais amplo sobre a ordem socioeconômica e as instituições democráticas atuais. ${ }^{12}$

Dahl (1985) é o que mais se aproxima desse aprofundamento ao tratar posteriormente da democratização no âmbito das empresas, o que poderia distanciar essa fase de sua obra do restante dos autores da corrente liberal-pluralista. Ainda assim, a vertente liberal, de forma geral, contrapõe a igualdade com a liberdade, priorizando a última em detrimento do princípio igualitário.

Outras questões relacionadas ao acesso do sistema político por parte dos cidadãos comuns não são abordadas, como o fato de certos grupos estarem sumariamente excluídos da política e a construção social de preferências e interesse. Ademais, a participação popular é vinculada majoritariamente ao momento da eleição dos representantes. De fato, o esvaziamento do conceito de participação popular é uma das principais críticas feitas ao liberal-pluralismo pelas outras vertentes da teoria democrática, como será visto posteriormente.

Vale ressaltar, porém, que o liberalismo é uma corrente heterogênea: o liberalismo crítico, por exemplo, trata de forma mais aprofundada a questão dos recursos econômicos. Entretanto, tal vertente insere-se no debate sobre teorias da justiça, em vez de teorias da democracia propriamente ditas.

\subsection{A Democracia Deliberativa: igualdade e esfera pública}

A democracia deliberativa se apresenta como uma alternativa à vertente liberalpluralista e caracteriza-se por um processo de tomada de decisão calcado na deliberação de indivíduos racionais em fóruns de debate (Marques, 2007). Grande parte dela foi desenvolvida com base no pensamento de Jürgen Habermas, em especial nos conceitos de esfera pública (Miguel, 2005; Marques, 2007).

${ }^{12}$ Embora Dahl (1985) tenha proposto o que seria uma ordem econômica diferente do "capitalismo corporativo", ele foca apenas na questão da posse das empresas e restringindo-se ao contexto dos Estados Unidos, sem questionar, porém, o próprio conceito ocidental de democracia. 
A esfera pública é descrita como "composta de sujeitos privados com opinião própria, o que assegura a possibilidade da contraposição coletiva a decisões discricionárias do poder público" (Souza, 2000: 60).

Habermas (1991 [1962]) traça o desenvolvimento da esfera pública abordando as dimensões "pública" e "privada" desde a Grécia Antiga, em que a pólis comum aos cidadãos livres era estritamente separada da oikos, onde os indivíduos possuíam seu próprio domínio. Dessa forma, a esfera privada estava relacionada com a casa, enquanto a esfera pública constituía-se na discussão. Uma vez que a ordem política residia em uma economia patrimonial escravista, a vida pública dependia da autonomia privada dos cidadãos como chefes de família (Habermas, 1991 [1962]) ${ }^{13}$.

Assim, embora as categorias "público" e "privado" tenham nascido como contraposições, a sobrevivência de uma (vida pública) dependia de requisitos relacionados à outra (autonomia privada). Na Idade Média, ocorre uma fusão entre as duas, pois o feudalismo baseava-se em uma autoridade privada atrelada à posse da terra. Uma esfera pública como um domínio distinto pareceu não existir na Alta Idade Média (Habermas, $1991[1962])$.

A separação entre esfera pública e privada no sentido moderno surge no século XVIII, sob o absolutismo. Nesse período, a forma final da publicidade representativa estava reduzida à corte do monarca e simultaneamente recebia mais ênfase (Habermas, 1991 [1962]).

Dessa forma:

\footnotetext{
"Privado" designava a exclusão da esfera do aparato do Estado, por "público" referir ao Estado que se desenvolvera entrementes, sob o absolutismo, em uma entidade com uma existência objetiva contra a pessoa do governante. $\mathrm{O}$ público (das Publikum, le public), era a "autoridade pública" (öffentliche Gewalt) em contraste com tudo "privado" (Privatwesen) (Habermas, 1991 [1962]: 11) ${ }^{14}$.
}

Assim, a esfera pública oposta ao Estado nasce justamente da desvinculação da imprensa do aparato estatal, passando a fazer o papel de mediadora do público que compartilha coletivamente suas experiências públicas e privadas em um fórum. Com a

\footnotetext{
${ }^{13}$ Não se descarta a existência de esferas públicas anteriormente ao período traçado por Habermas. No entanto, esse capítulo aborda exclusivamente a perspectiva desse autor.

${ }^{14}$ Tradução própria (do inglês).
} 
proliferação dos salões e cafés, devido ao crescimento das cidades, a esfera pública burguesa é institucionalizada (Souza, 2000).

O potencial da esfera pública residiria na constituição de uma força interna à comunicação, que indicaria a desconsideração de fatores como riqueza, poder e prestígio, visto que o argumento se sobrepõe ao aspecto do status social (Souza, 2000). Dessa maneira, "na esfera pública burguesa apenas a força do melhor argumento poderia decidir o resultado dos debates: quaisquer outros recursos (econômicos ou sociais) não deveriam, em princípio, ser tidos em consideração" (Silva, 2001: 122). Nesse sentido, Habermas (1991 [1962]: 34) afirma que "no salão, a mente não estava mais a serviço de um patrão; 'opinião' se tornou emancipada dos laços da dependência econômica"15.

Pode-se argumentar, porém, tal como faz a crítica feminista, que essa desconsideração não é apenas irreal, como pode servir para justificar a exclusão de determinados grupos diferentes em termos étnicos, econômicos ou de gênero em relação ao grupo dominante (Silva, 2001). Assim, seria necessária uma reconstrução do conceito de esfera pública para que a categoria fosse capaz de teorizar acerca dos limites da democracia existente. Ademais, a categoria estudada por Habermas inicialmente correspondia a um tipo específico localizado historicamente: a esfera pública burguesa (Fraser, 1990).

A imprensa - invariavelmente ligada ao surgimento da esfera pública - tornou-se um instrumento dos interesses privados, devido ao interesse comercial (Souza, 2000). Dessa forma, houve um diagnóstico negativo da esfera pública: ela deixou de ser um espaço politizado de construção discursiva e crítica para transformar-se em uma "esfera dominada pelos meios de comunicação de massa, infiltrada pelo poder" (Lubenow, 2007: 104).

A esfera pública se torna, então, um agregado de opiniões individuais e um cenário para que interesses privados desenvolvam legitimidade. A legitimidade ocupa um papel central no pensamento de Habermas, pois a sua necessidade crescente é a grande ameaça ao mundo da vida. A concepção dual de sociedade aponta para a existência de dois domínios diferenciados estruturalmente: o sistema e o mundo da vida. No mundo da vida, ocorrem os processos comunicativos de transmissões culturais (Lubenow, 2007).

\footnotetext{
${ }^{15}$ Tradução própria (do inglês).
} 
A função da esfera pública é garantir a autonomia do mundo da vida perante as pressões do sistema, além da função de integração social. Tal função assume um papel mais ativo perante os complexos institucionais no conceito procedimental de democracia (Lubenow, 2007).

Nesse contexto, a esfera pública para Habermas (1997 [1992]) constitui-se em uma rede adequada para a comunicação de conteúdos, tomadas de posições e opiniões, que se reproduzem através do agir comunicativo. Já a sociedade civil compreende os movimentos, associações e organizações que englobam os problemas sociais captados nas esferas privadas (Habermas, 1997 [1992]).

A questão central para a teoria democrática deliberativa está na legitimidade, para a qual o voto seria insuficiente. Assim, o que sustentaria as decisões do governo seria a deliberação de indivíduos racionais, proveniente de um processo comunicativo anterior à formação de preferências em vez do resultado da agregação de preferências individuais. $\mathrm{O}$ papel da comunicação está na contribuição da opinião pública para o direcionamento do sistema administrativo, embora ele não seja plenamente regido por ela (Faria, 2000).

Um aspecto fundamental na teoria deliberativa de Habermas é a distinção entre o aparato institucional e o que está fora dele. Tal distinção pode ser visualizada na diferença entre espaços institucionais, em que a vontade democraticamente constituída é formada e os espaços extra-institucionais, em que a opinião informal é construída. A inter-relação entre esses dois espaços indica a possibilidade de um governo legítimo (Faria, 2000).

O modelo de Habermas não foca exclusivamente no aparato institucional (políticoadministrativo), nem apenas na sociedade. A análise é feita com base na relação entre os dois. Os procedimentos democráticos legais são vistos como filtros que controlam o acesso dos fluxos comunicativos. As questões que são abordadas no meio institucional são influenciadas pela sociedade civil, que transmite os temas advindos das esferas da vida privada para a esfera pública (Faria, 2000).

Nesse contexto, a esfera pública representa a intermediação entre os setores privados e o sistema político, no qual operam as mudanças desejadas. Dessa forma, é necessário que os problemas sejam levantados por meio da sociedade civil, pois é através dela que eles atingem o aparato institucional, passando antes pela mídia (Habermas, 1997 [1992]). 
A desigualdade é tratada, na teoria deliberativa, de forma indireta. O ideal habermasiano de esfera liberal burguesa pressupunha que as desvantagens econômicas e sociais teriam sido mitigadas, no debate, pela força do argumento. Entretanto, não há evidências que comprovem essa ocorrência e seria difícil de sustentar que recursos econômicos e sociais teriam baixa influência em qualquer debate.

Dessa maneira, no plano real, os debates são desvirtuados pela diferença de poder, status e autoridade, que alteram as capacidades de influência de grupos e indivíduos. Sobretudo, a idealização da esfera pública burguesa se mostra insensível ao problema de exclusão de grupos que estavam ausentes da esfera pública, a exemplo das mulheres e dos trabalhadores (Miguel, 2005).

Um dos postulados do procedimento democrático deliberativo corresponde ao seguinte:

As deliberações políticas abrangem todos os assuntos passíveis de regulação tendo em vista o interesse igual de todos. Isto não implica, entretanto, que certos temas e objetos, tradicionalmente considerados "privados", não possam ser submetidos à discussão. Em particular, aquelas questões que são publicamente relevantes, pois dizem respeito à distribuição desigual de recursos dos quais depende, de fato, o exercício dos direitos de comunicação e participação (Faria, 2000: 51).

O exercício efetivo dos direitos de comunicação e participação depende da distribuição de certos recursos, entre eles o econômico. A existência de fluxos comunicativos que pressionam o aparato político-administrativo não garante, por si só, o acesso dos grupos sociais a esses fluxos, uma vez que eles estão condicionados a essa distribuição de recursos.

Assim, o acesso à participação é condicionado "pela posse de competências específicas que são distribuídas desigualmente" (Marques, 2007: 30). O acesso a recursos econômicos, por exemplo, é anterior à deliberação e constitui-se em uma das características sociais ignoradas pela construção teórica e que seria impossível excluir do processo social (Marques, 2007).

Essas competências interagem entre si, visto que acesso a recursos econômicos pode contribuir para adquirir certas habilidades necessárias ao discurso. A situação de fala ideal é, portanto, ilusória. 
Tampouco a pressão exercida pela opinião pública pode ser vista como fator suficiente de participação popular. Ao passo que Habermas critica o voto como insuficiente para prover legitimidade, a crítica de Joshua Cohen está centrada justamente na dissolução da soberania popular por meio da valorização excessiva das condições excepcionais de influência das associações da sociedade civil. Assim, o discurso informal seria insuficiente para promover uma influência efetiva do cidadão comum na arena política formal (Faria, 2000).

Outro ponto questionável da teoria deliberativa de forma geral é a dicotomia entre sociedade civil e Estado. Essas duas categorias não são necessariamente homogêneas e contrapostas. Pateman, por exemplo, critica a separação liberal de Estado e sociedade civil, pois o Estado está imerso nas associações e práticas da sociedade civil, estando sua suposta imparcialidade comprometida (Held, 2007 [2006]).

Assim, embora se constitua supostamente em uma alternativa ao modelo liberal, a democracia deliberativa ainda não amplia de modo suficiente o escopo da participação popular, restringindo-o à deliberação pública e à pressão do sistema políticoadministrativo. Uma vez que o conceito de democracia, no deliberacionismo, está relacionado ao debate e à pressão do sistema político, a relação entre igualdade econômica e política não é abordada de forma aprofundada, pois o debate é visto como pautado exclusivamente no "melhor argumento".

Entretanto, a própria construção dos argumentos é afetada pelas assimetrias materiais, o que evidencia a insuficiência da abordagem deliberacionista em termos de uma análise das condições econômicas e da posição social dos indivíduos. Nesse sentido, há outras correntes da teoria democrática que enfatizam o papel da participação de forma mais ampliada e a influência da desigualdade, como a democracia participativa e o republicanismo, que serão expostos a seguir.

\subsection{O Republicanismo: liberdade e autonomia}

Tanto a democracia liberal quanto a deliberativa tratam a política como um instrumento. Na deliberativa, porém, esse aspecto surge em menor medida, em que a política é um meio para se atingir o consenso, não se constituindo em um bem em si mesmo (Miguel, 2005). Essa instrumentalidade da política é o foco da crítica do republicanismo cívico ao pensamento liberal e à vertente deliberativa, pois na visão republicana, a política passa a ser vista como um fim em si mesmo (Marques, 2007). 
Dessa forma, são enfatizados o exercício da liberdade, o autogoverno e a cidadania ativa, em que sobressai um conceito de cidadão calcado na experiência ateniense de envolvimento direto dos cidadãos com as questões públicas (Marques, 2007). Na antiga Atenas, cidadania significava participação nos negócios públicos, porém essa perspectiva de cidadania ativa acabou desaparecendo por um período longo de ambas a teoria e a prática políticas, ressurgindo na tradição republicana renascentista (Held, 2007 [2006]).

A lógica de ação política da pólis foi substituída pelo sistema teológico trazido pela visão cristã, cuja preocupação central era a forma com a qual os humanos viviam em comunhão com Deus em vez da forma com a qual eles viviam em uma cidade. Isso não significa que o cristianismo tenha negado todos os valores anteriores à Idade Média. Alguns ideais - tais como a igualdade - mantiveram-se, porém com certas alterações. A igualdade, nesse período, correspondia à igualdade perante Deus e à inexistência de direitos morais ou políticos superiores para alguém (Held, 2007 [2006]).

Entretanto, a igualdade não era um conceito pleno, devido ao nível de subsistência em que se encontrava grande parte da população (Held, 2007 [2006]). A igualdade mantinha-se como princípio, mas, em contrapartida, era limitada substancialmente. Vale ressaltar também que a lógica religiosa seria utilizada, em período posterior, para justificar o poder dos reis em uma base divina. Assim, se os homens eram iguais perante Deus, eles não o eram perante o soberano, a nobreza, e até mesmo o alto clero.

Os ideais republicanos ressurgem com a experiência italiana no estabelecimento de cônsules gestores e, posteriormente, de conselhos para dirigir assuntos judiciais, nos séculos XI e XII. Os conselhos eram compostos por funcionários e estavam presentes em diversas cidades, as quais se tornariam cidades-Estado independentes (Held, 2007 [2006]).

Esses funcionários eram eleitos para governarem por períodos limitados e com responsabilidade perante o conselho e aos cidadãos. No contexto de uma Europa feudal dominada pela autoridade religiosa, essas iniciativas representaram inovações extraordinárias e um desafio ao poder eclesiástico (Held, 2007 [2006]).

Todavia, não se pode afirmar que as repúblicas italianas sejam plenamente convergentes com a democracia. $\mathrm{O}$ conceito de cidadania ainda era muito restrito e o próprio termo "democracia" possuía uma conotação negativa. As contribuições trazidas pela experiência republicana foram as inovações institucionais e o desenvolvimento 
posterior de argumentos em prol da autodeterminação e da soberania popular (Held, 2007 [2006]).

Nesse sentido, a liberdade residia no autogoverno da comunidade política, a qual tinha que prestar contas apenas a ela mesma (Held, 2007 [2006]). Enquanto o liberalismo preocupa-se com a legitimidade do processo, o conceito de liberdade ocupa um espaço central na tese republicana. O pensamento liberal está mais centrado em uma liberdade negativa - entendida como ausência de constrangimentos - em uma visão procedimental da democracia, que não está comprometida com uma participação mais ativa dos cidadãos (Melo, 2002).

Já o republicanismo baseia-se em uma visão de liberdade positiva, em que a cidadania ativa é necessária para assegurar a preservação das liberdades negativas. As liberdades individuais são garantidas devido a certas virtudes em conjunto com o envolvimento na esfera pública. Existe, portanto, o reconhecimento por parte do cidadão de que as liberdades negativas são resultado da busca pelo bem comum, mesmo que à custa do interesse privado (Melo, 2002).

Embora a concepção de autogoverno possa trazer a imagem da democracia ateniense, as ideias iniciais republicanas se inspiraram em Roma. $\mathrm{O}$ modelo romano vinculava virtude, liberdade, glória cívica e o poder militar, além de se mostrar mais estável que a experiência grega. A grandeza de Roma era associada tanto a virtude de seus cidadãos, os quais faziam prevalecer o bem público sobre a busca de interesses privados nos assuntos públicos, quanto ao equilíbrio das suas instituições (Held, 2007 [2006]).

Os cidadãos respeitavam o poder do rei, mas eram livres para cuidar de seus próprios assuntos participando do governo. Sua constituição mista permitia que cada força social exercesse um papel, ainda que limitado, e impedia a formação de facções (Held, 2007 [2006]). Políbio demonstrava essa visão. Entretanto, é irônico notar que suposta estabilidade é exaltada na República romana, a qual apresentava um contexto de grande instabilidade social e clivagens.

Fustel de Coulanges (1830-1889) mostra que Roma, mesmo antes de fundada como cidade, era marcada por distinções e desigualdades. A família, unidade da qual se desenvolveu progressivamente a cidade, já era constituída por níveis hierárquicos, em que existia apenas um chefe. Essa distinção se refletia no aspecto econômico, em que a propriedade pertencia exclusivamente ao chefe da família, ou seja, o pai, que era sucedido 
pelo filho mais velho. A história romana, de forma geral, é permeada por uma disputa entre patrícios e plebeus (Coulanges, 2001 [1877]).

Embora os plebeus tenham alcançado algumas conquistas, como algumas leis a seu favor e posteriormente a criação do cargo de tribunos da plebe ${ }^{16}$, Roma está longe de possuir um ideal igualitário, mesmo no auge de sua República. Assim, a idealização do modelo romano poderia ser vista como uma contradição, visto que a questão da igualdade é importante no republicanismo ${ }^{17}$.

Todavia, o republicanismo não se constitui em uma corrente homogênea e é pertinente, ao menos, fazer uma distinção: entre republicanismo clássico (ou protetor) e republicanismo cívico humanista (ou desenvolvimentista). A existência dessas duas subcategorias indica perspectivas distintas sobre a participação política e o exercício da liberdade. Para o republicanismo protetor, calcado na experiência romana, a virtude cívica possuía natureza frágil e era vulnerável à corrupção, sendo a participação um instrumento para salvaguardar a liberdade pessoal (Held, 2007 [2006]).

Essa perspectiva não se distancia plenamente da tradição liberal, no caráter instrumental da participação. O republicanismo cívico, no entanto, apresenta uma visão totalmente distinta, em que a participação possui valor intrínseco no desenvolvimento dos cidadãos como seres humanos. Enquanto a vertente desenvolvimentista se pautava na Grécia, o republicanismo protetor possuía como influência principal a república de Roma (Held, 2007 [2006]).

Um dos autores proeminentes que influenciaram o republicanismo desenvolvimentista é Jean-Jacques Rousseau (1712-1778), cuja obra destaca a questão da formação de desigualdades. Para Rousseau (1988 [1755]), a desigualdade não faz parte de algo inerente ou natural, mas do processo de desenvolvimento da sociedade e das relações sociais. Segundo o autor, o estado de natureza começa com um estágio inicial cujo primeiro sentimento do ser humano é a existência.

\footnotetext{
${ }^{16}$ Coulanges, 2001 [1877] indica que, no início, os tribunos não possuíam autoridade política, representando mais uma concessão de inviolabilidade a alguns dentre os plebeus que direitos aos plebeus como um todo. Os tribunos, porém, foram tomando cada vez mais liberdades. A plebe tampouco se constituía em um grupo homogêneo, decompondo-se em diversas classes de acordo com os graus de riqueza.

${ }^{17}$ Mesmo uma idealização do modelo grego pode ser ilusória, visto que grande parte dos pensadores da época enxergava a democracia como um regime negativo. Ademais, parte significante da população grega estava excluída da tomada de decisões (ver Finley, 1988).
} 
As relações sociais são notadas apenas a partir do momento em que o surgimento de obstáculos faz com que sejam necessários certos exercícios que implicam na adequação dos seres com si mesmos e uns com os outros. A ideia de consideração, então, destaca-se e cada um pretende ter direito a ela.

O desaparecimento da igualdade ocorre desde o momento em que o homem precisou do auxílio de outro e que se percebeu ser útil a um possuir provisões para dois, introduzindo-se a propriedade e fazendo-se necessário o trabalho. Isso significa que a dependência se intercala com a desigualdade quando uns passam a viver a custa de outros (Rousseau, 1988 [1755]).

De acordo com o pensamento de Rousseau (1988 [1755]), as primeiras regras de partilha surgem da propriedade. O estabelecimento político é então criado de forma a evitar a desordem e originando a sociedade das leis. No entanto, trata-se de um falso contrato social, pois legitima uma relação de dominação do pobre pelo rico, em que o objetivo é a perpetuação da propriedade privada. Nesse estágio, portanto, os homens estariam alienados de sua liberdade, que eles possuíam no estágio inicial.

A instituição da propriedade contribui para que os homens busquem não apenas satisfazer suas necessidades, mas principalmente superar os outros. Em decorrência disso, o "conflito de interesses faz com que cada homem se preocupe em proteger o que é seu e arrebatar o que é de outrem" (Macfarlane, 1970: 31). Os ricos e corruptos teriam garantido suas próprias posições por meio do convencimento dos pobres e miseráveis de que instituições políticas seriam necessárias para garantir a paz e a justiça (Macfarlane, 1970).

Esse seria o contrato social falso, ou "contrato antissocial", pois a sociedade política é instituída "no interesse egoísta (amour-propre) dos ricos, e não no autointeresse (amour de soi) de todos" (Macfarlane, 1970: 31). A fraqueza desses primeiros arranjos gera a designação de magistrados para aplicar a lei e a tirania reina quando eles passam a ser governantes hereditários e arbitrários, atingindo-se o último nível de desigualdade (Macfarlane, 1970).

A incapacidade dos homens reconhecerem sua própria sujeição e a aceitação da privação eram os aspectos mais criticados por Rousseau em relação à tirania. A alternativa seria a construção de uma sociedade que permitisse o desenvolvimento da personalidade individual de cada um dos seus membros de forma harmonizada com os interesses da 
comunidade. O verdadeiro contrato social seria a "alienação total do eu em favor da comunidade" (Macfarlane, 1970: 32).

Nota-se, portanto, que há a prevalência de dois conceitos no trabalho de Rousseau: liberdade e igualdade. A relação entre esses dois conceitos, juntamente com a virtude cívica encarnada no verdadeiro contrato social, é um dos aspectos que o diferenciam da corrente liberal. Para Rousseau, a igualdade e a liberdade naturais são suprimidas devido à introdução da propriedade. Assim, a "instituição de um corpo político só poderia tornar-se legítima quando em troca todos os particulares tivessem artificialmente garantidas a igualdade e a liberdade" (Silva, 1994:54).

Rousseau defendia a ideia de uma democracia assembleísta, em que os cidadãos discutissem e decidissem sobre os assuntos públicos em conjunto. Nesse sentido, a "vontade geral" não representa a agregação dos desejos individuais, mas o bem comum (Held, 2007 [2006]).

Assim como na democracia deliberativa, há o papel da discussão, em que se busca atingir um consenso ou, no pensamento de Rousseau, a "vontade geral". Entretanto, para Rousseau, a vontade geral é preexistente ao processo comunicativo (Miguel, 2005). E diferentemente da teoria deliberativa, a democracia de Rousseau pressupõe que os cidadãos tenham realmente o poder de decidir sobre questões públicas, em vez de a deliberação servir apenas como pressão do aparato administrativo.

De fato, a lógica de Rousseau pressupunha a inexistência da separação nítida entre Estado e sociedade civil, pois a soberania residia no povo. O acesso às condições econômicas desempenhava um aspecto fundamental na medida em que grandes disparidades geravam conflito de interesse e dependência, a os quais impediam a formação de juízos autônomos. Para que os cidadãos pudessem ser livres para desenvolver e expressar suas opiniões, era necessário que eles não sofressem constrangimentos relacionados ao seu sustento (Held, 2007 [2006]).

Embora não defendesse uma igualdade absoluta e não fosse totalmente contra a propriedade privada, o tamanho da propriedade possuía como limite a garantia da segurança material e a independência do juízo do indivíduo (Held, 2007 [2006]). Pode-se inferir, portanto, que certos níveis de igualdade material ou de acesso às condições econômicas são necessários para o exercício da liberdade e da autonomia, que são 
concepções centrais no republicanismo. Assim, ao invés da contraposição clássica forjada pelo liberalismo, igualdade e liberdade estão positivamente relacionadas.

As duas vertentes do republicanismo - cívico (desenvolvimentista) e clássico (protetor) - possuem em comum a priorização do interesse público sobre o privado, seja na expressão da "virtude cívica" como utilizada por Maquiavel, ou na "vontade geral”. Dessa forma,

[...] ambos consideram que tal participação deve ser marcada pelo compromisso com interesses gerais da comunidade, que estão acima dos interesses privados de cada um de seus integrantes. Maquiavel, seguindo os autores clássicos, usa o vocabulário da "virtude cívica". Rousseau está mais próximo da expressão contemporânea, o "bem comum". Num caso como no outro, o substrato é o mesmo, com claro conteúdo normativo. A ação política não pode se resumir à barganha ou ao compromisso entre preferências individuais; ela deve pensar no benefício da coletividade (Miguel, 2005: 20).

A ênfase na igualdade política e econômica é maior, porém, no republicanismo cívico, em que ambas são entendidas como condições para a independência e a liberdade (Held, 2007 [2006]). Dessa forma, certo nível de igualdade econômica é visto como requisito para fomentar a igualdade política, a qual, por sua vez, relaciona-se com a participação cívica dos cidadãos/ãs. Esse civismo está no centro do republicanismo. Nesse sentido, quando Dahl (1985) aborda a questão da propriedade privada, a visão republicana é associada à relação entre recursos econômicos e recursos políticos, a qual indica a necessidade de certa distribuição dos recursos econômicos.

A igualdade novamente, porém, não é plena, perpetuando-se a exclusão de alguns grupos, como as mulheres. ${ }^{18}$ (Held, 2007 [2006]).

\subsection{A Democracia Participativa: socialização e independência econômica}

A crítica à democracia liberal reside não apenas na diminuição do escopo de participação popular, mas também no formalismo do modelo, pois a existência de direitos formais não garante sua efetivação real. Faltaria uma exploração sistemática da forma com

\footnotetext{
${ }^{18}$ Não é por acaso que a crítica feminista traz inúmeras contribuições ao debate sobre teoria da democracia. Alguns exemplos são "O Contrato Sexual”, de Carole Pateman, em que a teoria política é analisada do ponto de vista da subordinação das mulheres pelos homens, e as diversas críticas feitas à distinção entre público e privado e à democracia deliberativa, como em Fraser, 1990.
} 
que as assimetrias de recursos e de poder afetam os significados de liberdade e igualdade nas relações diárias (Macpherson, apud Held, 2007 [2006]).

Assim, a participação ativa de vários indivíduos na vida política e social encontrase limitada devido à carência de uma complexa combinação de recursos e de oportunidades, constituindo-se em um ciclo vicioso (Held, 2007 [2006]). A democracia participativa destaca-se pela tentativa de desenho institucional que efetive os ideais propostos, diferentemente do deliberacionismo e do republicanismo que se limitam a expor normas gerais (Miguel, 2005).

Carole Pateman (1992 [1970]) destaca a contribuição dos teóricos da democracia participativa à teoria democrática como um todo em relação à ênfase dada ao aspecto da participação, cujo papel fora largamente reduzido nas teorias contemporâneas ${ }^{19}$. Nesse sentido, destacam-se Rousseau, John Stuart Mill e G.D.H. Cole como teóricos da democracia participativa (Pateman, 1992 [1970]).

Para Rousseau, o sistema político participativo ideal constituía-se naquele que abrangesse as condições de igualdade e independência econômica e de relação de interdependência entre os indivíduos. Interdependência, nesse contexto, não se contrapõe às condições de igualdade e independência, pois se trata de uma dependência da pólis, em que os cidadãos necessitam da cooperação uns dos outros (Pateman, 1992 [1970]).

Dessa forma, "haveria uma dependência igual por parte de cada indivíduo em relação a todos os outros, vistos coletivamente como o soberano, e a participação independente constitui o mecanismo pelo qual essa interação é reforçada" (Pateman, 1992 [1970]: 36). A igualdade política é efetivada pelo processo de participação, pois a política em que os encargos e os benefícios são distribuídos igualmente é a única aceita por todos. Decorre disso, portanto, que a vontade geral é sempre justa (Pateman, 1992 [1970]).

A participação ocorre na tomada de decisões e contribui para que interesses privados sejam protegidos, enquanto preservado simultaneamente o interesse público. Rousseau, porém, vai além ao tratar dos impactos psicológicos decorrentes das instituições sociais e políticas (Pateman, 1992 [1970]).

\footnotetext{
${ }^{19}$ Pateman (1992 [1970]) chama de teorias contemporâneas aqueles decorrentes da influência de Schumpeter e que enfatizem a questão das eleições e da competição entre elites.
} 
Um aspecto central da democracia participativa é a função educativa da participação política. Por meio da participação, ocorre o aprimoramento de cada cidadão na identificação da vontade geral (Miguel, 2005). Assim, o indivíduo aprende a ligação entre o interesse público e privado, tendo que considerar interesses mais abrangentes que o seu interesse meramente privado (Pateman, 1992 [1970]).

Os interesses privados não se contrapõem ao público devido à interação entre dois conceitos fundamentais na obra de Rousseau: liberdade e controle. A participação na tomada de decisão dá ao indivíduo o controle sobre sua própria vida. No caso de um sistema indireto, esse controle seria sobre os representantes (Pateman, 1992 [1970]). Assim, o indivíduo se sujeita à lei, pois ele mesmo contribuiu para cria-la.

O pensamento de Rousseau refere-se ao contexto de cidades-Estado de proprietários camponeses. John Stuart Mill tenta aplicar essa concepção de participação em uma escala maior, tornando-o um governo representativo, que atua em escala nacional por meio de uma elite capacitada que presta contas aos cidadãos e cidadãs e, em nível local, por arranjos que induzam a comportamentos participativos (Pateman, 1992 [1970]).

Para Stuart Mill, o sufrágio universal constituía-se no grande mecanismo de participação. O direito de voto contribuía para que os cidadãos ou cidadãs ampliassem seu conhecimento do mundo social (Miguel, 2005). Dessa forma, "Mill encara o governo e as instituições políticas, em primeiro lugar e acima de tudo, como educativos no sentido mais amplo do termo" (Pateman, 1992 [1970]: 43).

Todavia, segundo Stuart Mill, para que os indivíduos fossem capazes de participar a nível nacional, por meio do voto, era necessária uma preparação a nível local. A função educativa ocorre, portanto, em um governo popular em pequena escala, com o qual os cidadãos e cidadãs aprendem a exercitá-lo em escala maior. Ele rejeita, porém, o argumento de que a igualdade política é condição para a participação efetiva, como presente no pensamento de Rousseau (Pateman 1992 [1970]).

Outro aspecto importante no pensamento de Stuart Mill é a extensão da participação ao local de trabalho. A indústria é visualizada como um local em que há a oportunidade de aprendizado sobre assuntos da coletividade, assim como o governo local. A sociedade é vista como um conjunto de sistemas políticos caracterizados por estruturas de autoridade, as quais influenciam as qualidades e atitudes psicológicas dos indivíduos 
inseridos nelas. Para fomentar a democracia, seria necessário, portanto, democratizar essas estruturas de autoridade (Pateman 1992, [1970]).

Esse argumento é semelhante ao encontrado em Dahl (1985), quando o autor faz uma reflexão sobre a democratização nas empresas, advogando contra o funcionamento do que ele denomina de capitalismo corporativo. Entretanto, Dahl (1985) não aborda de forma tão aprofundada a função educativa da democracia, o que dificultaria sua inserção na corrente da democracia participativa.

Para Dahl (1985), a democratização das empresas não é vista necessariamente como aprendizado em termos de desenvolvimento de atitudes e capacidades psicológicas, mas como condição devido à interação entre igualdade econômica e política em termos de recursos

Essa interação não é, porém, descartada na democracia participativa, principalmente considerando os trabalhos de Rousseau e de Cole. É importante destacar também que tanto em Dahl (1985) quanto na corrente participativa, a indústria ou o local de trabalho podem ser vistos como potencial lócus da democracia, em que pode (ou mais adequadamente deve) ser exercida a participação de maneira mais efetiva.

Para G.D.H Cole, a indústria constitui-se na associação através da qual se poderia desenvolver a democracia por excelência. Cole possui diversas influências, como Marx e William Morris, mas a principal delas ainda é Rousseau. A sociedade é vista como um conjunto de associações unidas pelas vontades dos membros. Para que o indivíduo possa se autogovernar, essas associações precisam ser livres para decidir sobre seus próprios assuntos, assim como ser iguais em poder político, e seus membros devem ser capazes de participar da tomada de decisões (Pateman, 1992 [1970]).

Cole faz duas críticas ao sistema representativo existente. Primeiramente, ele critica o pressuposto de que o indivíduo pode ser representado como um em vez de ser representado para uma função específica. Em segundo lugar, enquanto o sistema de representação funcional implicaria participação e controle constantes por parte do cidadão e da cidadã, nas instituições existentes o eleitor não faz uma escolha real nem possui controle sobre os representantes (Pateman, 1992 [1970]).

Para o autor, o princípio democrático deveria ser aplicado em todas as esferas de ação popular, em vez de se restringir meramente à esfera propriamente política. $\mathrm{O}$ 
indivíduo aprenderia a democracia por meio da participação em associações locais. A indústria seria uma importante arena de revelação do efeito educativo da participação, pois ela apresenta relações de subordinação e é no trabalho que o cidadão comum dispende grande parte de seu tempo (Pateman, 1992 [1970]).

Atitudes subservientes no local de trabalho gerariam o mesmo tipo de atitude quanto ao sistema político em sentido mais amplo, assim como atitudes democráticas incentivadas no local do trabalho propiciariam atitudes democráticas em escala mais ampla. Tal como Rousseau, Cole também considerava a relação entre igualdade econômica e política, em que uma "quantidade substancial de igualdade econômica" seria condição necessária para a igualdade em termos de poder político (Pateman, 1992 [1970]: 56).

Tampouco o sufrágio era visto como suficiente para promover a igualdade, tanto política quanto econômica. Assim, explica Pateman (1992, [1970]: 56):

Segundo Cole, "a democracia abstrata das urnas" não envolvia uma igualdade política real; a igualdade de cidadania implícita no sufrágio universal era apenas formal e obscurecia o fato de que o poder político era dividido com muita desigualdade. "Os democratas teóricos", dizia ele, ignoravam "o fato de que grandes desigualdades de riquezas e de posição social, que resultavam em grandes desigualdades de educação, poder e controle do ambiente, são necessariamente fatais para qualquer democracia verdadeira, seja em política ou em qualquer outra esfera".

A igualdade de independência - crucial para a participação - só pode ser alcançada por meio da equiparação da posição social. Nesse sentido, Cole propõe um socialismo de guilda (Pateman, 1992 [1970]). Dessa forma, enquanto o problema da relação entre capitalismo e democracia é negado no paradigma liberal, ele ganha destaque na democracia participativa na consideração das desigualdades concretas e da interferência que elas exercem na esfera política (Miguel, 2005).

Outro aspecto interessante é a relação entre participação e crença na democracia. A existência de oportunidades de participação no cotidiano das pessoas afeta a própria crença que elas possuem na democracia e em sua capacidade de influência no sistema político. Se as pessoas encontram-se marginalizadas do processo político ou pobremente representáveis, é mais provável que elas considerem que suas opiniões são de pouca 
importância. Por outro lado, se elas sabem que as oportunidades de participação existem, é mais provável que elas participem mais ativamente (Held, 2007 [2006]).

No geral, a democracia participativa baseia-se na relação entre funcionamento das instituições e qualidades psicológicas, em que instituições e indivíduos não podem ser vistos isoladamente. A principal função da participação é a educativa no sentido de desenvolver as capacidades psicológicas necessárias para o exercício da democracia.

A existência de instituições representativas a nível nacional não é suficiente para classificar um regime como democrático, diferente dos defensores da democracia representativa. O sistema participativo se autossustenta, pois desenvolve as habilidades das quais necessita (Pateman, 1992 [1970]).

Destaca-se, portanto, a exigência de democratização das demais esferas, que não são geralmente visualizadas como propriamente políticas, como a família, a escola e o trabalho. À indústria é concedido um foco maior, pois nela se encontram relações de subordinação, além de que existe a condição de igualdade econômica para a participação igual. Igualdade política, nesse contexto, "refere-se à igualdade de poder na determinação das consequências das decisões" (Pateman, 1992 [1970]: 61-62), em vez da clássica definição liberal da correspondência entre indivíduo e voto (um indivíduo corresponde a um voto).

O resultado "inclui não apenas as políticas (decisões), mas também desenvolvimento das capacidades sociais e políticas de cada indivíduo" (Pateman, 1992 [1970]: 62), semelhante ao republicanismo desenvolvimentista, que também possui como um de seus expoentes Rousseau.

Em suma, os participacionistas contemporâneos advogam em prol de maior amplitude para a participação, que ocorreria por meio da implantação de mecanismos democráticos nos diversos espaços que compreendem a vida humana, tais como a família, a escola e os locais de trabalho (Miguel, 2005).

Dessa maneira, está presente inerentemente uma crítica à própria divisão entre público e privado, presente no liberalismo e no deliberacionismo. Na democracia participativa, os espaços comumente conhecidos como "privados" - por exemplo, a família - são vistos em conexão com a atividade pública. Isso significa que, semelhante ao 
marxismo, defende-se uma mudança nas estruturas rígidas impostas pelo capital privado, pelas relações de classes e outras assimetrias de poder (Held, 2006 [1996]).

Embora tenha promovido contribuições importantes, principalmente acerca da relação entre democracia e desigualdade, a democracia participativa não resolve o problema com completude. Sobretudo, a corrente não soluciona o questionamento acerca da vontade das pessoas de participar, como salienta Held (2007 [2006]).

Entretanto, ao considerar o conceito de democracia como atrelado à participação política, é dado maior foco na interação entre igualdade econômica e política, principalmente no que concerne às capacidades e oportunidades dos indivíduos em relação ao acesso ao sistema político.

Enquanto a igualdade política está relacionada efetivamente à influência nas decisões públicas, a igualdade econômica é necessária para preservar a independência e combater a subordinação.

\subsection{Multiculturalismo e teorias da diferença: a questão dos grupos minoritários}

Apenas ao final da década de 1980, os grupos culturais e os direitos de grupo passaram a ser foco para a teoria política. A emergência de fenômenos como o nacionalismo ou a atração exercida pelo pensamento do comunitarismo foi uma das razões devido às quais cresceu o interesse no papel que os grupos exerciam na teoria e na prática (Spinner-Halev, 2006).

Há uma diferença fundamental aqui em relação ao liberalismo: a ênfase nos grupos. O liberalismo foi constituído desde seus primórdios pelo individualismo, em que embora não fosse negada a possibilidade de existência de interesses de grupos, ao menos a possibilidade de ter direitos era excluída. O sujeito do liberalismo é, portanto, o indivíduo, ao passo que o multiculturalismo inclui os grupos sociais na reflexão política (Miguel, 2005).

De fato o pensamento político de inspiração democrática-liberal é dominado por uma perspectiva racionalista, individualista e universalista. Nesse sentido, o procedimento é visto como a criação de consenso supostamente baseado em um acordo racional. Eis que surge a impotência da visão liberal em captar a natureza do político. Não por acaso, houve uma desorientação geral quanto à multiplicação dos conflitos étnicos, religiosos e 
identitários, os quais haviam sido considerados como algo do passado (Mouffe, 1999 [1993]).

O ideal de imparcialidade é criticado pois expressa uma lógica de identidade que busca reduzir as diferenças em unidade. Essa lógica, no entanto, gera uma dicotomia em vez de unidade, pois para mover particulares para uma única categoria universal, é criada uma distinção entre "dentro" e "fora" (Young, 1990: 99).

Dessa forma, o comprometimento com o ideal de imparcialidade tem consequências ideológicas diversas, como o apoio à ideia do Estado neutro, a legitimação da autoridade burocrática e processos de tomada de decisão hierárquicos e o reforço da opressão por colocar o ponto de vista de grupos privilegiados como uma posição universal (Young, 1990).

A imagem do Estado neutro é um mito, pois diferenças de poder, recursos e acesso geram diferenças nos resultados (Young, 1990). Essa suposta neutralidade do Estado serve, portanto, para mascarar a dominação de um grupo (ou grupos) predominante sobre os demais. No geral, a grande preocupação do multiculturalismo constitui-se na defesa desses grupos excluídos.

O termo "multiculturalismo" pode ter diferentes significados, mas geralmente a ênfase dos multiculturalistas está concentrada nos grupos minoritários (Spinner-Halev, 2006). Em termos de teoria democrática, o multiculturalismo, porém, está mais focado em questões de justiça que de democracia (Marques, 2007). Seu ponto de partida é a observação da existência de diversos grupos e pessoas com valores e estilos de vida distintos convivendo em uma mesma sociedade (Miguel, 2005).

Assim, a atenção voltada aos grupos minoritários justifica-se exatamente devido ao argumento de que a cultura dominante já recebe apoio suficiente do sistema. Dessa forma, dois conceitos fundamentais são "respeito" e "reconhecimento". Embora possua algumas linhas gerais comuns, o multiculturalismo não está livre de divisões. Por um lado, os multiculturalistas liberais enxergam o respeito pelos grupos culturais como instrumento para se alcançar a autonomia individual, a qual se constitui em um objetivo liberal (Spinner-Halev, 2006).

Por outro lado, os multiculturalistas não liberais argumentam que a cultura deve ser respeitada devido ao seu valor intrínseco. Nesse sentido, as culturas possuem valor em si, 
pois são criações humanas importantes para a formação da identidade (Spinner-Halev, 2006).

Will Kymlicka é um dos autores que se inserem no multiculturalismo. Ele refuta a dimensão de universalização dos direitos humanos, defendendo uma complementação com base na "teoria dos direitos das minorias", que estaria relacionada aos princípios liberais de liberdade individual, democracia e justiça social. Esses direitos protegeriam os recursos e instituições dos quais a minoria é dependente de forma a garantir a limitação do poder econômico e político (Marques, 2007).

Entretanto, para Kymlicka, as proteções de grupos não devem ser garantidas a ponto de violar direitos fundamentais ao bem-estar individual. Essa proteção ao bem-estar aconteceria sem a intervenção estatal nesses grupos, pois Kymlicka refusa conceder ao Estado liberal o direito de intervir em grupos não liberais (Spinner-Halev, 2006).

Um exemplo comum do dilema entre bem-estar individual e proteção à cultura pode ser visualizado na tensão entre o direito das minorias culturais e a igualdade de gênero. Nesse sentido, Okin (1999) destaca que argumentos em prol do multiculturalismo negligenciam a esfera privada e consideram grupos como atores monolíticos.

Segundo a autora, a defesa de práticas culturais teria mais impacto sobre as mulheres, pois a maioria das culturas tem como um de seus objetivos o controle da mulher pelo homem. Direitos de grupos constituem-se em "parte da solução", mas também podem exacerbar o problema (Okin, 1999: 22). Dessa forma, deve-se prestar atenção nas desigualdades existentes dentro desses grupos.

Políticas voltadas para necessidades de minorias culturais deve considerar seriamente a urgência de representar adequadamente os membros menos poderosos desses mesmos grupos (Okin, 1999). Anne Phillips (2007), porém, critica a visão de Okin (1999) com base no argumento de que a percepção de cultura como fortemente determinante pode diminuir o papel da agência. De acordo com Phillips (2007), no desenvolvimento do debate, Okin (1999) passou a ser vista como representante de um discurso ocidental que enxerga culturas não ocidentais como quase automaticamente patriarcais.

Phillips (2007) critica, portanto, os estereótipos e demonstra preocupação com as minorias culturais, propondo um comprometimento normativo com o princípio da igualdade e o apoio simultâneo ao multiculturalismo e aos direitos das mulheres. 
Verifica-se que a questão da igualdade possui uma posição fundamental no debate dentro do multiculturalismo. Primeiramente, seria plausível supor uma tensão inicial entre igualdade e respeito à diferença. Todavia, essa igualdade pode ser entendida como formal, ou seja, a garantia de mesmo tratamento perante a lei. Essa igualdade é questionável por duas razões: a formalidade não garante a efetividade no plano real, e é duvidável que o mesmo tratamento possa ser dado a grupos tão distintos.

Assim,

O problema que se apresenta é a manutenção de uma mesma lei e de um mesmo rei para súditos que professam diferentes fés; dito de uma forma atualizada, como garantir a unidade política e a igualdade de direitos para cidadãos cujas origens, crenças e valores fundamentais são tão diversos (Miguel, 2005: 29).

Pode-se relacionar a igualdade formal com a crítica à suposição de imparcialidade por parte do Estado: ao passo que o Estado é considerado imparcial, mas é permeável a alguns interesses em detrimento de outros, a igualdade formal é uma suposição de igualdade que não se realiza, tendo em vista as diversas desigualdades que existem. A necessidade de proteção de alguns grupos pode ser justificativa para o tratamento desigual dos desiguais. A presunção de neutralidade do atual tratamento real apenas corrobora para a manutenção das hierarquias já existentes.

Em segundo lugar, uma crítica ao multiculturalismo advinda do liberalismo argumenta que a igualdade e a privacidade, entendidas como soluções liberais, poderiam resolver demandas multiculturalistas. Isso ocorreria por meio do tratamento igualitário de membros que antes eram excluídos da esfera pública. O termo "multiculturalismo" apenas indicaria uma nova maneira de pensar sobre igualdade em um ambiente mais heterogêneo (Spinner-Halev, 2006). No entanto, a interpretação clássica liberal do conceito de igualdade tem se mostrado insuficiente.

Por fim, pode-se inferir que o debate entre os multiculturalistas inclui dois tipos de desigualdade: a discrepância entre a cultura dominante e os grupos minoritários, a qual gera o tratamento diferenciado que esses grupos recebem e a desigualdade dentro dos próprios grupos.

Devido ao foco no aspecto cultural - refletido em crenças, valores ou padrões de comportamento - seria natural supor que a desigualdade da qual o multiculturalismo trata 
estaria mais voltada ao status. Seria o caso de questionar qual a posição que a desigualdade socioeconômica ocupa em uma teoria que enfatiza conceitos como respeito, reconhecimento e identidade. Teria a igualdade econômica perdido espaço para a busca por reconhecimento?

O trabalho de Fraser (2003) fornece algumas respostas a esse tipo de questionamento, dentro do debate trazido pelas teorias da diferença. Segundo a autora, as demandas por justiça social dividem-se em dois tipos: demandas redistributivas e demandas por reconhecimento. Com o fim do comunismo e a emergência da ideologia do livre mercado, a tendência aparente era a mitigação - se não a extinção - das demandas por redistribuição igualitária (Fraser, 2003).

Nessa nova constelação, os dois tipos de demandas da justiça são comumente dissociados. Em alguns casos, torna-se até uma polarização. Sem embargo, o argumento de Fraser (2003) é que essas antíteses são falsas, uma vez que a justiça requer tanto redistribuição quanto reconhecimento. Redistribuição e reconhecimento estão relacionados, pois se referem a conjuntos de suposições relacionadas sobre as causas e os remédios da injustiça.

Existem, portanto, duas dimensões de injustiça: uma voltada à esfera socioeconômica (ligada à busca pelo igualitarismo) e outra à esfera social ou simbólica (padrões de representação, interpretação e comunicação). Segundo Fraser (2001), embora possuam diferenças, ambas deveriam ser remediadas.

Dessas duas compreensões de injustiça, destacam-se dois tipos de remédios: dentro da esfera socioeconômica, a solução representaria uma reestruturação política-econômica, a qual a autora atribui o nome de "redistribuição"; e na esfera cultural ou simbólica, os remédios se associariam ao termo genérico "reconhecimento" (Fraser, 2001).

Contudo, há muitos grupos que se encontram subordinados em um contexto bidimensional, ou seja, sofrem má-distribuição e falta de reconhecimento em formas em que "nenhuma dessas injustiças é um efeito indireto da outra, mas ambas são primárias e co-originais" (Fraser, 2003: 19) ${ }^{20}$. De fato, a maioria dos casos demonstra ser bidimensional, mesmo que haja uma das dimensões com maior peso. Os eixos de

\footnotetext{
${ }^{20}$ Tradução própria.
} 
subordinação interagem, pois os indivíduos fazem parte de mais de uma coletividade (Fraser, 2003).

A visualização do reconhecimento como justiça aponta para uma questão de status social, em termos de como padrões institucionalizados de valor cultural afetam a capacidade dos atores de participarem como pares. A proposta é mudar instituições e práticas sociais para "desinstitucionalizar" padrões de valor cultural que impeçam a paridade de participação e substituí-los por padrões que alimentem essa paridade. A estima social não é igual para todos/as, mas todos/as devem ter o direito de persegui-la (Fraser, 2003).

A paridade de participação corresponde, portanto, à condição de se tornar um par. Dessa maneira, uma distribuição material que garanta aos participantes independência e "voz" e o respeito e a oportunidade iguais para atingir estima social são condições para que os membros da sociedade possam interagir como pares. A paridade de participação é um pré-requisito para a justiça (Fraser, 2003: 36).

Aqui fica claro que a desigualdade econômica não é totalmente obscurecida pela demanda por reconhecimento, visto que ambas podem estar relacionadas. Algumas formas de dependência econômica e desigualdade impedem a paridade de participação por meio de arranjos sociais que institucionalizam a privação, exploração e grandes disparidades em renda e riqueza. Essas condições impedem que algumas pessoas interajam com outras como pares por negá-las meios e oportunidades (Fraser, 2003).

Status e classe são categorias distintas, porém interagem entre si. Enquanto o status se constitui em uma subordinação subjetiva derivada de padrões culturais institucionalizados, classe refere-se a uma subordinação objetiva derivada de arranjos econômicos que impedem alguns atores de adquirir condições e meios para a paridade de participação. Há, assim, dois tipos de obstáculos à paridade: econômicos e culturais (Fraser, 2003).

Destarte, apenas a redistribuição não é suficiente para resolver todas as formas de subordinação, mas continua sendo um aspecto da mudança social (Fraser, 2003). Sobretudo, se a principal preocupação do multiculturalismo constitui-se nos grupos oprimidos, cabe destacar que a subordinação econômica é um tipo de opressão, que pode gerar, inclusive, outras, devido à sua interação com fatores sociais, políticos, e até culturais. 
Assim, o multiculturalismo traz uma perspectiva aliada à ideia de inclusão política de grupos culturalmente e economicamente marginalizados. O conceito de democracia abordado no multiculturalismo está, portanto, relacionado à voz dos grupos oprimidos. Certo nível de igualdade econômica torna-se, portanto, um requisito para a democracia e a justiça, uma vez que a mitigação de disparidades de renda e riqueza associa-se à paridade de participação.

Para que os membros dos diferentes grupos possam ser tratados como "iguais", é necessário que eles tenham as mesmas oportunidades. E tais oportunidades são, de certa forma, condicionadas pela distribuição de renda e riqueza.

\subsection{Marxismo: a interação entre Estado e Sociedade}

Comumente, o marxismo não é classificado como uma teoria democrática em si, embora tenha inspirado algumas correntes, como a democracia participativa. Sobretudo, a crítica à democracia liberal presente no marxismo pode trazer uma série de contribuições para a definição de um conceito mais substantivo. Na análise do marxismo, há dois elementos que ganham destaque em relação à teoria democrática: a dimensão inclusiva do conceito de ditadura do proletariado no marxismo ortodoxo e a discussão sobre a interação entre Estado e sociedade civil presente no neomarxismo.

Dentro do marxismo ortodoxo, o conceito de ditadura do proletariado - tão negligenciado pelos estudos do campo da teoria democrática - tem relação com a democracia devido a seu aspecto inerente de inclusão. Nesse sentido, cabe destacar que o termo "ditadura" não se refere ao regime oposto à democracia, como o termo corrente veio a significar, mas no sentido romano de um período necessário à estabilização (Tavares, 2014).

Assim, a ditadura do proletariado para Marx representava um período de transição rumo a uma sociedade sem classes. Ademais, o termo "proletariado" indicava não apenas uma classe, mas um tipo de "ser genérico" (ver Tavares, 2014), que representava as camadas mais excluídas da população. Nesse sentido, a ditadura do proletariado seria caracterizada pela inclusão política de grupos marginalizados.

Vale ressaltar, contudo, que o foco da preocupação do marxismo não é a distribuição de riqueza em si, mas a exploração na transferência de trabalho do proletário para o burguês. Essa transferência está no centro da teoria do valor de Marx (1970 [1867]), 
o qual associa a grandeza do valor da mercadoria à quantidade de trabalho socialmente necessária em sua produção. Dessa forma, o foco não está nos rendimentos recebidos pelos indivíduos, mas no mecanismo de reprodução do capital.

No que concerne especificamente à teoria democrática, a crítica central do marxismo à denominada "democracia burguesa" está centrada na discrepância entre o aparato formal e as oportunidades reais. Em outras palavras, isso significa questionar "Podem as pessoas ser politicamente iguais se elas são socialmente desiguais?" Por exemplo, quando o sufrágio tornou-se universal, massas de pessoas adquiriram oportunidades em termos de procedimento, mas sem as condições necessárias para efetiválo (Przeworski, 2009).

Ao considerar democracia como distribuição igualitária do poder político, como é a proposta desse trabalho, outro elemento abordado pela vertente marxista torna-se central ao estudo: as relações entre sociedade e Estado. Tal característica - que engloba desde movimentos sociais e ao relacionamento dos diversos segmentos da sociedade com a burocracia - é fundamental na compreensão do regime democrático, pois denota a permeabilidade do centro do poder político aos diversos cidadãos que compõem a sociedade.

Nesse sentido, é preciso analisar o conceito de "seletividade" de Offe (1984 [1972]) e de "permeabilidade" de Poulantzas (2000 [1978]). Segundo Offe (1984 [1972]), a dependência do Estado em relação ao investimento privado é tão grande que os interesses capitalistas são injetados na tomada de decisões. Destarte, haveria uma dependência estrutural do Estado capitalista, uma vez que estaria presente uma seletividade das instituições políticas, as quais são formalmente igualitárias.

O pressuposto da neutralidade estatal é questionado com base na porosidade do Estado para demandas capitalistas. De acordo com o autor, os critérios para identificação do caráter classista do Estado estão no desenvolvimento de uma seletividade que sirva à unificação e à destilação de um interesse "capitalista global" e na seletividade complementar que protege o capital global contra interesses anticapitalistas (Offe, 1984 [1972]).

Os mecanismos de seleção - encontrados na estrutura, na ideologia, no processo e na repressão - compõem um sistema de filtros, cujo resultado é "determinado pelas operações cumulativas de seleção deste sistema" (Offe, 1984 [1972]: 151). Já Poulantzas 
(2000 [1978]) analisa a distribuição de cargos relacionada a grupos econômicos no âmbito do Estado. Nesse sentido, o Estado é visto como uma condensação material de uma relação de forças entre classes e frações de classe.

Poulantzas (2000 [1978]) critica as teses do Estado-coisa e do Estado-sujeito, pois para ambas o Estado seria visto como um ator monolítico. Segundo Poulantzas (2000 [1978]), essas teses não levariam em consideração as contradições internas do Estado. Em contraste, o estabelecimento da política do Estado é considerado como resultante das contradições de classe inseridas na própria estrutura do Estado. Isso significa que cada ramo do Estado constitui-se em sede do poder de interesses particulares ou aliança de interesses.

Paradoxalmente, são essas contradições na materialidade do Estado que torna possível sua função de organização. A política atual do Estado é vista como resultado dessas "contradições interestatais entre setores e aparelhos de Estado e no seio de cada um deles" (Poulantzas, 2000 [1978]: 136). A autonomia relativa do Estado não advém de sua capacidade de se manter exterior às frações do bloco no poder (como o pressuposto da neutralidade estatal poderia supor), mas é resultante do que se passa dentro do Estado, caracterizado por um "jogo de contradições".

Dessa maneira, a "autonomia do Estado em relação a tal ou qual fração do bloco no poder existe pois concretamente como autonomia relativa de tal ou qual setor, aparelho ou rede do Estado em relação aos outros” (Poulantzas, 2000 [1978]: 138). Há a hegemonia de uma classe ou fração no próprio seio do Estado. Isso implica em certa unidade de aparelho (centralismo), a qual se traduz em sua política global em favor da classe ou fração hegemônica (Poulantzas, 2000 [1978]).

A predominância dos interesses da classe dominante sobre os outros se cristaliza por meio da dominação de um aparelho ou setor do Estado. Nesse contexto, o poder é definido como a capacidade de uma ou mais classes sociais em conquistar seus interesses específicos, denotando relações de força. O campo do poder é, portanto, estritamente relacional: o poder de cada classe é designado e delimitado pelo lugar das outras classes. $\mathrm{O}$ poder não é qualidade inerente a alguma classe, mas depende e provém de um sistema relacional de lugares materiais (Poulantzas, 2000 [1978]).

O poder político é fruto da organização de poder de uma classe e a posição de classe na conjuntura. A correlação de forças implica em observações importantes na 
temática que envolve a permeabilidade do Estado a frações exteriores às classes dominantes. Poulantzas, 2000 [1978] admite a existência de classes populares no Estado, as quais se constituem em focos de oposição ao poder das classes dominantes.

Porém, não há poder dual: o arcabouço material do Estado aponta mecanismos internos de reprodução da relação dominação-subordinação. O "pessoal do Estado", mesmo que constitua uma categoria social com unidade própria, não deixa de deter um local de classe e é dividido. Essa categoria - que não constitui em grupo social à parte - é afetada apelas contradições e divisões no seio do bloco do poder e pelas lutas populares (Poulantzas, 2000 [1978]).

Pode-se extrair certa "lição" aos movimentos revolucionários da obra de Poulantzas: em um contexto em que ambos Estado e sociedade são vistos como arenas de luta, não basta "tomar" o Estado, torna-se imperativo lutar dentro e fora dele. A ascensão das massas não poderia se restringir à tomada do poder - embora necessária - pois seria necessário também transformar os aparelhos estatais.

Dessa maneira, o pensamento marxista constitui-se, predominantemente, em uma crítica à democracia burguesia, em que são destacadas as oportunidades "reais" de efetivação desse regime em comparação com os aspectos meramente formais advindos do liberalismo. Em que pese não haver sistematização maior do que seria uma teoria democrática do marxismo, a corrente traz uma série de contribuições para a construção teórica do que seria uma "verdadeira" democracia.

No que tange novamente à teoria democrática, os conceitos de seletividade e permeabilidade podem trazer contribuições substantivas. Primeiramente, é destacada novamente a questão do acesso: seletividade e permeabilidade estão relacionadas ao acesso dos cidadãos e cidadãs ao sistema político, encarnado na figura do Estado. Assim, democracia associa-se à influência política que os cidadãos e cidadãs são capazes de exercer. Se essa influência é díspar para uns grupos em detrimento de outros, a democracia está comprometida, visto que há um estado de desigualdade política.

Em segundo lugar, diferente da proposta do deliberacionismo, a sociedade civil e o Estado deixam de ser vistos como atores monolíticos. Considerar a heterogeneidade de ambos é fundamental no entendimento da relação de grupos e indivíduos com o Estado. Assim, é preciso considerar que o Estado não é um ator homogêneo e que atores podem fazer parte tanto da sociedade quanto do aparato estatal. 
Por fim, os conceitos de permeabilidade e de seletividade podem trazer respostas à abordagem pluralista em relação à fragmentação do poder. Na perspectiva de Dahl sobre desagregação do poder, a desconcentração se justifica pela dispersão do poder em diversos grupos que atuam na política. Entretanto, se a permeabilidade desigual do Estado a certos grupos é considerada, constata-se que o poder não está dividido entre múltiplos grupos, como acreditava Dahl, mas entre um número ainda pequeno de grupos em comparação aos que ainda estão excluídos do sistema político.

Dessa maneira, o poder é fragmentado, mas entre frações de classe dominante que possuem acesso a uma série de recursos e oportunidades necessárias ao exercício da atividade política. Disso decorre que analisar a discrepância entre a influência política direta exercida por determinados grupos que detêm recursos econômicos é fundamental na compreensão das falhas encontradas nos regimes democráticos no que tange à participação política desigual.

\section{8 $O$ debate sobre modernização: mecanismos entre distribuição de renda/riqueza e democratização}

O debate sobre modernização estava centrado não na qualidade do regime democrático em si, mas nas condições que propiciaram a democratização, entendida como processo. Ainda assim, a discussão é importante, pois ao analisar a suposta correlação entre desenvolvimento e democracia, o debate sobre modernização entra na reflexão sobre possíveis mecanismos entre fatores socioeconômicos e regime democrático.

De forma geral, a teoria da modernização sustentava a hipótese de que o desenvolvimento econômico seria condição para a sustentação do regime democrático. Por modernização, entende-se o processo de industrialização e as mudanças que o acompanharam, como a urbanização e o desenvolvimento educativo (Fleury, 2006). A relação entre democracia e desenvolvimento, porém, não está livre de controvérsias. Enquanto os argumentos de uns autores levam a um conceito de "evolução política", outros criticam essa noção de desenvolvimento quase linear.

Lipset foi um dos primeiros a estudar sistematicamente a suposta relação entre desenvolvimento socioeconômico e democracia. Seu estudo acabou tornando-se um conhecimento amplamente aceito. Entretanto, é uma análise geralmente mal interpretada, pois há uma tendência em reduzir o desenvolvimento ao aspecto econômico, em termos da 
correlação entre renda per capita e democracia. A teoria do autor, porém, abrange diversas outras dimensões, como industrialização, urbanização, riqueza e educação, as quais ele descreve como "condições" e não necessariamente causas (Wucherpfennig e Deutsch, 2009).

O próprio autor descreve o objeto do estudo como dissecar as condições da democracia em variáveis inter-relacionadas. Nesse sentido, a democracia é definida como um sistema político que oferta oportunidades constitucionais regulares para mudar os governantes. Na abordagem de Lipset, esse mecanismo possibilitaria que maior parte possível da população influenciasse as decisões por meio da habilidade em escolher entre alternativas concorrentes para o ofício político (Lipset, 1959).

As duas características consideradas em relação à democracia estável são o desenvolvimento econômico e a legitimidade. Dessa forma, Lipset (1959) aponta a tendência da relação positiva entre desenvolvimento e democracia, porém sem descartar a existência de impactos de fatores históricos nos resultados. A preocupação é com as condições sociais que servem para apoiar um regime político democrático, sem lidar com a manutenção dele (Lipset, 1959).

Na perspectiva de Lipset (1959), desenvolvimento econômico está associado à democracia devido a um mecanismo relacionado com as classes sociais. Os países desenvolvidos apresentam índices mais altos de riqueza, educação, urbanização e industrialização. Tais fatores contribuíram para o crescimento da classe média, a qual teria posições políticas mais moderadas. Por outro lado, uma sociedade dividida entre uma massa extensa e empobrecida e uma elite privilegiada resultaria em uma oligarquia (ditadura do estrato superior) ou tirania (ditadura popular).

Dessa maneira,

A riqueza diminui os estorvos tanto públicos quanto particulares e facilita a acomodação social. A educação faz aumentar o número de profissionais qualificados e o grau de sofisticação dos cidadãos. O crescimento econômico incrementa a classe média, baluarte da democracia estável e eficaz. A estabilidade da democracia decorreria, pois, das transformações realizadas na estrutura social pelo avanço da modernização [...] (Fleury, 2006: 27).

O mecanismo causal que relaciona desenvolvimento à democracia, tal como descrito por Lipset (1959), pode ser resumido no quadro abaixo: 
Quadro 1 - Mecanismo causal descrito por Lipset (1959)

\begin{tabular}{|l|l|l|l|l|l|}
\hline $\begin{array}{l}\text { Desenvolvimento } \\
\text { Econômico }\end{array}$ & $\begin{array}{l}\text { Mais renda } \\
\text { para estratos } \\
\text { menos } \\
\text { abastados da } \\
\text { população }\end{array}$ & $\begin{array}{l}\text { Mais } \\
\text { segurança } \\
\text { econômica }\end{array}$ & $\begin{array}{l}\text { Mais } \\
\text { educação }\end{array}$ & $\begin{array}{l}\text { Perspectivas ao } \\
\text { longo prazo: visão } \\
\text { mais complexa da } \\
\text { política (menos } \\
\text { receptividade a a } \\
\text { ideologias } \\
\text { extremistas) } \\
\text { uma cultura nacional } \\
\text { integrada (ao invés de } \\
\text { isolamento): } \\
\text { exposição aos valores } \\
\text { da classe média }\end{array}$ \\
& $\rightarrow$ & $\rightarrow$ & & \\
\hline
\end{tabular}

Fonte: elaboração da autora.

Assim, o papel da classe média é o de moderar o conflito por meio da recompensa aos partidos moderados ou democráticos e da penalização dos grupos extremistas. De acordo com Lipset (1959), os conflitos exacerbados levariam à desintegração. Uma democracia estável requer tensão moderada entre forças políticas.

Assim, a incorporação da classe trabalhadora ao sistema político trouxe mais moderação (Lipset, 1959). Seguindo esse argumento, a combinação entre redistribuição e cidadania fez com que os trabalhadores não empreendessem esforços revolucionários (Wucherpfennig e Deutsch, 2009).

A renda nacional estaria também relacionada aos valores políticos, que se referem ao modo como as classes mais abastadas tratam os estratos "inferiores" economicamente. Se as classes mais abastadas enxergam os outros estratos como inerentemente inferiores, elas rejeitam a democracia e intensificam, por consequência, reações mais extremistas das classes "mais baixas" (Lipset, 1959).

Ademais, o nível geral de renda influenciaria a receptividade às normas políticas de tolerância (Lipset, 1959). A modernização aumentaria a receptividade aos tipos de normas que mitigam o conflito (Wucherpfennig e Deutsch, 2009). Segundo Lipset (1959), quanto mais riqueza, haveria uma tendência maior às normas universais, o que estaria relacionado a uma burocracia mais eficiente.

A riqueza estaria relacionada, ainda que menos diretamente, à presença de organizações intermediárias, as quais exercem um poder compensador em relação ao Estado. Indivíduos que atuam nessas organizações teriam uma tendência maior a participar (Lipset, 1959). 
Esse argumento está presente no estudo de Verba, Schlozman e Brady (1995), que mostram a importância das instituições não políticas na aquisição de capacidades necessárias à atividade política. Destarte, a atuação dos cidadãos em outros tipos de atividades e esferas de socialização, como escolas, o núcleo familiar ou até mesmo instituições religiosas, possui grande influência no envolvimento cívico deles com a política.

Dessa forma, a socialização é um fator importante relacionado à participação política. Desigualdades no acesso a esses espaços - escolas e instituições religiosas, por exemplo - implicam, portanto, em uma desigualdade de participação e, consequentemente, na influência exercida nas decisões públicas.

Lipset (1959) ainda salienta que a combinação entre renda e oportunidade de lazer determina o nível de educação dos indivíduos, o que, por sua vez, está relacionado à participação desses tipos de grupos e organizações. O autor (1959: 85) afirma que:

Desde que sabemos que, dentro de países, quanto mais próspero e mais educado um indivíduo é, é mais provável que ele participe de organizações voluntárias, parece provável que a propensão a formar esses grupos é uma função do nível de renda e oportunidades de lazer dentro de nações determinadas $^{21}$.

A importância da igualdade estaria, portanto, nas condições sociais que nutririam uma cultura democrática. A igualdade econômica estaria relacionada a uma democracia efetiva (Wucherpfennig e Deutsch, 2009).

Seguindo o trabalho de Weber, Lipset (1959) analisa o grupo de condições que marcaram o desenvolvimento dos regimes políticos europeus: desenvolvimento econômico, protestantismo, monarquia, mudança política gradual, legitimidade e democracia. Nesse sentido, o desenvolvimento capitalista determinou o surgimento da burguesia, a qual foi uma condição necessária para a democracia. $\mathrm{O}$ alinhamento da burguesia com o trono teria preservado a monarquia e facilitado a legitimação da democracia (Lipset, 1959).

Nesse contexto, destacam-se dois conceitos fundamentais: efetividade e legitimidade. Efetividade significa atender às expectativas da maior parte da sociedade e

\footnotetext{
${ }^{21}$ Tradução própria.
} 
dos grupos poderosos, enquanto legitimidade refere-se à capacidade de manter a crença de que as instituições políticas são as mais apropriadas. Há, portanto, uma relação entre estrutura social e formas políticas. Nesse sentido, a estrutura social e econômica da América Latina teria contribuído para que o continente não desenvolvesse a "aura" e os símbolos da democracia (Lipset, 1959).

Esse determinismo pautado no contexto europeu constitui-se em um dos focos das críticas às teorias da modernização. Algumas delas, desenvolvidas a partir de 70, chegaram à conclusão de que não havia um nível determinado de desenvolvimento econômico que se constituísse em condição para a democracia. Outros estudos, por outro lado, focavam na oposição à visão de uma via única para o capitalismo (Fleury, 2006). Um desses estudos é o de Barrington Moore.

Por meio de uma análise histórica, Moore argumenta que o desenvolvimento socioeconômico não se traduz necessariamente em caminhos para a democracia. $\mathrm{O}$ autor destaca três rotas para o mundo moderno derivadas do período de industrialização e da estrutura social no período de transição: democrática liberal, fascista e comunista (Wucherpfennig e Deutsch, 2009).

A primeira rota - democrática liberal - corresponderia às sociedades inglesa, francesa e estadunidense. Esses casos seriam marcados pelo desenvolvimento de um grupo com base econômica independente. Assim, a classe agrária e o campesinato foram partes importantes ou foram colocados de lado conforme esforços políticos tenham convergido ou não com capitalismo e democracia (Moore, 1974 [1966]).

Já a rota para o fascismo seria marcada pela derrota da revolução, quando existente. A classe industrial ou comercial, a qual se mostrou relativamente fraca nesses casos, teve que confiar em elementos da velha classe dominante, ligada a terra. Assim, após período curto de democracia instável, o resultado foi o fascismo. Por fim, na rota relacionada ao comunismo, as burocracias agrárias teriam inibido os impulsos industriais (Moore, 1974 [1966]).

Destarte, nota-se que cinco fatores seriam determinantes para a configuração das rotas citadas:

i. Distribuição de poder entre elites;

ii. Base econômica da classe agrária; 
iii. Constelação de classe;

iv. Distribuição de poder entre classes; e

v. Autonomia do Estado em relação à classe dominante (Wucherpfennig e Deutsch, 2009).

Para Moore, a relação entre classes se constituía em elemento central na adoção de uma das vias de modernização existentes. No caso do capitalismo liberal, seria a via em que a burguesia conduziu o processo de forma hegemônica. Uma aliança reacionária entre classes agrárias e burguesia tenderia ao fascismo, enquanto a predominância do campesinato levaria ao comunismo (Fleury, 2006).

O foco de Moore (1974 [1966]) é o papel da classe agrária e do campesinato, em que as formas com as quais ambos lidam com agricultura comercial é a causa do resultado político. O conceito de democracia está associado ao esforço contra regras arbitrárias e à existência de certa parcela de participação no processo de construção das leis.

As condições para o desenvolvimento da democracia seriam o desenvolvimento de equilíbrio para evitar uma coroa muito forte ou uma aristocracia agrária muito independente, a virada em direção a uma forma mais apropriada de agricultura comercial, o enfraquecimento da classe agrária; a prevenção de uma aliança burguesia-aristocracia contra camponeses trabalhadores e a ruptura revolucionária com o passado (Moore, 1974 [1966]).

Embora seja ressaltado o papel da classe agrária e do campesinato nas três rotas, a classe média - encarnada nos moradores das cidades - destaca-se como protagonista no crescimento da democracia parlamentar.

Destarte, apesar das diferenças, tanto Lipset e Moore concordam em relação à classe média como condição necessária. Dentro do debate presente nas teorias da modernização, o mecanismo geral que liga desenvolvimento econômico à democracia é a classe média. O crescimento da classe média, nesse contexto, estaria relacionado a mais demandas de participação e menos conflito (Rueschemeyer, Stephens \& Stephens, 1992).

Entretanto, Rueschemeyer, Stephens e Stephens (1992) argumentam que não é a existência de uma larga classe média em si que determina a relação entre desenvolvimento e democracia, mas as condições de classe e, por consequência, o fortalecimento da sociedade civil. Os autores mostram que as classes médias não são necessariamente 
inclusivas em relação às classes trabalhadoras: elas demandariam inclusão para elas mesmas e se aliariam às classes trabalhadoras quando necessário para que essa inclusão fosse conquistada.

Segundo Rueschemeyer, Stephens e Stephens (1992), Moore teria negligenciado justamente o papel das classes trabalhadoras na democratização. Na análise dos autores, a classe social ainda possui um papel fundamental, porém com diferente enfoque: não é a existência de uma classe em si que é ressaltada, mas o balanço do poder de classe. Assim, a democracia teria sido colocada na agenda devido ao esforço da classe trabalhadora em participar do governo. Dessa forma, foram as próprias contradições do capitalismo que avançaram a causa da democracia (Rueschemeyer, Stephens e Stephens, 1992).

Uma vez que a industrialização enfraquece a classe detentora de terras e fortalece a trabalhadora, poderia existir uma relação positiva entre desenvolvimento e democracia (Wucherpfennig e Deutsch, 2009). O desenvolvimento capitalista aumenta as massas urbanas em detrimento dos trabalhadores rurais, mudando o ambiente dos trabalhadores para um mais favorável à ação coletiva.

Dessa forma, a relação entre desenvolvimento e democracia ocorre por duas razões estruturais: ao passo que o desenvolvimento fortalece a classe trabalhadora e outras subordinadas, a classe detentora de terras é enfraquecida. Entretanto, a classe trabalhadora geralmente não é suficientemente forte para alcançar o regime democrático sem alianças. (Rueschemeyer, Stephens e Stephens, 1992).

Usualmente, essa aliança ocorre com classes anteriormente excluídas. Na América Latina, por exemplo, houve um papel predominante da classe média empregada, mas foi necessária certa autonomia em relação aos interesses dominantes (Rueschemeyer, Stephens e Stephens, 1992).

De acordo com os autores, há uma tensão entre democracia e desigualdade social: em uma sociedade dividida entre classes, muitos possuem menos renda e riqueza, menos educação, honra e poder que uma minoria numérica. A condição mínima da democracia seria uma diferenciação entre instituições da esfera política e o sistema de desigualdades na sociedade, embora essa diferenciação não seja suficiente para eliminar totalmente a influência das desigualdades no domínio político (Rueschemeyer, Stephens e Stephens, 1992). 
Nesse contexto, é necessária certa autonomia do Estado em relação às classes dominantes, principalmente os senhores de terras. Por outro lado, se o Estado for forte demais, pode acabar se tornando fechado às classes subordinadas, o que seria negativo para a democratização (Rueschemeyer, Stephens e Stephens, 1992). A questão da autonomia estatal não pode ser entendida, porém, meramente como uma dicotomia pura entre força do Estado e democracia.

Além disso, a relação entre o aparato estatal e as classes ocorre por meio do recrutamento de altas posições e do "espírito" do corpo de servidores públicos. Ademais, o capitalismo pressupõe uma dependência dos detentores de capital (Rueschemeyer, Stephens e Stephens, 1992). Tal visão assemelha-se à de Offe (1984 [1972]), que trata da dependência do Estado em relação aos capitalistas devido ao controle do investimento.

A contradição clássica entre liberdade e igualdade é novamente questionada. Segundo os autores, não é a magnitude das atividades estatais que se constitui em ameaça para a democracia, mas a construção de um poder coercitivo insuficientemente controlado e o crescimento do Estado sem a contraposição da sociedade civil. Uma condenação a qualquer tipo de intervenção estatal com base na existência de supostos efeitos negativos para a democracia seria, portanto, inadequada.

A democracia, por sua vez, apenas se torna real se é baseada em mudanças significativas na distribuição geral do poder. Em relação à democratização, os autores consideram três fatores: a construção social dos interesses de classe, a persistência de formas organizacionais, alianças e orientações ideológicas e as percepções de oportunidades ou ameaças futuras.

A construção social dos interesses de classe corresponde à forma com a qual os interesses de classe são socialmente produzidos. Nesse sentido, um exemplo seria a hegemonia dos senhores de terras em relação às classes subordinadas por meio da igreja ou a cooptação das classes trabalhadoras por governos populistas.

Vale destacar, porém, que nada garante que posturas serão compatíveis com interpretação dos interesses de classe feita por observadores externos. Tal reflexão retoma a discussão sobre produção social das preferências políticas feita anteriormente e destaca a importância da socialização dos indivíduos no fomento a uma cultura democrática, a qual depende de estruturas passadas e presentes de poder, segundo os autores. 
Já a percepção de oportunidades ou ameaças futuras baseia-se na visão das elites e de como o sentimento de ameaça pode afetar o apoio delas ao regime democrático. Quando as elites não se sentem suficientemente protegidas pelo aparato institucional - cujo foco em questão é o sistema partidário - ou percebem seus interesses ameaçados pela democratização, é mais provável que recorram a outros meios, como a intervenção militar.

De fato, a intervenção militar foi muito comum na região da América do Sul devido ao histórico de guerras de independência e proteção das fronteiras, o que contribuiu para o fortalecimento das Forças Armadas.

Sobretudo, a fragilidade da sociedade civil e a ausência de partidos fortes aos quais as elites possam recorrer contribuem para que esses setores apelem aos militares. Dessa forma, institucionalização refere-se à proteção dos interesses das elites mediante sistema partidário. Isso corrobora a necessidade de um partido político forte que defenda os interesses das elites para a consolidação do regime democrático.

Essa necessidade de proteção dos interesses das elites constitui-se, portanto, em um paradoxo: a "estabilização da democracia formal parece requerer restrições sérias a uma democracia substantiva devido à necessidade de proteção dos interesses da elite" (Rueschemeyer, Stephens e Stephens, 1992: 269) ${ }^{22}$. Ora, se uma democracia substancial é definida em torno da distribuição igualitária de poder político, a própria existência de uma proteção diferenciada dos interesses da elite seria um entrave ao regime democrático.

De acordo com os autores, a democratização exigiria que questões ligadas à igualdade política não entrassem na agenda ou não se tornassem políticas, devido à necessidade de proteção dos interesses da elite. Os autores acreditam que o ideal democrático em termos de completa igualdade política jamais será realizado, embora progresso em direção a maior igualdade política e justiça social substantiva seja possível.

Dessa forma, embora tragam a discussão sobre reprodução de desigualdades na esfera política, a operacionalização do conceito de democracia aqui adotado ainda é estritamente formal. Os seguintes fatores são considerados por Rueschemeyer, Stephens e Stephens (1992): eleições livres e justas (sufrágio universal), responsividade do Estado perante o parlamento eleito; e liberdade de expressão e associação (institucionalização do

\footnotetext{
${ }^{22}$ Tradução própria.
} 
direito à oposição), assim como proteção dos direitos individuais contra a ação estatal arbitrária (condição necessária para uma democracia estável).

$\mathrm{O}$ argumento dos autores é que, apesar de as democracias existentes divergirem do modelo ideal (que proporciona responsividade igual às preferências dos cidadãos), elas trouxeram avanços significativos. Isso se justifica pelo argumento de que os mesmos fatores que fazem democracia formal avançar são importantes na obtenção de uma democracia real. Assim,

Quanto mais o balanço de classe favorece os interesses da classe subordinada e quanto mais uma sociedade civil densa auxilia em conferir expressão organizacional para esses interesses e simultaneamente constitui uma força contraposta ao poder autônomo e irrestrito do Estado, maiores são as chances não apenas de instalar instituições democráticas e fazê-las estáveis, mas também de aumentar o real peso da tomada de decisões democrática (Rueschemeyer, Stephens e Stephens, 1992: 297) ${ }^{23}$.

Haveria variações no quanto as democracias formais "dão voz a muitos". Em alguns casos, grupos com poder socioeconômico conseguem impedir que decisões contrárias aos seus interesses sejam tomadas. Mas em algumas democracias formais, há ampla participação da sociedade (Rueschemeyer, Stephens e Stephens, 1992).

Ademais, a força das classes subordinadas na política reflete-se em pressões por redistribuição, embora não seja um resultado automático. Dessa forma, a relação entre democracia e distribuição de renda poderia ser pensada em termos de mutualidade: enquanto a distribuição de renda favorece a democracia, o regime democrático também beneficia a distribuição, uma vez que muitos possuem mais voz e assim demandam por uma redistribuição também dos recursos econômicos ${ }^{24}$.

Ainda que a definição formal perca informações importantes sobre uma democracia efetiva, os autores abarcam dimensões essenciais na relação entre igualdade econômica e democracia, como o balanço de poder entre as classes e a abertura do aparato estatal aos interesses delas.

\footnotetext{
${ }^{23}$ Tradução própria.

${ }^{24}$ Essa endogeneidade dificultaria uma abordagem quantitativa do tema. Vale ressaltar ainda que os autores focam mais na democratização entendida como processo em vez da qualidade do regime democrático, depois do estabelecimento das instituições políticas.
} 
O capitalismo é visto como necessário por propiciar desenvolvimento, mas são suas contradições, com o crescimento das classes subordinadas e a decorrente ampliação da participação, que contribuem para o avanço da democracia. O desenvolvimento capitalista ajudou a trazer um aparato institucional que oferece oportunidades para melhorias qualitativas na democracia, embora não haja garantias de que isso ocorrerá. Avanços na qualidade da democracia requerem, porém, transformações no capitalismo, isso é, na estrutura de poder da sociedade.

Os autores destacam, por exemplo, a importância da participação em níveis organizacionais menores. Semelhante às correntes da democracia participativa no que tange a democratização de outras esferas da vida humana, Rueschemeyer, Stephens e Stephens (1992: 299) salientam que "a experiência das pessoas em configurações que não são propriamente políticas possui efeito considerável em suas habilidades, aspirações, confiança e senso de eficácia"25.

Tal desenvolvimento humano está relacionado à concepção de autonomia, uma vez que a independência do juízo de valor associa-se tanto ao aspecto econômico quanto a comportamentos que são gerados com base nos espaços de socialização. Assim, a democratização da esfera do trabalho tem grande relevância. Sobretudo, o controle do poder econômico privado e a redução da desigualdade social fazem parte do caminho para uma democracia substantiva (Rueschemeyer, Stephens e Stephens, 1992).

Entretanto, essa perspectiva se distancia das teorias da democracia participativa por estar mais centrada na estabilidade que na qualidade do regime democrático. Além disso, a operacionalização do conceito proposto pelos autores se assemelha bastante ao modelo liberal-pluralista, que é amplamente criticado pelo participacionismo.

Ainda assim, embora o debate em torno das teorias da modernização esteja centrado na democratização como processo, a qual não se constitui em foco desse trabalho, a discussão é importante pois traz elementos que ligam renda/riqueza à democracia. Primeiramente, cabe destacar que são utilizados conceitos diversos do termo: enquanto para Moore, democracia está relacionada a certo nível de participação e esforço contra regras arbitrárias, Rueschemeyer, Stephens e Stephens adotam um conceito mais formal devido à necessidade de operacionalização.

\footnotetext{
${ }^{25}$ Tradução própria.
} 
Entretanto, o conceito de "democracia efetiva" para os autores ainda está centrado em uma concepção de responsividade igual às demandas dos cidadãos e à questão de "dar voz" à população, o que se aproxima da definição de acesso igualitário ao sistema político. Os mecanismos delineados, que ligariam renda e riqueza à efetivação da democracia, seriam a educação, a socialização e a influência direta exercida no sistema político.

A educação é abordada por Lipset (1959). Maiores níveis de educação, nesse sentido, trariam mais sofisticação política e menos recepção às ideologias extremistas. Assim, educação estaria relacionada mais à estabilidade que a uma questão de participação política, embora essa consequência não possa ser descartada.

Tanto Lipset (1959) quanto Moore (1974 [1966]) abordam a problemática do papel exercido pelas classes sociais. Embora renda não seja o único elemento presente no conceito de classes, ainda é um aspecto importante e ambas as definições - de classe e de renda - estão relacionadas às discussões sobre desigualdade econômica. Isso decorre da acepção de que a desigualdade material é um dos principais fatores ligados à formação da classe e do conflito de classes (Wright, 1994) ${ }^{26}$.

Renda se relaciona tanto à educação e à socialização, pois o acesso a determinados espaços, como escolas, estão restritos a uma questão de renda e classe social, visto que implica em custos. Ademais, a influência política pode ser exercida por meio de contatos com a burocracia recrutada, o que depende também da formação de certa rede de contatos. Tanto as formas de recrutamento quanto o estabelecimento de contatos podem estar ligados à renda e à posição social.

Já a riqueza está diretamente relacionada à influência política direta em termos do controle que exercem os detentores de capital e a dependência estatal em relação a eles, uma vez que o controle de capital tem certo peso nas decisões públicas.

Por fim, questiona-se o conceito de democracia por meio da oposição entre “democracia formal" e "democracia substantiva", em que o princípio da igualdade política retoma seu sentido original de distribuição igualitária de poder político. Ao passo que a democracia formal é utilizada como aproximação devido à viabilidade de operacionalização, a existência dos dois termos denota a insuficiência de considerar meramente as regras institucionais como elemento central da definição de democracia.

\footnotetext{
${ }^{26}$ De fato, sob a ótica do modelo de exploração, o conflito de classe é visto como consequência de uma lógica antagonista do processo relacional de determinação de rendimentos (Wright, 1994).
} 


\subsection{Esboço de quadro teórico: um esforço de sistematização da relação entre renda e}

\section{democracia}

O princípio da igualdade política nunca desapareceu completamente na teoria democrática $^{27}$, mesmo nas vertentes que mais limitaram o alcance do termo e sua amplitude na prática política. Entretanto, o que variou enormemente foi sua interpretação e suas consequências para os modelos de democracia adotados, assim como a relação com os fatores socioeconômicos.

Essa variação de interpretação é consequência direta da diversidade dos conceitos de democracia adotados, que ora se restringem às instituições políticas ora retomam a ênfase na participação popular efetiva.

$\mathrm{Na}$ Antiguidade Clássica, a igualdade política era entendida como princípio fundamental na democracia e se concretizava por meio da igual possibilidade de acesso ao sistema político. Certo nível de igualdade econômica estava relacionado tanto à estabilidade do regime quanto a própria definição de democracia, que se caracterizava como um governo dos pobres.

No entanto, democracia demorou muito para ser reconhecida como uma forma de governo positiva, pautando-se em argumentos que prediziam a incapacidade das massas, até mesmo antes do surgimento do elitismo como corrente teórica. Ademais, a cidadania não possuía a dimensão da atualidade, estando restrita a algumas camadas diminutas da população. Assim, idealizações do modelo grego são infrutíferas, embora permaneça a relevância da concepção grega de democracia em relação ao princípio de igualdade política.

Na corrente liberal-pluralista, a aplicabilidade da igualdade política foi reduzida aos direitos formais, à igualdade perante a lei e à escolha dos representantes por meio das eleições. Embora a definição liberal em si traga a ideia de responsividade igualitária, a

\footnotetext{
${ }^{27}$ Przeworski (2009) discorda dessa perspectiva. Segundo o autor, a palavra "igualdade" foi usada em relação à democracia para designar outra característica - a de generalidade. Se a igualdade reflete algum estado préexistente, não há provas lógicas ou empíricas. Por outro lado, igualdade em outros domínios não implica necessariamente em igualdade política. Além disso, mesmo que os seres humanos tivessem nascido iguais, eles se tornariam desiguais em sociedade e mesmo que as sociedades tivessem uma tendência para a igualdade, as desigualdades seriam suficientes para demandar remédios políticos. A igualdade política instituída pela lei é subjugada pela desigualdade social. De acordo com o autor, igualdade não é uma forma correta de caracterizar a democracia.
} 
operacionalização do conceito passa restritivamente à presença de certos aparatos institucionais, como eleições livres e periódicas e liberdade de associação.

As eleições foram escolhidas como método, embora se distanciassem do princípio fundamental da democracia, pois privilegiavam a legitimidade do regime, como demonstra Manin (1997). O princípio da igualdade política passa a denotar "eleitor, um voto", apesar de a extensão desse direito ainda ter levado algum tempo para abranger outros tipos de eleitor além do tradicional homem burguês.

A relação entre igualdade política e econômica baseia-se em uma questão de acesso a recursos: recursos econômicos são necessários para se adquirir recursos políticos importantes. A renda altera a influência exercida no sistema político e o acesso à informação. Porém, com a exceção de Dahl (1985), que talvez se encaixasse melhor em outra vertente, a relação entre igualdade política e econômica não é aprofundada de modo a questionar as instituições vigentes.

A redução da participação na perspectiva liberal-pluralista foi muito criticada por diversas vertentes da teoria democrática. A teoria deliberativa, por exemplo, baseia-se na existência de uma esfera pública, que atuaria de modo a exercer pressão sobre o Estado. A esfera pública tem como pressuposto a desconsideração de fatores sociais e econômicos, pois predominaria o argumento no debate. Entretanto, essa desconsideração é irreal desde os primórdios da construção da esfera pública. Assim, a abordagem deliberacionista para as condições econômicas é insuficiente.

A relação entre igualdade política e econômica é abordada no trabalho de Rousseau, que influenciou tanto a vertente participativa quanto o republicanismo cívico. No pensamento de Rousseau, as disparidades econômicas comprometiam a estabilidade a formação de juízo autônomo. A instrumentalidade típica da política na corrente liberalpluralista e na deliberativa é criticada no republicanismo cívico, que enxerga a política como fim em si mesmo.

Entre as vertentes da teoria democrática, democracia participativa é a que mais foca na relação entre igualdade política e econômica. A ideia é induzir a participação e, consequentemente, a democracia em instâncias menores para o aprimoramento do regime na instância superior. Nesse sentido, a democratização da indústria ocupa um papel importante nessa vertente. A igualdade econômica é vista como condição da igualdade 
política, pois condições econômicas paritárias são necessárias para que haja uma participação igual.

Embora um dos focos do multiculturalismo concentre-se nos padrões culturais, a questão econômica não passa despercebida. Fraser (2003) mostra que as demandas de redistribuição não podem ser negligenciadas, mesmo em um contexto de ampliação das demandas por reconhecimento. A redistribuição é fundamental, principalmente, para que os grupos minoritários atinjam a paridade de participação.

Por outro lado, pode-se extrair do marxismo observações importantes no que tange ao acesso direto da sociedade aos centros de poder. Se para Offe (1984 [1972]) existe certa porosidade no Estado em relação aos interesses capitalistas, Poulantzas (2000 [1978]) aborda as lutas internas inerentes ao aparato estatal. Cabe aqui indagar, portanto, o papel daqueles que possuem acesso direto ao poder político, isso é os ocupantes de cargos eletivos e a burocracia.

Estando em contato direto com a tomada de decisões, o acesso a esses cargos - seja de forma direta (pela ocupação efetiva deles) ou indireta (por contatos pessoais) - é fundamental no exercício da atividade política. Cabe questionar, assim, se existe algum tipo de padrão nesse acesso (e consequentemente na influência nas decisões políticas), principalmente em termos de um acesso desigual, e se esse padrão estaria relacionado com os rendimentos recebidos pelos indivíduos ou o controle de grandes montantes de capital econômico.

O exercício de influência direta por meio da burocracia e do controle de riqueza é abordado também dentro do debate sobre teorias da modernização. Nesse sentido, Rueschemeyer, Stephens e Stephens (1992) destacam a relação entre aparato estatal e as classes sociais. Outros mecanismos que ligariam renda e riqueza à democracia podem ser extraídos do debate sobre modernização, tais como o papel da educação na sofisticação política, a socialização, além da já citada influência política direta.

Assim, das teorias expostas nessa seção, pode-se inferir diversos "caminhos" pelos quais a distribuição de renda e riqueza afetaria a distribuição de poder político. Alguns fatores que estão relacionados a esses "caminhos" podem ser destacados:

a) Socialização: a renda delimita o acesso a certos espaços, além de ser necessária para o exercício de atividades relacionadas a habilidades que são utilizadas na 
ação política. A democracia participativa aborda o treinamento de trabalhadores na esfera da indústria, o qual seria necessário para o aprendizado democrático. Verba, Schlozman e Brady (1995) demonstram a importância de instituições não políticas - tais como a igreja no caso dos Estados Unidos - para o engajamento cívico, visto que essas instituições auxiliam no desenvolvimento de habilidades necessárias para a atividade política. Alguns locais e instituições implicam em custos em seu acesso, como a escola. Dessa forma, o acesso a esses espaços e consequentemente o desenvolvimento de habilidades e do interesse pela política estão condicionados aos rendimentos que os indivíduos recebem.

b) Educação e informação: Como citado no exemplo anterior, a escola é um espaço condicionado pela renda. Primeiramente devido ao próprio preço de escolas particulares de qualidade. Em segundo lugar, pelos custos associados à educação de forma mais geral, como compra de materiais. De forma semelhante, o acesso a informações também implica em alguns custos, como a compra de revistas, jornais ou a obtenção de outros meios como computador e internet. Embora esses meios estejam mais acessíveis atualmente, ainda há de se destacar a necessidade de pluralidade (ou a falta de) da mídia. A exposição de apenas um ponto de vista ou de determinada ideologia pode ser prejudicial na formação de preferências dos indivíduos, que são construídas com base nos diversos espaços de socialização. Se Downs já mostrara a importância da informação, alguns estudos mais recentes apontam para a relação entre informação e interesse pela política ou para a associação entre a distribuição de informação e a forma com a qual as demandas são atendidas na política (ver Luskin, Fishkin \& Jowell, 2002; Delli Carpini \& Keeter, 1996). Ademais, educação e informação estão interligadas, uma vez que uma compreende capacidades cognitivas fundamentais à compreensão da outra.

c) Acessibilidade: A participação política é determinada por alguns custos mais gerais, como o transporte, o gasto com materiais no caso da militância, entre outros. Esses "outros custos" estão inseridos em "acessibilidade". Além disso, há a acessibilidade em termos sociais, relacionada à inclusão/exclusão social. Dessa forma, o termo refere-se tanto ao acesso físico, como o relacionado a 
custos de transporte ou à logística para exercer atividades políticas, quanto à inclusão/exclusão social. Assim, lida-se não apenas com impedimentos de cunho material para o acesso a determinados lugares, mas a própria noção de adequação, a qual é socialmente construída. Isso corresponde ao fato de o acesso a determinados lugares ser vetado ou restringido a certas pessoas por estar associado a comportamentos e estilos de vida específicos, resultando em ações discriminatórias em relação à classe, raça, sexualidade, ao gênero ou comportamento em geral.

d) Canais de influência política: a influência política direta refere-se ao envolvimento na tomada de decisões. Dois tipos de atores são destacados: os ocupantes de cargos eletivos (como senadores, deputados e presidente da república) e a burocracia de alto escalão que tem acesso direto às decisões políticas. Nesse sentido, a forma com a qual o Estado "seleciona" as demandas a ser atendidas está relacionada com a porosidade do Estado a determinados grupos sociais, seja por contato com detentores de cargo político ou burocrático ou o acesso privilegiado que determinados grupos possuem a esses atores. $\mathrm{O}$ acesso desigual a esses atores pode ocorrer por diversos motivos: o controle de grande montante de capital econômico, que torna o Estado dependente de certos grupos (por exemplo, o caso dos investidores ou do agronegócio), as relações pessoais (redes formadas no trabalho ou nas instituições de ensino), a ação de grupos de interesses que pressionam as instituições políticas ("lobbies") e o financiamento de campanha. Vale ressaltar que a renda atua sobre esses atores: no caso dos grupos de interesse, muitos deles são financiados por grupos de indivíduos que detém controle sobre capital econômico ou possuem elevados rendimentos; a formação de redes depende do acesso a determinados espaços, cuja entrada depende da renda (uma universidade de prestígio, por exemplo). $\mathrm{O}$ financiamento de campanha e a dependência estrutural do Estado envolvem diretamente grandes montantes de capital, o que salienta a interação entre poder político e poder econômico.

Tais caminhos e a relação com as correntes de pensamento político encontram-se resumidos na tabela 1 : 
Tabela 1 - Correntes do pensamento político

\begin{tabular}{|c|c|c|c|c|c|}
\hline Correntes & Socialização & Educação & Informação & Influência política direta & Outros custos \\
\hline $\begin{array}{l}\text { Liberalismo/ } \\
\text { Pluralismo }\end{array}$ & $\begin{array}{l}\text { Socialização política } \\
\text { voltada para } \\
\text { mitigação de conflitos. } \\
\text { Ação de múltiplos } \\
\text { grupos gera equilíbrio } \\
\text { de poder. }\end{array}$ & $\begin{array}{l}\text { Educação é vista como } \\
\text { meio para adquirir } \\
\text { capacidades relativas } \\
\text { ao processamento de } \\
\text { informação. Está } \\
\text { relacionada com a } \\
\text { informação. }\end{array}$ & $\begin{array}{l}\text { Informação é } \\
\text { entendida como } \\
\text { recurso } \\
\text { necessário à } \\
\text { atividade política } \\
\text { que implica em } \\
\text { custos com os } \\
\text { quais os } \\
\text { indivíduos devem } \\
\text { arcar. }\end{array}$ & $\begin{array}{l}\text { Contestação, inclusão e } \\
\text { consequente desagregação } \\
\text { do poder seriam suficientes } \\
\text { para que as preferências dos } \\
\text { indivíduos fossem } \\
\text { razoavelmente respeitadas. } \\
\text { Embora mencione influência } \\
\text { maior de alguns grupos ou } \\
\text { indivíduos, não discute a } \\
\text { questão de forma } \\
\text { aprofundada. }\end{array}$ & $\begin{array}{l}\text { Custos de votar, } \\
\text { custos } \\
\text { econômicos para } \\
\text { agir politicamente } \\
\text { (importância do } \\
\text { cálculo custo- } \\
\text { benefício). }\end{array}$ \\
\hline Deliberativa & $\begin{array}{l}\text { Ocorre por meio do } \\
\text { debate (trocas } \\
\text { discursivas } \\
\text { desinteressadas). }\end{array}$ & $\begin{array}{l}\text { Socializada nas trocas } \\
\text { discursivas. }\end{array}$ & $\begin{array}{l}\text { Debate é aspecto } \\
\text { central. Porém, } \\
\text { pressupõe } \\
\text { situação de "fala } \\
\text { ideal". }\end{array}$ & $\begin{array}{l}\text { Sociedade civil pressiona o } \\
\text { Estado. }\end{array}$ & - \\
\hline Republicanismo & Engajamento cívico. & - & - & $\begin{array}{l}\text { Envolvimento dos cidadãos } \\
\text { com decisões públicas. }\end{array}$ & \\
\hline Participativa & $\begin{array}{l}\text { Democratização de } \\
\text { outras esferas e } \\
\text { treinamento para o } \\
\text { exercício da } \\
\text { democracia. }\end{array}$ & $\begin{array}{l}\text { Desigualdades de } \\
\text { riqueza e renda } \\
\text { implicam em } \\
\text { desigualdade na } \\
\text { educação. } \\
\text { Democratização de } \\
\text { espaços como a escola } \\
\text { é necessária para que } \\
\text { indivíduos aprendam a } \\
\text { cidadania. Função } \\
\text { educativa da } \\
\text { participação. }\end{array}$ & - & $\begin{array}{l}\text { Participação ativa dos } \\
\text { cidadãos. }\end{array}$ & $\begin{array}{l}\text { Dependência } \\
\text { econômica } \\
\text { impede } \\
\text { independência de } \\
\text { juízo de valor, } \\
\text { necessária para a } \\
\text { participação } \\
\text { efetiva. }\end{array}$ \\
\hline $\begin{array}{l}\text { Multiculturalismo } \\
\text { e Teorias da } \\
\text { Diferença }\end{array}$ & $\begin{array}{l}\text { Pertencimento a } \\
\text { certas coletividades e } \\
\text { sua relação com } \\
\text { padrões } \\
\text { institucionalizados de } \\
\text { valor cultural. } \\
\text { Paridade está } \\
\text { relacionada com } \\
\text { oportunidades de } \\
\text { interação entre } \\
\text { pessoas. }\end{array}$ & - & - & $\begin{array}{l}\text { Crítica ao "ideal de } \\
\text { imparcialidade" do Estado, } \\
\text { hierárquica de grupos e } \\
\text { opressão a minorias. }\end{array}$ & \\
\hline Marxismo & $\begin{array}{l}\text { Classes sociais e } \\
\text { acesso a } \\
\text { determinados } \\
\text { espaços. }\end{array}$ & $\begin{array}{l}\text { Oportunidades sociais } \\
\text { reais }\end{array}$ & - & $\begin{array}{l}\text { Permeabilidade e } \\
\text { seletividade do Estado aos } \\
\text { interesses de grupos } \\
\text { determinados. }\end{array}$ & \\
\hline $\begin{array}{l}\text { Debate sobre } \\
\text { modernização }\end{array}$ & $\begin{array}{l}\text { Democratização de } \\
\text { esferas em níveis } \\
\text { organizacionais } \\
\text { menores }\end{array}$ & $\begin{array}{l}\text { Aumenta sofisticação } \\
\text { política dos indivíduos } \\
\text { e diminui } \\
\text { receptividade às } \\
\text { ideologias mais } \\
\text { extremas }\end{array}$ & - & $\begin{array}{l}\text { Relação diferenciada do } \\
\text { Estado com certas classes } \\
\text { sociais e acesso à burocracia } \\
\text { (Rueschemeyer, Stephens e } \\
\text { Stephens, 1992). }\end{array}$ & \\
\hline
\end{tabular}

Fonte: elaboração da autora, mediante revisão bibliográfica.

Essas condições - socialização, educação, informação, influência política direta relacionam-se à democracia pelos impactos que exercem na participação política, como esquematizado na figura 2 : 
Figura 2 - Sistematização da relação entre os conceitos.

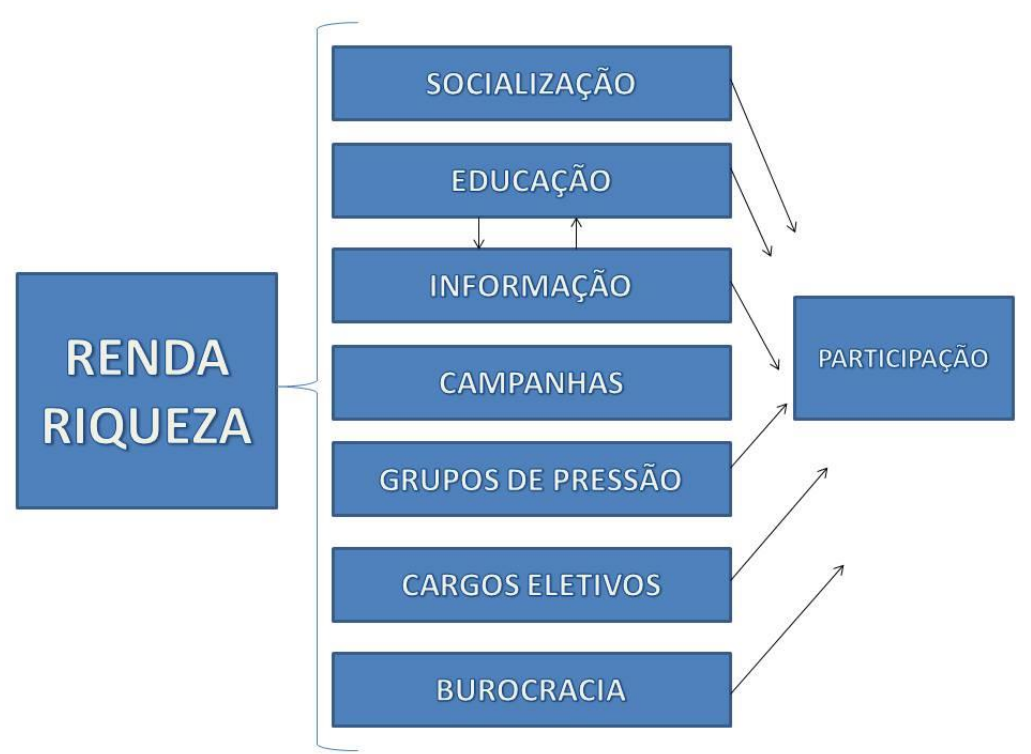

Nota-se, ainda, que várias das correntes analisadas abordam a questão da independência e da autonomia do indivíduo perante outros, o que depende de certo nível de igualdade econômica. Além dos fatores já citados, o nível de igualdade econômica poderia contribuir até mesmo para a satisfação e crença no regime democrático, uma vez que fatores econômicos são importantes na avaliação dos regimes políticos. 


\section{III \\ MECANISMOS ENTRE DISTRIBUIÇÃO E DEMOCRACIA}

Os capítulos anteriores mostraram que grande parte da literatura sobre democracia aborda, mesmo que superficialmente, a questão da interação entre igualdade econômica e igualdade política. Acredita-se que essa relação seja central devido ao próprio conceito de democracia estar atrelado a uma concepção de igualdade política, mesmo que essa noção tenha variado segundo as diferentes correntes de pensamento político.

Embora existam alguns modelos que relacionem distribuição de renda e riqueza ao regime democrático, poucos especificam o que estaria "no meio" dessa relação, isso é, quais os mecanismos que fariam com que uma distribuição mais igualitária de renda/riqueza se relacionasse positivamente com a presença ou o desenvolvimento da democracia. Provavelmente algumas causas das lacunas nessa área residem na dificuldade de delimitar e operacionalizar o conceito de democracia, tendo em vista que os índices existentes conseguem apreender apenas alguns aspectos formais do regime democrático.

A democracia como forma social, contudo, é tão importante quanto as regras de funcionamento do regime, uma vez que distribuição de poder político implica necessariamente em relações diversas que os grupos e indivíduos possuem com o sistema político. Considerando a democracia como distribuição igualitária de poder, torna-se imperativo analisar, portanto, quais fatores determinam a diferença no acesso ao poder por parte dos grupos e indivíduos que compõem a sociedade. Em outras palavras, cabe indagar quais são os fatores que contribuem para a igualdade política e como eles se relacionam com a distribuição de renda e riqueza.

Destarte, esse capítulo propõe um esforço de teorização no que tange à especificação desses fatores e a relação deles com as variáveis "renda" e a "riqueza". Assim, pretende-se sistematizar os mecanismos pelos quais renda e riqueza afetam as oportunidades de participação política e, em consequência, a efetividade da democracia.

Em um primeiro momento, são destacados fatores que incidem sobre atributos considerados como "individuais" e que estão associados a menor ou maior capacidade de 
participação política. Acessibilidade, socialização, educação e acesso à informação são fatores que contribuem para o desenvolvimento de determinadas capacidades relacionadas ao exercício da atividade política, seja como militante ou como político profissional. Por outro lado, essas capacidades, aliadas às oportunidades de participação, incidem sobre a percepção que os indivíduos possuem sobre a efetividade da ação política.

Em um segundo momento, pretende-se abordar os canais que ligam propriamente os indivíduos ao sistema político. Destaca-se, dessa forma, como a interação entre aspectos individuais e canais contribuem para a existência e aproveitamento de certas oportunidades de participação política por diferentes grupos presentes na sociedade. $\mathrm{O}$ argumento central é que a distribuição de renda e riqueza causa uma larga discrepância na distribuição dessas oportunidades e capacidades, o que contribui consequentemente para que alguns grupos ou indivíduos detenham mais poder que outros.

\subsection{Determinantes sociais}

\subsubsection{Socialização e acessibilidade}

A democracia participativa e o debate sobre modernização lidam, de forma distinta, com o conceito de democracia e sua relação com o acesso a recursos econômicos. Enquanto a questão central para a democracia participativa refere-se à ampliação da participação como aperfeiçoamento da democracia, o debate sobre modernização foca no papel das classes sociais no processo de democratização.

Em ambos os casos, contudo, demonstra-se certa preocupação com o desenvolvimento de habilidades necessárias à atividade política. Nesse sentido, as duas abordagens concentram-se em como indivíduos podem desenvolver capacidades e habilidades úteis ao exercício de atividades políticas em espaços que não são considerados diretamente políticos, como a escola e o local de trabalho. Assim, o acesso a esses espaços condicionaria a aquisição dessas capacidades, uma vez que tais espaços estimulam e impactam comportamentos individuais relacionados à política.

Tais comportamentos estão também relacionados a qualidades psicológicas, como a questão da autoconfiança e da crença na efetividade da participação. Quando a democracia é estendida para instituições centrais nas quais os indivíduos passam a maior parte de suas vidas, é mais provável que eles acreditem que a participação vale o esforço. Consequentemente, eles participarão mais ativamente de decisões coletivas, inclusive em 
âmbito institucional maior. Se, por outro lado, eles estão em uma posição sistematicamente marginalizada, é possível que eles sintam que suas visões não são consideradas e, portanto, participem menos (Held, 2006).

Ademais, a atividade política exige certas capacidades, como a tolerância com opiniões contrárias, a oratória e a habilidade de negociação. Essas capacidades podem ser adquiridas também em instituições não diretamente políticas ${ }^{28}$ e esferas diversas de socialização, como a escola, a família e o local de trabalho.

O processo participativo abrange fatores como motivação e capacidade, que podem ser adquiridas em instituições não políticas fundamentais com as quais os indivíduos estão associados durante o curso da vida deles. A motivação está atrelada a uma questão de escolha, uma vez que grande parte das atividades políticas - envolvimento em campanhas, organização de petições, etc. - são voluntárias.

Entretanto, trata-se de escolhas constrangidas, visto que as várias formas de participação impõem certos requisitos, como a disposição de tempo ou dinheiro e capacidades, como, por exemplo, habilidade para escrever uma carta (Verba, Schlozman e Brady, 1995).

Sobretudo, o treinamento na tomada de decisões coletivas nesses ambientes está relacionado ao desenvolvimento de independência na tomada de decisões. Se certo indivíduo é acostumado a uma posição submissa no cotidiano, é mais provável que ele adote essa mesma postura a nível institucional mais abrangente. Por outro lado, se há mais oportunidades de participação a nível local, os cidadãos e as cidadãs possuem mais chances de aprender sobre assuntos fundamentais em termos de recursos e controle e estarão mais aptos a julgar questões nacionais, analisar a atuação dos representantes políticos e participar de decisões de escopo nacional (Held, 2006).

Assim, a democratização de esferas em níveis organizacionais menores também é destacada por Rueschemeyer, Stephens e Stephens (1992) como uma necessidade para se atingir uma democracia substantiva. A participação de cidadãos e cidadãs em instituições

\footnotetext{
${ }^{28}$ No decorrer desse capítulo, usarei o termo "instituições não políticas" para me referir a essas instituições. Entretanto, cabe destacar que a diferença entre essas entidades e as consideradas como propriamente políticas não possui fronteiras nítidas. Pelo contrário, o argumento implícito nesse capítulo é que essas esferas de atuação são também políticas, vide a dificuldade de separação entre o que é público e o que é privado crítica pertinente nos estudos feministas.
} 
que não são diretamente políticas é importante para o desenvolvimento de habilidades e comportamentos associados à participação política independente.

Nos Estados Unidos, por exemplo, há um papel significativo da religião no processo participativo. A igreja desempenhou um papel ativo em movimentos políticos, como a luta pelos direitos civis. Sobretudo, a igreja é um espaço que propicia oportunidades para o desenvolvimento de capacidades associadas à política, como a arrecadação de fundos (Verba, Schlozman e Brady, 1995). Assim, instituições religiosas podem servir como espaços de socialização política, mesmo não sendo consideradas comumente como instituições políticas per $s i^{29}$.

Dessa maneira, nota-se que instituições e associações às quais os indivíduos se vinculam no curso de suas vidas podem contribuir para incentivar comportamentos participativos, mesmo que elas não estejam ligadas diretamente a alguma atividade política. As oportunidades de engajamento dentro dessas instituições atuariam, portanto, como uma espécie de treinamento, que habilitaria os indivíduos a participarem em escalas maiores diretamente relacionadas ao que se entende por política.

De forma geral, observa-se uma tendência, no contexto brasileiro, de maior engajamento por parte de pessoas com algum vínculo a organizações associativas, em que a modalidade de participação depende do tipo de associativismo, como demonstra a tabela 2 (Azevedo, Santos Júnior e Ribeiro, 2009).

Todavia, vale destacar que, na supracitada tabela, uma pessoa pode participar de mais um tipo de mobilização, o que significa que a soma de percentuais não será correspondente a $100 \%$. Sobretudo é preciso esclarecer que a tabela não traz dados sobre o percentual que não participa de nenhuma modalidade, o que impede uma análise mais conclusiva acerca do potencial do associativismo de forma geral. Ainda assim, é possível extrair algumas ilações acerca da relação entre associativismo e tipos de mobilização.

\footnotetext{
${ }^{29}$ Destaca-se, aqui, o papel das igrejas no engajamento. Isso não significa, porém, que o ativismo seja empreendido de forma positiva. Em relação à ideologia, por exemplo, a igreja tem desempenhado um papel dúbio. Se por um lado, associações religiosas foram progressistas no sentido da democratização e em algumas temáticas - caso das Pastorais e a questão da luta pela terra, por exemplo - por outro, ela se constitui em uma força conservadora quando se trata de assuntos como o casamento homossexual e a ampliação do aborto legal (ver Ganança, 2006). No caso brasileiro, cabe destacar, ainda, a influência política diretamente exercida pelas religiões na atuação de políticos ligados a elas, como ocorre com a Frente Parlamentar Evangélica. Não por acaso, a questão do aborto foi uma das polêmicas temáticas que nortearam os debates das eleições de 2010, tendo em vista o papel dos eleitores católicos e evangélicos e a força política de grupos religiosos.
} 
Tabela 2 - Associativismo e mobilização sociopolítica no Brasil (2006), em \%

\begin{tabular}{l|c|c|c|c|c|c|c}
\hline \multicolumn{1}{|c|}{ Associativismo } & $\begin{array}{c}\text { Assinar } \\
\text { petição ou } \\
\text { fazer abaixo- } \\
\text { assinado }\end{array}$ & $\begin{array}{c}\text { Boicotar } \\
\text { produtos }\end{array}$ & $\begin{array}{c}\text { Participar em } \\
\text { manifestação }\end{array}$ & $\begin{array}{c}\text { Participar em } \\
\text { comício ou } \\
\text { em reunião } \\
\text { política }\end{array}$ & $\begin{array}{c}\text { Dar } \\
\text { dinheiro } \\
\text { para causa } \\
\text { pública }\end{array}$ & $\begin{array}{c}\text { Fórum ou } \\
\text { grupo de } \\
\text { discussão } \\
\text { pela } \\
\text { internet }\end{array}$ & $\begin{array}{c}\text { Participar } \\
\text { de greve }\end{array}$ \\
\hline Partido político & 52,7 & 23,3 & 34,9 & 68,2 & 20,2 & 17,0 & 19,4 \\
\hline $\begin{array}{l}\text { Sindicato, grêmio } \\
\text { ou associação } \\
\text { profissional }\end{array}$ & 50,2 & 20,3 & 34,5 & 54,0 & 14,9 & 14,1 & 24,5 \\
\hline $\begin{array}{l}\text { Igreja ou outra } \\
\text { organização } \\
\text { religiosa }\end{array}$ & 36,1 & 9,6 & 19,7 & 40,6 & 12,5 & 6,1 & 10,7 \\
\hline $\begin{array}{l}\text { Grupo desportivo, } \\
\text { cultural ou } \\
\text { recreativo }\end{array}$ & 53,9 & 24,9 & 37,3 & 51,9 & 17,0 & 18,3 & 19,9 \\
\hline $\begin{array}{l}\text { Outra associação } \\
\text { voluntária }\end{array}$ & 54,5 & 54,5 & 36,6 & 47,6 & 22,8 & 19,3 & 23,5 \\
\hline
\end{tabular}

Fonte: Pesquisa Observatório das Metrópoles, IUPERJ, ICS-UL, ISRO (2006) apud Azevedo, Santos Júnior e Ribeiro (2009).

Nota-se, pela tabela 2, que mesmo associações que não estão diretamente ligadas à política, como organizações religiosas ou grupos desportivos, possuem certo impacto sobre algumas modalidades de participação política, tais como participação em comícios e manifestações ${ }^{30}$, mesmo que o associativismo religioso seja o que menos engaje em mobilizações sociopolíticas, como salientam os autores.

O papel de instituições não explicitamente políticas e esferas de socialização fundamentais no engajamento individual foi abordado vastamente na teoria política, abrangendo vertentes diversas como a democracia participativa, o debate sobre modernização e até mesmo a abordagem do Voluntarismo Cívico tal como expressa por Verba, Schlozman e Brady (1995).

De forma geral, elas dão ênfase na participação e consideram o desenvolvimento de capacidades individuais e o treinamento como fatores importantes no engajamento político. Como afirmam Verba, Schlozman e Brady (1995: 17):

[...] instituições sociais desempenham um papel importante em estimular cidadãos a fazer parte da política por cultivar um engajamento psicológico na política e por servir de lócus de recrutamento para atividade. Qualquer uma dessas configurações pode servir como o local para exposição a

\footnotetext{
${ }^{30}$ Não se exclui, porém, outros fatores que se constituem como causas ou como incentivo à participação: como salientam os autores (Azevedo, Santos Júnior e Ribeiro, 2009), a participação em comícios pode ser motivada por outros aspectos, como a realização de shows nesse tipo de evento. De forma semelhante, petições e manifestações podem indicar outros fatores além da dimensão política.
} 
estímulos políticos - por exemplo, um argumento sobre política na mesa de jantar, uma sermão sobre um assunto público na igreja, uma discussão política com um colega de trabalho ou membro de organização ${ }^{31}$.

As vertentes convergem no sentido de salientar a importância de certas instituições e esferas de socialização para fomentar o engajamento político, porém possuem perspectivas distintas.

A abordagem de Verba, Schlozman e Brady (1995) distingue-se da democracia participativa por focar na participação como forma de comunicação e pressão para que os cidadãos tenham suas preferências atendidas pelos tomadores de decisões. Nesse sentido, a desigualdade de participação seria um empecilho à democracia apenas se a fonte dessas desigualdades não estivesse relacionada à vontade autônoma dos indivíduos ${ }^{32}$.

A perspectiva da cultura cívica aproxima-se da abordagem de Putnam (1996), em que o ponto central é a relação entre sentimento e envolvimento cívico, seja visualizado como capital social ou como cultura. Por outro lado, a democracia participativa discute as oportunidades reais de participação das quais dispõem os cidadãos e cidadãs, em uma crítica ao reducionismo da democracia liberal. Enquanto na abordagem cívica é atribuída mais importância na questão da confiança interpessoal, a democracia participativa enfatiza a necessidade de efetivo poder de decisão, destacando-se a capacidade decisória local.

O problema da abordagem da cultura cívica é que ela associa o comportamento dos cidadãos no que tange à participação quase exclusivamente à "crença" ou ao "sentimento" cívico, em vez de abordar as reais possibilidades que os indivíduos dispõem de intervenção no sistema político.

Isso não significa que a confiança interpessoal ou o sentimento cívico sejam irrelevantes. Laços sociais são importantes para fomentar cooperação e relações sociais igualitárias, elementos importantes no engajamento em ações coletivas. O aproveitamento de espaços comuns coletivos em que indivíduos possam interagir é um dos fatores que influenciam na formação de confiança interpessoal e laços sociais. Porém, a existência de oportunidades reais não pode ser negligenciada, tanto no espaço institucional quanto na capacidade dos indivíduos de utilizarem essas oportunidades, sob a qual infere uma série de determinantes sociais.

\footnotetext{
${ }^{31}$ Tradução própria.

${ }^{32}$ Vale destacar, porém, que a própria "vontade autônoma" é construída em um processo no qual as esferas de socialização possuem papel fundamental.
} 
Cabe destacar ainda que "crença", "sentimento" e "confiança" não são dados determinados, mas elementos construídos, com base também nas oportunidades de participação existentes. Em termos gerais, a inexistência de possibilidades de intervenção nas decisões públicas no sistema político afeta diretamente a percepção que as pessoas possuem sobre a eficácia da mobilização política.

O debate sobre desenvolvimento, por outro lado, foca na questão da aquisição de recursos necessários para o exercício da atividade política, em termos de capacidades e habilidades adquiridas nessas instituições. Tais discussões estão mais focadas no papel das classes sociais, principalmente em sua relação com a estabilidade democrática. Renda e riqueza entram na discussão como variáveis relacionadas ao desenvolvimento econômico, aspecto central dessas teorias.

As perspectivas aqui apresentadas não são necessariamente opostas, uma vez que há interação entre "cultura", "capacidade" e "estrutura de oportunidades". A abordagem proposta nesse trabalho está focada na estrutura de oportunidades das quais dispõem os indivíduos. Essa estrutura determinaria o "sentimento" de distanciamento ou proximidade que os cidadãos e as cidadãs possuem em relação ao sistema político.

Nesse sentido, fatores como educação e acesso à informação teriam impacto no aproveitamento dessas oportunidades. A questão central aqui é, porém, como a distribuição de renda e riqueza afeta a disparidade no acesso a essas oportunidades de participação pelos diferentes grupos e indivíduos que compõem a sociedade.

No que tange à socialização, cabe indagar como especificamente os fatores "renda" e "riqueza" entrariam nessa equação que associa "engajamento", "participação", "capacidades" ao envolvimento em certos espaços, que podem não ser propriamente políticos ${ }^{33}$.

A interação entre componentes do status socioeconômico - nível de educação, renda e ocupação - e atividade política dos cidadãos possui fortes bases empíricas (Verba,

\footnotetext{
${ }^{33}$ O argumento de Verba, Schlozman e Brady (1995), nesse sentido, é que os impactos da interação entre os fatores socioeconômicos dependem da forma de participação que se está considerando (arrecadação de fundos para campanhas e voto são formas de participação distintas, por exemplo). Esse trabalho considera a participação mais como uma condição geral em vez de abordar suas divisões em "tipos", embora não descarte a relevância dessa divisão. Sobretudo, os autores apontam para uma divisão entre atividades que exigem "tempo" e atividades que exigem "dinheiro". Nosso argumento é que mesmo as atividades que se inserem na categoria "tempo" não escapariam da influência da renda, pois pode existir certa dependência entre receita e disponibilidade de "tempo livre", até mesmo quando esse recurso econômico não é fruto de um ofício, mas de outras fontes (como heranças, investimentos, aluguéis, etc.).
} 
Schlozman e Brady, 1995). Todavia, propõe-se uma sistematização maior em relação aos impactos da distribuição de renda sobre cada um dos componentes que a ligam a uma participação política mais efetiva por parte dos cidadãos e cidadãs.

O problema abordado aqui é: levando em consideração que as esferas de socialização da vida diária dos indivíduos estão relacionadas aos níveis de participação e ativismo político, como a renda afeta a socialização? Possíveis respostas a essa questão encontram-se nas formas de interação entre renda e acesso a determinados espaços e impactos dos fatores socioeconômicos nas relações desenvolvidas dentro desses espaços.

Primeiramente, uma vez que a renda está relacionada às condições de moradia, é plausível supor que ela condicione, em certo nível, a proximidade dos indivíduos a locais como associações desportivas, instituições religiosas e escolas de boa qualidade. A construção e o desenvolvimento de locais públicos em que as pessoas interajam entre si é fundamental para a circulação da informação e o exercício da atividade discursiva, necessária a qualquer ação política.

Esses espaços comuns também contribuem para a formação de vínculos afetivos entre as pessoas - o que pode contribuir para uma cultura de cooperação. $\mathrm{O}$ fomento de relações sociais igualitárias depende em certa medida da existência de alguns vínculos entre os indivíduos, os quais são mais facilmente desenvolvidos quando há uma convivência comum.

Como salienta Sérgio Costa (1997: 190):

O núcleo destes espaços sociais, caracterizado pela presença do telefone público,
da padaria etc., demarca topograficamente o lócus de relações de reconhecimento
mútuo e interação comunicativa entre os moradores. Tem lugar, nesse contexto,
o intercâmbio regular e sistemático de informações e impressões, favorecendo
um processo de formação de opinião pública paralelo àquele dirigido pelos
meios de comunicação de massa.

Seria o caso de questionar qual o potencial desses espaços como incentivo à participação política e se o aproveitamento desses espaços depende do nível de renda. Sobretudo, renda incide sobre o acesso até mesmo de locais destinados especificamente a fomentar a participação política.

No Brasil, há um esforço no sentido de fomentar mecanismos participativos relacionados à gestão pública e que incentivem a proximidade dos cidadãos e cidadãs à 
atividade política, desde a Constituição de 1988, não por acaso chamada de "Constituição Cidadã". Exemplos desse tipo de iniciativa são o Orçamento Participativo (OP) e os Conselhos de Gestão, embora o desenho do OP se aproxime mais de uma arena deliberativa.

Entretanto, é razoável supor que o diferencial de renda e riqueza pode ser uma barreira no acesso a esses mecanismos, visto que o status socioeconômico dos indivíduos afeta a percepção e conhecimento deles sobre esse tipo de iniciativa, além de gerar assimetrias no debate. Como demonstrado pela Tabela 3, indivíduos com menores níveis de renda e de ensino conhecem menos esse tipo de iniciativa, ainda que o conhecimento não implique necessariamente em participação (Fedozzi, 2009).

Tabela 3 - Participação no Orçamento Participativo ${ }^{34}$ (Porto Alegre)

\begin{tabular}{|c|c|c|c|c|c|c|c|c|c|c|c|c|}
\hline \multirow[b]{2}{*}{ RESP } & \multirow[b]{2}{*}{ TOTAL } & \multicolumn{2}{|c|}{ SEXO } & \multicolumn{5}{|c|}{ RENDA FAMILIAR (EM SALÁRIOS MÍNIMOS) } & \multicolumn{4}{|c|}{ GRAU DE INSTRUÇÃO } \\
\hline & & $\mathrm{M}$ & $\mathrm{F}$ & $\begin{array}{l}\text { ATÉ } \\
1\end{array}$ & $\begin{array}{l}\text { MAIS } \\
\text { DE } 1 \\
\text { A } 2\end{array}$ & $\begin{array}{l}\text { MAIS } \\
\text { DE } 2 \\
\text { A } 5\end{array}$ & $\begin{array}{l}\text { MAIS } \\
\text { DE } 5 \\
\text { A } 10\end{array}$ & $\begin{array}{l}\text { MAIS } \\
\text { DE } 10\end{array}$ & ATÉ 4ạ & $\begin{array}{l}5^{a} \mathrm{~A} \\
8^{a}\end{array}$ & MÉDIO & SUPERIOR \\
\hline $\begin{array}{l}\text { Conhece e } \\
\text { já } \\
\text { participou }\end{array}$ & $6 \%$ & $7 \%$ & $5 \%$ & $3 \%$ & $5 \%$ & $7 \%$ & $10 \%$ & $12 \%$ & $5 \%$ & $5 \%$ & $7 \%$ & $11 \%$ \\
\hline $\begin{array}{l}\text { Conhece e } \\
\text { nunca } \\
\text { participou }\end{array}$ & $25 \%$ & $24 \%$ & $26 \%$ & $16 \%$ & $18 \%$ & $29 \%$ & $37 \%$ & $44 \%$ & $17 \%$ & $23 \%$ & $30 \%$ & $50 \%$ \\
\hline $\begin{array}{l}\text { Não } \\
\text { conhece }\end{array}$ & $69 \%$ & $69 \%$ & $69 \%$ & $81 \%$ & $77 \%$ & $64 \%$ & $53 \%$ & $44 \%$ & $79 \%$ & $72 \%$ & $62 \%$ & $39 \%$ \\
\hline
\end{tabular}

Fonte: ONG Ação Educativa e IBOPE apud Fedozzi (2009).

Em segundo lugar, fatores socioeconômicos contribuem para hierarquias formadas dentro dos espaços de socialização, sejam eles diretamente políticos ou não. Mesmo dentro de iniciativas consideradas como participativas, nota-se diferenças na participação entre os segmentos sociais. A pesquisa realizada sobre o perfil dos participantes do OP em Porto Alegre demonstra que embora a iniciativa constitua-se em um aparato de maior inclusão de grupos sociais marginalizados, desigualdades relativas a gênero, raça e posição social são reproduzidas na ocupação de cargos hierárquicos.

Como afirma Fedozzi (2009: 216):

Se, em termos gerais, o OP mostra-se uma estrutura aberta de oportunidades aos setores historicamente excluídos do desenvolvimento sociourbano, por outro lado, as variáveis "nível de ensino" e "renda familiar" exercem fortes assimetrias

\footnotetext{
${ }^{34}$ Perfil das respostas à pergunta "O Sr(a) já participou ou nunca participou destas práticas capazes de influenciar as políticas públicas?”.
} 
entre os participantes no que diz respeito à ocupação de postos de representação na hierarquia do mesmo ${ }^{35}$.

De forma semelhante, hierarquias dentro de esferas de socialização podem contribuir para formação de atitudes servientes. Essas esferas se constituem em espaços importantes de aquisição de novas experiências de vida, que influenciam o relacionamento das pessoas com a política. Assim,

Também é importante avaliar em que medida as pessoas conversam sobre política em seu cotidiano, considerando o local de trabalho; encontros informais com os amigos; a própria casa ou a de seus familiares; reuniões associativas; ou ainda as conversas com os vizinhos (Azevedo, Santos Júnior e Ribeiro, 2009: 717).

Embora "conversar" não implique necessariamente em poder de intervenção, a troca de informações é importante para despertar o interesse na política, contribuindo também para a construção de opiniões. A pesquisa realizada em algumas metrópoles brasileiras - São Paulo, Porto Alegre, Rio de Janeiro, Belo Horizonte, Recife, Natal e Goiânia - mostra que, no geral, há uma média muito baixa no que tange à exposição à política tanto na socialização primária quanto na secundária. Esses dados estão ilustrados na Tabela 4.

Nesse sentido, socialização primária corresponde às esferas familiar e escolar, durante o período da infância, adolescência e juventude. Já a socialização secundária refere-se "aos novos processos de diferenciação decorrentes da exposição a novos grupos de referência e a novas experiências de vida" (Azevedo, Santos Júnior e Ribeiro, 2009: 717), abrangendo, dessa forma, o trabalho, a casa e os círculos sociais compostos por amigos.

Verifica-se, assim, que, os brasileiros em geral, falam muito pouco sobre política nesses espaços.

Tabela 4 - Socialização em cidades selecionadas, 2006-2008

\begin{tabular}{l|c|c|c|c}
\hline \multirow{2}{*}{ Cidade } & \multicolumn{2}{|c|}{ Socialização Primária } & \multicolumn{2}{c}{ Socialização secundária } \\
\cline { 2 - 5 } & Média & $\mathbf{N}$ & Média & $\mathbf{N}$ \\
\hline São Paulo & $2,38 \mathrm{~d}$ & 380 & $2,26 \mathrm{~d}$ & 382 \\
\hline Porto Alegre & $2,42 \mathrm{~d}$ & 378 & $2,24 \mathrm{~d}$ & 380 \\
\hline
\end{tabular}

\footnotetext{
${ }^{35}$ Não se descarta, contudo, certo efeito redistributivo dos OPs, em que regiões que ocupam menores postos em termos de renda tende a ocupar maiores postos no número de obras e investimentos (Fedozzi, 2009).
} 


\begin{tabular}{l|c|c|c|c}
\hline Rio de Janeiro & $2,11 \mathrm{c}$ & 486 & $2,09 \mathrm{c}$ & 496 \\
\hline Belo Horizonte & $1,92 \mathrm{a}$ & 364 & $1,53 \mathrm{a}$ & 383 \\
\hline Recife & $1,92 \mathrm{a}$ & 366 & $2,01 \mathrm{c}$ & 372 \\
\hline Natal & $1,98 \mathrm{a}, \mathrm{b}$ & 362 & $1,89 \mathrm{~b}$ & 378 \\
\hline Goiânia & $2,07 \mathrm{~b}, \mathrm{c}$ & 379 & $2,01 \mathrm{c}$ & 379 \\
\hline Brasil & $\mathbf{2 , 0 6}$ & $\mathbf{1 . 9 7 9}$ & $\mathbf{2 , 0 6}$ & $\mathbf{1 . 9 7 9}$ \\
\hline
\end{tabular}

Fonte: Pesquisa Observatório das Metrópoles, IUPERJ, ICS-UL, ISRP (2006-2008) apud Azevedo, Santos Júnior e Ribeiro, 2009.

Escala: (1) "nunca" a (4) "frequentemente".

Anova: F (6,2704) = 20,287; $\mathrm{p}<0,001$.

Letras diferentes representam grupos estatisticamente diferentes entre si; letras iguais, grupos não estatisticamente diferentes entre si (Duncan a $\mathrm{p}<0,05)^{36}$.

A principal observação feita sobre essa tendência, contudo, é o questionamento quanto aos motivos que poderiam causa-la. É possível pensar em diversas hipóteses que tentam responder a essa indagação. Possivelmente, há falta de incentivos por parte das instituições por meio de suas regras, que podem não ser totalmente abertas à participação de todos os seus membros. Por exemplo: em um local como a escola, geralmente os estudantes possuem pouca margem de liberdade para deliberar sobre assuntos internos, que ficam a cargo dos professores, diretores e funcionários, quando não estão restritos apenas ao conselho diretivo ou a cargos superiores.

Assim, ao passo que a baixa exposição à política pode afetar o engajamento, simultaneamente ela pode indicar que está presente um contexto de fortes hierarquias, o que poderia comprometer a participação política por parte de alguns grupos específicos.

Sobretudo, relações hierárquicas em espaços como escolas e locais de trabalho contribuem para o desenvolvimento de assimetrias de poder decisório, que podem restringir as oportunidades de participação dos indivíduos e simultaneamente prejudicar o interesse pela política e a aquisição de habilidades necessárias ao exercício da atividade pública.

No ambiente de trabalho, essa influência é ainda mais perceptível, pois a existência de cargos e o controle dos recursos da empresa por parte dos proprietários gera uma desigualdade nítida entre duas categorias representadas pelos termos "trabalhador" e “patrão". Nesse caso, o controle sobre o capital é ainda mais explícito que o da renda, pois a distribuição da riqueza incide diretamente sobre o poder de influência nas decisões dentro da empresa.

\footnotetext{
${ }^{36}$ Refere-se ao teste de médias.
} 
Nesse sentido, o Brasil é caracterizado por relações de trabalho consideradas "atomísticas" em que a relação entre os próprios trabalhadores tende a perder a horizontalidade devido à atuação dos sindicatos, os quais são hierarquizados. De forma mais geral, na América Latina, embora a força de trabalho seja mais politizada, há uma tendência de controle da força de trabalho por parte do Estado (ver Schneider, 2009).

De fato, a permanência da relação tradicional entre capital e trabalho constitui-se no cerne das críticas às análises mais otimistas dos dados sobre desigualdade econômica no Brasil. Ao passo que a desigualdade em termos de rendimentos (salários) diminuiu, argumenta-se que a política econômica conservadora e a ordem neoliberal dos governos Collor e FHC foram mantidas de forma a evitar o confronto com o capital (ver Singer, 2012). A divisão de riqueza entre capital e trabalho permanece alta, alimentando controvérsias acerca da suposta diminuição da desigualdade ${ }^{37}$.

Assim, ainda há uma prevalência dos detentores de capital econômico, que possuem mais influência dentro de suas empresas ou firmas em comparação com os trabalhadores alienados do resultado de seu trabalho. Essa hierarquia pode ser uma consequência natural do capitalismo, que concentra o poder político nas mãos de quem detém o poder econômico. Uma das alternativas mais conhecidas a esse tipo de lógica, a Economia Solidária, insere-se no debate sobre participação política ao promover um projeto de emancipação face às hierarquias geradas pela lógica de mercado.

A ideia da autogestão, característica central das cooperativas consideradas "verdadeiras" 38 , incentiva relações mais democráticas, autônomas e participativas entre os cooperados de forma a trazer mais liberdade para os trabalhadores (Galvão e Cifuentes, 2001). Ademais, as decisões são tomadas em conjunto, de forma direta por meio de

\footnotetext{
${ }^{37}$ A mensuração da desigualdade econômica por meio da desigualdade de rendimentos é bastante controversa. Não por acaso recentemente um estudo realizado pelos brasileiros Marcelo Medeiros, Pedro Souza e Fábio Castro se destacou como um dos dez artigos mais lidos do Social Science Research Network. O paper ressaltava que a distribuição de riqueza permanece alta e estável, conclusão advinda por meio de uma análise que considera dados da Receita em vez de usar os habituais dados fornecidos pela PNAD. Ver: Medeiros, Souza e Castro (2014).

${ }^{38}$ Dentro do campo da Economia Solidária, discute-se a natureza dos empreendimentos, pois há muitas ocorrências de alguns que se intitulam "cooperativas", mas não seguem o principio da autogestão, nem o da igualdade entre os trabalhadores (Ver Galvão e Cifuentes, 2001; Singer, 2007). Isso gera um grande problema no momento de buscar incentivos governamentais, visto que não há marco regulatório da economia solidária e, assim, empreendimentos que não seriam considerados solidários devido ao distanciamento dos princípios competem também por tais benefícios. Além disso, há o problema da competição: as cooperativas de economia solidária podem enfrentar problemas ao competir com empresas tradicionais em uma economia de mercado, pois não dispõem das mesmas condições dessas empresas (flexibilização da legislação trabalhista, por exemplo).
} 
assembleias quando possível, ou indireta - mantendo sempre o princípio de igualdade política, mesmo que no sentido restrito referente a cada trabalhador corresponder a um voto (ver Singer, 2007).

Dessa forma, mesmo as decisões que são cabíveis a um conselho representativo visto à inviabilidade de processo direto devido à larga escala estão sujeitas à prestação de contas e atenção por parte de todos os trabalhadores que fazem parte da cooperativa. Nesse ponto, trata-se de um projeto revolucionário: busca-se inverter a lógica tradicional de hierarquia entre capital e trabalho, proporcionando uma democratização da esfera econômica.

Entretanto, a Economia Solidária está vulnerável aos mesmos problemas de assimetrias internas, como no caso do OP: assimetrias podem ser geradas internamente devido a fatores sociais, culturais ou econômicos. É o caso de algumas experiências em Porto Alegre, em que se verificou uma tendência - mesmo que considerada fraca - de verticalização. Algumas associações ainda apresentaram desigualdades em termos de gênero, com poucas mulheres ocupando cargos de direção (ver Locks e Gugliano, 2013).

Havia, também, a percepção de certa divisão do trabalho que propiciava o surgimento de lideranças. Ademais, pessoas com vínculos a partidos e movimentos tendiam a assumir posições de líderes, o que corrobora novamente ao argumento da importância da socialização e acesso a esse tipo de iniciativa. Constatou-se, ainda, que o fato de a maior parte dos empreendimentos ser composta majoritariamente por membros com laços familiares contribuía para assimetrias dentro desses espaços (Locks e Gugliano, 2013).

Destarte, infere-se que tanto hierarquias formais (como no caso do trabalho) quanto informais (como aquela encontrada no interior da estrutura familiar) podem inibir comportamentos democráticos. Isso ocorre possivelmente devido às assimetrias de poder decorrente dessas hierarquias, que constrangem a atuação dos indivíduos em termos de motivação, interesse e senso de eficácia.

Renda e riqueza podem contribuir para a formação dessas hierarquias, pois ambas estão relacionadas com a posição que os indivíduos ocupam em termos materiais e em referência ao status social. Dessa forma, a distribuição de renda/riqueza afeta não apenas o acesso a determinados espaços, mas também a distribuição de poder político no interior deles. 
Por fim, cabe destacar que renda e outros fatores socioeconômicos incidem sobre a efetividade do "treinamento político" desenvolvido nesses locais e, consequentemente, nas potencialidades de cada participante. Se por um lado, a pesquisa sobre o OP corrobora a importância do treinamento de indivíduos para a participação política, por outro ela mostra como o nível educacional incide na efetivação desse treinamento.

Como ilustrado na tabela, pode existir certa relação entre conhecimento das regras/critérios de funcionamento à participação, ao menos discursiva, no Orçamento Participativo. Conhecimento das regras e critérios, por sua vez, está relacionado ao tempo de participação no OP, em que as chances de socialização das regras do jogo são aumentadas (Fedozzi, 2009).

Tabela 5 - Conhecimento das regras e critérios do OP e falar no OP, Porto Alegre.

\begin{tabular}{l|l|c|c|c|c}
\hline \multirow{2}{*}{$\begin{array}{l}\text { Conhecimento das regras e } \\
\text { critérios de funcionamento do OP }\end{array}$} & \multicolumn{5}{|c}{ Costuma Falar no OP } \\
\cline { 3 - 7 } & & Sempre & Quase Sempre & Às vezes & Nunca \\
\hline A maioria das regras & $\mathrm{n}$ & 103 & 66 & 132 & 87 \\
& $\%$ & $\mathbf{6 5 , 2}$ & $\mathbf{6 0 , 6}$ & $\mathbf{4 0 , 1}$ & $\mathbf{1 0 , 2}$ \\
\hline Apenas algumas & $\mathrm{n}$ & 25 & 25 & 104 & 243 \\
& $\%$ & $\mathbf{1 5 , 8}$ & $\mathbf{2 2 , 9}$ & $\mathbf{3 1 , 6}$ & $\mathbf{2 8 , 5}$ \\
\hline Poucas & $\mathrm{n}$ & 16 & 11 & 59 & 185 \\
& $\%$ & $\mathbf{1 0 , 1}$ & $\mathbf{1 0 , 1}$ & $\mathbf{1 7 , 9}$ & $\mathbf{2 1 , 7}$ \\
\hline Não conhece & $\mathrm{n}$ & 14 & 7 & 34 & 339 \\
& $\%$ & $\mathbf{8 , 9}$ & $\mathbf{6 , 4}$ & $\mathbf{1 0 , 3}$ & $\mathbf{3 9 , 7}$ \\
\hline Total & $\mathrm{n}$ & 158 & 109 & 329 & 854 \\
& $\%$ & $\mathbf{1 0 0}$ & $\mathbf{1 0 0}$ & $\mathbf{1 0 0}$ & $\mathbf{1 0 0}$ \\
\hline
\end{tabular}

Fonte: Fedozzi (2009).

O nível educacional é destacado por Fedozzi (2009) como uma variável em relação à apreensão das regras do jogo. Como renda é um fator que incide sobre oportunidades de aquisição de níveis educacionais, infere-se, portanto, seu impacto sobre a apreensão das regras e, por consequência, na participação dentro do OP. Dessa forma, diferenças nas oportunidades de treinamento e, consequentemente, na apreensão das regras de funcionamento causariam desigualdades na participação.

De fato, uma discussão pertinente à adoção de mecanismos de participação é se tais iniciativas se constituem em meros simulacros ou se realmente possuem algum poder efetivo de decisão. Assim como o OP, a Economia Solidária e os Conselhos Gestores não estão imunes à formação de assimetrias em seu anterior, seja devido à desigualdade 
educacional, às diferenças no status socioeconômico ou então à influência de outras variáveis, como gênero e raça.

Vale ressaltar que o OP não se constitui em uma aplicação do mecanismo participativo em si tal como delineado na democracia participativa, mas atua mais propriamente como arena de discussão. Assim, é possível identificar o OP mais aproximadamente de uma iniciativa deliberativa que participativa. Cabe destacar que, nesse aspecto, a separação entre esfera de discussão e de decisão inerente ao deliberacionismo é largamente criticada por alguns autores.

A partir do instante em que há separação clara entre órgãos de discussão e unidades de decisão, os indivíduos não estão exercendo o poder de decidir em si, o que pode configurar em intervenção e contato limitados com o sistema político. De toda forma, renda e riqueza opõem limites tanto à capacidade dos indivíduos de discutir paritariamente quanto no poder de decisão.

Além disso, o OP constitui-se simultaneamente em instância representativa, pois pressupõe a eleição de representantes que assumem funções de liderança. Dessa forma, até mesmo essa iniciativa "participativa" está vulnerável aos problemas inerentes à representação política: o distanciamento entre representantes e representados e a desigualdade de poder político.

Quanto aos efeitos da renda e riqueza nesse contexto, é possível pensar que renda e riqueza podem contribuir para o surgimento de líderes e a diferenciação dele em relação às bases, uma vez que estão relacionadas a fatores que incidem sobre as capacidades dos indivíduos em se destacar politicamente.

No que concerne especificamente à relação entre renda/riqueza e socialização de forma mais geral, a relação entre elas se delineia em três dimensões:

i. Acesso a espaços, instituições e associações: como renda e riqueza condicionam o acesso a determinados espaços físicos, desigualdades econômicas implicam em diferenciais no acesso a esses espaços. Indivíduos com baixa renda teriam menos possibilidades de aproveitar as oportunidades relacionadas ao treinamento desenvolvido nesses tipos de espaços, devido tanto à impossibilidade física de acessá-los quanto à exclusão social. 
ii. Relações sociais dentro de organizações: o mero acesso a instituições e associações ainda seria insuficiente se esses espaços reproduzissem as hierarquias existentes na sociedade. A influência do diferencial de renda e riqueza e consequentemente da posição socioeconômica dos indivíduos na ocupação de cargos importantes ou no prestígio pessoal pode comprometer o princípio de igualdade política, uma vez que a opinião de determinados indivíduos passam a valer mais que a de outros.

iii. Impactos no treinamento: renda está relacionada a outros fatores, como nível educacional. O nível educacional, por sua vez, incide sobre a apreensão de conteúdos importantes à participação dentro dos espaços de socialização, tais como as regras de funcionamento. Dessa forma, diferenças substanciais de renda provavelmente geram diferenças na participação e, por consequência, na influência exercida por diferentes indivíduos.

Os dois primeiros itens descritos acima remetem ao conceito de acessibilidade, a qual está relacionada às barreiras que os indivíduos encontram no acesso a determinados espaços. Tais barreiras não se referem apenas a impedimentos físicos - como falta de condições materiais para se chegar a determinados lugares - mas também a obstáculos sociais. Nesse sentido, a própria percepção de não ser "bem-vindo" ou o estigma social em torno de certos espaços podem contribuir para que algumas pessoas sejam impelidas a não frequentá-los.

Tanto as barreiras físicas quanto as sociais podem estar corelacionadas à renda e à riqueza, uma vez que ambas são determinantes na formação do status social individual, além de prover as condições materiais necessárias ao acesso de qualquer ambiente físico. A hipótese central aqui é, portanto, de que a renda determina o tipo de associação frequentada pelos indivíduos (e, consequentemente, a forma de mobilização política), pois condiciona o acesso desses indivíduos a determinados espaços e o contato com certas instituições e associações.

Um possível teste empírico que poderia ser desenvolvido para verificar tal hipótese abrange a análise do perfil socioeconômico dos membros das associações, mapeadas de acordo com o tipo (associações religiosas, de desporto, profissionais etc.). Embora não fosse um teste definitivo, a pesquisa auxiliaria a construir respostas à questão "a renda gera alguma tendência a participar de tipos específicos de associações?”. 
No que tange especificamente aos mecanismos participativos institucionalizados, embora sejam iniciativas importantes, não basta que a legislação preveja tais mecanismos e que eles estejam institucionalizados no âmbito da gestão governamental; é preciso combater as assimetrias existentes dentro desse tipo de instituição. Propiciar oportunidades equitativas de acesso a esses espaços e relações sociais igualitárias dentro deles constituem-se, portanto, em simultaneamente um imperativo e um desafio no fomento de uma participação política menos desigual.

Sobretudo, a democracia exige mais do que a democratização de espaços institucionalizados, uma vez que esferas informais, tais como a família, são cruciais no desenvolvimento do próprio interesse pela política. Hierarquias construídas no interior desses espaços podem inibir atitudes participativas, pois geram assimetrias de poder decisório, as quais impactam nos comportamentos dos indivíduos.

Dessa forma, pessoas que estão acostumadas a não opinar sobre assuntos no cotidiano ou não tomar parte em processos decisórios na própria casa, na escola, ou no trabalho tendem a acreditar que sua participação individual não mudará nada, preferindo não empreender qualquer esforço nesse sentido.

Tanto renda quanto riqueza podem incidir sobre a construção dessas hierarquias, embora de maneiras distintas. Enquanto a riqueza afeta principalmente os fatores diretamente ligados às relações de trabalho, a renda afeta até as condições físicas de acesso a determinados espaços.

Assim, se houvesse maior equiparação em relação à renda e riqueza e mais pessoas possuem acesso a esses espaços de forma mais igualitária, provavelmente mais pessoas se sentiriam aptas a participar do processo decisório em larga escala. Tal argumento encontrase resumido no quadro seguinte:

Quadro 2 - Mecanismo da socialização/acessibilidade.

\begin{tabular}{|c|c|c|c|c|c|c|}
\hline $\begin{array}{l}\text { Distribuição } \\
\text { mais } \\
\text { igualitária de } \\
\text { renda/riqueza }\end{array}$ & $\begin{array}{l}\text { Mais pessoas } \\
\text { possuem } \\
\text { acesso a } \\
\text { instituições, } \\
\text { organizações } \\
\text { e } \\
\text { associações. }\end{array}$ & $\begin{array}{l}\text { Relações } \\
\text { igualitárias } \\
\text { são } \\
\text { fomentadas } \\
\text { nesses } \\
\text { espaços. }\end{array}$ & $\begin{array}{l}\text { Mais } \\
\text { pessoas } \\
\text { participam } \\
\text { do processo } \\
\text { decisório em } \\
\text { pequena } \\
\text { escala. }\end{array}$ & $\begin{array}{l}\text { Mais pessoas } \\
\text { desenvolvem } \\
\text { habilidades } \\
\text { necessárias } \\
\text { exercício da atividade } \\
\text { política, devido ao } \\
\text { treinamento } \\
\text { propiciado por esses } \\
\text { espaços. }\end{array}$ & $\begin{array}{l}\text { Mais } \\
\text { pessoas } \\
\text { se } \\
\text { envolve } \\
\text { m com a } \\
\text { política. }\end{array}$ & $\begin{array}{l}\text { Mais } \\
\text { pessoas } \\
\text { participam } \\
\text { do processo } \\
\text { decisório } \\
\text { em larga } \\
\text { escala. }\end{array}$ \\
\hline
\end{tabular}

Fonte: Elaboração da autora. 


\subsubsection{Educação e informação}

Tanto educação quanto informação estão ligadas à apreensão de conteúdo e desenvolvimento de capacidades cognitivas, embora sejam dois fatores distintos. Ambas são muitas vezes associadas à palavra "conhecimento". Para os fins desse trabalho, educação refere-se ao nível de instrução formal, operacionalizada nos anos dedicados à escola e na conclusão dos estágios (fundamental, médio e superior), enquanto informação indica dados factuais.

A interação entre educação, informação e democracia faz parte de um debate em torno dos requisitos para o exercício do autogoverno. Se, por um lado, pode parecer óbvio que cidadãos bem informados e com certo nível educação tomem decisões mais apropriadas aos seus interesses, por outro, essa perspectiva está longe de fazer parte de um consenso na Ciência Política.

Dessa forma, há autores que defendem que a informação é necessária para que os eleitores tomem decisões adequadas (ver Luskin, Fishkin \& Jowell, 2002; Delli Carpini \& Keeter, 1996), enquanto outros ressaltam certa presunção nessa assertiva, destacando que os eleitores não precisam de tanto conhecimento para tomar suas decisões (ver Lupia \& McCubbins, 2000).

Na teoria democrática, a educação e a informação são vistas majoritariamente como recursos relacionados à aquisição de capital político. Para a abordagem liberal, a educação é vista como um meio de adquirir capacidades necessárias ao processamento de informação, a qual é tida como um recurso necessário à atividade política e principalmente à tomada de decisões. A informação, tal como concebida por Downs (1999 [1957]), incide sobre a incerteza, a qual está associada à confiança dos indivíduos quando tomam suas decisões.

A informação está presente no deliberacionismo, mas em detrimento da consideração acerca da importância das assimetrias em relação ao exercício do poder. Isso ocorre devido à suposição do cenário de "fala ideal”, em que as trocas discursivas gerariam uma distribuição igualitária da informação, o que está longe de corresponder à situação concreta.

Dessa forma, nota-se que tanto o liberalismo quanto o deliberacionismo são limitados no tocante aos impactos psicológicos da educação e da informação nos 
indivíduos. Na democracia participativa, por outro lado, a educação está relacionada ao próprio processo de socialização dos indivíduos, fundamental na construção do interesse dos indivíduos e no senso de capacidade de intervenção no sistema político.

De fato, o argumento geral em torno da relação positiva entre educação e informação de um lado e democracia de outro está centrado na suposição de que a democracia funciona melhor quando cidadãos estão politicamente informados. Dessa maneira, quanto mais igualitariamente a informação é distribuída, mais provavelmente o governo agirá em favor do interesse público, pois a democracia será mais responsável e responsiva (Delli Carpini \& Keeter, 1996).

Nesse sentido, "como, o que e quanto" os cidadãos sabem sobre política (distribuição do conhecimento) depende tanto de características individuais quanto forças sistêmicas (Delli Carpini \& Keeter, 1996). Há, portanto, uma interação entre fatores considerados internos ao indivíduo - como habilidade e motivação - e elementos exógenos, principalmente os indicadores relacionados ao status socioeconômico (SES).

Entretanto, a separação entre fatores internos e externos aos indivíduos ainda contribui para uma naturalização inadequada das disposições consideradas como "individuais", tendo em vista que esses fatores internos são primordialmente produtos sociais internalizados.

De qualquer forma, uma vez que nível educacional, renda, e riqueza fazem parte dos indicadores de status socioeconômico, é possível pensar em como eles se relacionam. A informação é, assim, parcialmente determinada pelo acesso a recursos sociais e econômicos, o que contribui para a reprodução das desigualdades na esfera pública (Delli Carpini \& Keeter, 1996).

De forma semelhante, Luskin, Fishkin e Jowell (2002) enfatizam a importância do contexto na distribuição de oportunidades de aquisição de informação e, consequentemente, na formação de opiniões políticas. Dessa forma, tal como ocorre com a socialização, há novamente uma questão de acesso: indivíduos com diferentes características socioeconômicas possuem oportunidades distintas de acesso à informação.

De fato, socialização, educação e informação são fatores que estão substancialmente interligados, uma vez que o acesso a determinados locais estabelece as trocas discursivas e os tipos de informação aos quais os indivíduos terão acesso. Por outro 
lado, o nível educacional incide diretamente na capacidade de apreensão de certos conteúdos, como as regras do jogo, cujo conhecimento é necessário para fomentar a participação política.

Renda e riqueza incidem sobre o acesso a determinados espaços assim como a oportunidades de aquisição de níveis educacionais, e, consequentemente, no contato com tipos diversos de informações e conteúdos políticos. É razoável supor que os rendimentos recebidos por cidadãos e cidadãs afetem, por exemplo, a capacidade de adquirir certos materiais informativos (meios de comunicação como aparelhos de televisão ou computadores, por exemplo, embora eles estejam mais popularizados atualmente) ou na possibilidade de pagar por escolas de qualidade.

Nesse sentido, não é novidade que o contexto brasileiro é marcado por grandes desigualdades educacionais. A tabela 6 ilustra essa desigualdade, pois mostra que a maior proporção de pessoas que não frequentam escolas corresponde ao grupo que contém os $20 \%$ mais pobres da população ( $1^{\circ}$ quinto), enquanto a proporção menor, para todas as regiões do Brasil, encontra-se no grupo que contém os $20 \%$ mais ricos ( $5^{\circ}$ quinto).

Tabela 6 - Proporção de pessoas de 18 a 24 anos de idade, com menos de 11 anos de estudo e que não frequentavam escola (\%)

\begin{tabular}{|c|c|c|c|c|c|c|}
\hline \multirow{3}{*}{ Grandes Regiões } & \multicolumn{6}{|c|}{$\begin{array}{l}\text { Proporção de pessoas de } 18 \text { a } 24 \text { anos de idade, com menos de } \\
\qquad 11 \text { anos } \\
\text { de estudo e que não frequentavam escola (\%) }\end{array}$} \\
\hline & \multirow{2}{*}{ Total (1) } & \multicolumn{5}{|c|}{$\begin{array}{l}\text { Quintos de rendimento mensal familiar per capita } \\
\text { nacional }\end{array}$} \\
\hline & & $\begin{array}{c}10 \\
\text { quinto }\end{array}$ & $\begin{array}{c}20 \\
\text { quinto } \\
\end{array}$ & $\begin{array}{c}\text { 3o } \\
\text { quinto }\end{array}$ & $\begin{array}{c}\text { 4을 } \\
\text { quinto }\end{array}$ & $\begin{array}{c}50 \\
\text { quinto } \\
\end{array}$ \\
\hline Brasil & 32.3 & 53.8 & 43.8 & 32.5 & 22.9 & 10.2 \\
\hline Norte & 36.7 & 54.2 & 41.1 & 29.9 & 22.2 & 10.4 \\
\hline Nordeste & 38.0 & 52.6 & 41.9 & 29.6 & 19.3 & 7.8 \\
\hline Sudeste & 27.1 & 54.2 & 43.4 & 30.8 & 21.0 & 9.2 \\
\hline Sul & 33.2 & 63.9 & 53.6 & 41.9 & 29.0 & 12.6 \\
\hline Centro-Oeste & 30.9 & 50.9 & 48.6 & 37.1 & 26.3 & 12.0 \\
\hline
\end{tabular}

Fonte: IBGE, Pesquisa Nacional por Amostra de Domicílios 2012. (1) Inclusive pessoas sem declaração de rendimento familiar per capita.

De forma semelhante, as médias de anos de estudo são maiores para os $20 \%$ mais ricos da população, como demonstra a tabela 7 , que também se refere à faixa etária corresponde à escala de 18 a 24 anos. 
Tabela 7 - Média de anos de estudo das pessoas de 18 a 24 anos de idade por quintos de rendimento mensal familiar per capita nacional

\begin{tabular}{|c|c|c|c|c|c|c|}
\hline \multirow{3}{*}{ Grandes Regiões } & \multicolumn{6}{|c|}{ Média de anos de estudo das pessoas de 18 a 24 anos de idade } \\
\hline & \multirow{2}{*}{ Total (1) } & \multicolumn{5}{|c|}{$\begin{array}{l}\text { Quintos de rendimento mensal familiar per capita } \\
\text { nacional }\end{array}$} \\
\hline & & 10 quinto & 20 quinto & 30 quinto & 40 quinto & 5 o quinto \\
\hline Brasil & 9.6 & 7.9 & 8.7 & 9.5 & 10.4 & 11.7 \\
\hline Norte & 8.9 & 7.5 & 8.5 & 9.2 & 10.1 & 11.3 \\
\hline Nordeste & 8.9 & 7.7 & 8.6 & 9.5 & 10.5 & 11.8 \\
\hline Sudeste & 10.2 & 8.4 & 9.0 & 9.7 & 10.4 & 11.7 \\
\hline Sul & 10.1 & 8.2 & 8.6 & 9.4 & 10.2 & 11.6 \\
\hline Centro-Oeste & 10.0 & 8.6 & 8.9 & 9.4 & 10.2 & 11.6 \\
\hline
\end{tabular}

Fonte: IBGE, Pesquisa Nacional por Amostra de Domicílios 2012.

(1) Inclusive pessoas sem declaração de rendimento familiar per capita.

Isso ocorre não apenas devido aos custos associados a frequentar escolas (mensalidade, material, deslocamento etc.), mas também porque possivelmente a falta de rendimento familiar suficiente para a sobrevivência exige que as pessoas entre a faixa etária indicada (18-24 anos) dediquem-se integralmente ao trabalho formal, informal ou doméstico, em ajuda aos familiares.

Dessa forma, membros de famílias com baixa renda possuem menos condições de se concentrar nos estudos, uma vez que precisam ajudar financeiramente seus familiares, o que demanda tempo e dedicação.

A educação, por sua vez, incide sobre a participação política de várias formas. Primeiramente, como mencionado em momento anterior, a educação está relacionada com a apreensão de certos conteúdos, como regras de funcionamento, e aquisição de capacidades cognitivas. Como demonstrado pela pesquisa realizada sobre o OP em Porto Alegre, o nível de ensino possui relação tanto com o conhecimento das regras de funcionamento do OP quanto com a participação oral direta.

A tabela 8 mostra os dados relativos ao conhecimento sobre regras e critérios de funcionamento do OP, de acordo com o tempo de participação na iniciativa e o nível de ensino, enquanto a tabela 9 traz respostas dos entrevistados relativas à frequência de fala no OP. 
Tabela 8: Conhecimento das regras e critérios por tempo de OP e nível de ensino

\begin{tabular}{|c|c|c|c|c|c|c|c|c|}
\hline \multirow{2}{*}{\multicolumn{2}{|c|}{$\begin{array}{l}\text { Conhecimentos das } \\
\text { regras e critérios de } \\
\text { funcionamento do OP }\end{array}$}} & \multicolumn{4}{|c|}{ tempo de OP } & \multicolumn{3}{|c|}{ nível de ensino } \\
\hline & & \multirow{2}{*}{$\begin{array}{c}1 \text { ano } \\
22\end{array}$} & \multirow{2}{*}{$\begin{array}{c}2 \text { a } 4 \\
\text { anos } \\
98\end{array}$} & \multirow{2}{*}{$\begin{array}{c}5 \text { a } 7 \\
\text { anos } \\
94\end{array}$} & \multirow{2}{*}{$\begin{array}{c}8 \text { anos } \\
\text { ou mais } \\
153\end{array}$} & \multirow{2}{*}{$\begin{array}{c}\text { fundamental } \\
110\end{array}$} & \multirow{2}{*}{$\begin{array}{c}\text { médio } \\
152\end{array}$} & \multirow{2}{*}{$\begin{array}{c}\text { superior } \\
123\end{array}$} \\
\hline a maioria das & $\mathrm{n}$ & & & & & & & \\
\hline regras & $\%$ & 11,1 & 25,9 & 47,7 & 64,0 & 14,7 & 30,2 & 53,5 \\
\hline \multirow{2}{*}{ apenas algumas } & $\mathrm{n}$ & 66 & 144 & 60 & 58 & 190 & 154 & 56 \\
\hline & $\%$ & 33,2 & 38,0 & 30,5 & 24,3 & 25,4 & 30,6 & 24,3 \\
\hline \multirow{2}{*}{ Poucas } & $\mathrm{n}$ & 46 & 81 & 30 & 23 & 145 & 101 & 28 \\
\hline & $\%$ & 23,1 & 21,4 & 15,2 & 9,6 & 19,4 & 20,0 & 12,2 \\
\hline \multirow{2}{*}{ não conhece } & $\mathrm{n}$ & 65 & 56 & 13 & 5 & 304 & 97 & 23 \\
\hline & $\%$ & 32,7 & 14,8 & 6,6 & 2,1 & 40,6 & 19,2 & 10,0 \\
\hline \multirow{2}{*}{ Total } & $\mathrm{n}$ & 199 & 379 & 197 & 239 & 749 & 504 & 230 \\
\hline & $\%$ & 100 & 100 & 100 & 100 & 100 & 100 & 100 \\
\hline
\end{tabular}

Fonte: Fedozzi (2009).

Tabela 9: Propensão a falar nas reuniões do OP, por tempo de OP e nível de ensino

\begin{tabular}{l|c|c|c|c|c|c|c|c}
\hline \multicolumn{2}{l}{$\begin{array}{l}\text { Costuma se inscrever } \\
\text { para falar nas reuniões } \\
\text { que tratam do OP }\end{array}$} & \multicolumn{4}{c|}{ tempo de OP } & \multicolumn{3}{c}{ nível de ensino } \\
\cline { 2 - 10 } Sempre & 1 ano & $\begin{array}{c}2 \text { a } 4 \\
\text { anos }\end{array}$ & $\begin{array}{c}5 \text { a 7 } \\
\text { anos }\end{array}$ & $\begin{array}{c}8 \text { anos } \\
\text { ou mais }\end{array}$ & fundamental & médio & superior \\
\hline \multirow{2}{*}{ quase sempre } & $\mathrm{n}$ & 11 & 31 & 32 & 58 & 62 & 62 & 34 \\
& $\%$ & $\mathbf{5 , 5}$ & $\mathbf{8 , 2}$ & $\mathbf{1 6 , 2}$ & $\mathbf{2 4 , 2}$ & $\mathbf{8 , 4}$ & $\mathbf{1 2 , 5}$ & $\mathbf{1 5 , 0 1 4}$ \\
\hline \multirow{2}{*}{ às vezes } & $\mathrm{n}$ & 14 & 20 & 17 & 41 & 37 & 42 & 28 \\
& $\%$ & $\mathbf{7 , 0}$ & $\mathbf{5 , 3}$ & $\mathbf{8 , 6}$ & $\mathbf{1 7 , 1}$ & $\mathbf{5 , 0}$ & $\mathbf{8 , 5}$ & $\mathbf{1 2 , 3}$ \\
\hline \multirow{2}{*}{ Nunca } & $\mathrm{n}$ & 44 & 94 & 60 & 78 & 149 & 123 & 61 \\
& $\%$ & $\mathbf{2 2}$ & $\mathbf{2 4 , 9}$ & $\mathbf{3 0 , 3}$ & $\mathbf{3 2 , 5}$ & $\mathbf{2 0 , 3}$ & $\mathbf{2 4 , 8}$ & $\mathbf{2 6 , 9}$ \\
\hline \multirow{2}{*}{ Total } & $\mathrm{n}$ & 131 & 233 & 89 & 63 & 486 & 269 & 104 \\
& $\%$ & $\mathbf{6 5 , 5}$ & $\mathbf{6 1 , 6}$ & $\mathbf{4 4 , 9}$ & $\mathbf{2 6 , 3}$ & $\mathbf{6 6 , 2}$ & $\mathbf{5 4 , 2}$ & $\mathbf{4 5 , 8}$ \\
\hline
\end{tabular}

Fonte: Fedozzi (2009).

Sobretudo, a escola ${ }^{39}$ é um espaço de socialização importante, uma vez que auxilia no desenvolvimento de capacidades necessárias à atividade política, além de estabelecer certas redes de contatos.

Não por acaso, verifica-se uma tendência de maior participação em ações políticosociais de indivíduos com mais níveis educacionais, em comparação também à média geral do Brasil (Tabela 10) ${ }^{40}$.

\footnotetext{
${ }^{39}$ Escola e nível de instrução constituem-se em variáveis de tipo “proxy” para capacidades cognitivas, sobre as quais teríamos dificuldades em obter dados.

${ }^{40}$ Outros fatores podem incidir sobre a atuação de acordo com os tipos de mobilização. Por exemplo, é razoável que a média de participação de estudantes em greves seja baixa, devido a essa forma de mobilização ser típica do contexto de trabalho.
} 
Tabela 10 - Mobilização política e escolaridade, médias do Brasil (2006)

\begin{tabular}{|c|c|c|c|c|c|}
\hline $\begin{array}{l}\text { Ação } \quad \text { Político- } \\
\text { Social }\end{array}$ & $\begin{array}{l}\text { Até a 4a Série } \\
\text { (atual 5o ano) do } \\
\text { Ensino } \\
\text { Fundamental }\end{array}$ & $\begin{array}{l}\text { Da 5a a 8a séries } \\
\text { (atuais 6o e 9o } \\
\text { anos) do Ensino } \\
\text { Fundamental }\end{array}$ & Ensino Médio & Ensino Superior & Brasil \\
\hline $\begin{array}{lr}\text { Assinar } & \text { petição ou } \\
\text { fazer } & \text { abaixo- } \\
\text { assinado } & \\
\end{array}$ & 0,90 & 1,11 & 1,28 & 1,65 & 1,15 \\
\hline Boicotar produtos & 0,34 & 0,52 & 0,57 & 0,81 & 0,51 \\
\hline $\begin{array}{ll}\text { Participar } & \text { em } \\
\text { manifestações } & \\
\end{array}$ & 0,54 & 0,70 & 0,92 & 1,15 & 0,76 \\
\hline $\begin{array}{ll}\text { Participar } & \text { em } \\
\text { comícios ou em } \\
\text { reuniões políticas }\end{array}$ & 0,95 & 1,05 & 1,19 & 1,23 & 1,07 \\
\hline $\begin{array}{l}\text { Contactar políticos } \\
\text { para expressar sua } \\
\text { opinião }\end{array}$ & 0,43 & 0,58 & 0,69 & 0,89 & 0,60 \\
\hline $\begin{array}{l}\text { Dar dinheiro para } \\
\text { causas públicas }\end{array}$ & 0,53 & 0,64 & 0,65 & 0,75 & 0,61 \\
\hline $\begin{array}{lr}\begin{array}{l}\text { Contactar } \\
\text { aparecer }\end{array} & \text { ou } \\
\text { mídias } & \\
\end{array}$ & 0,30 & 0,43 & 0,53 & 0,74 & 0,45 \\
\hline $\begin{array}{ll}\text { Participar de fórum } \\
\text { ou de grupo de } \\
\text { discussão } & \text { na } \\
\text { internet } & \end{array}$ & 0,20 & 0,40 & 0,54 & 1,01 & 0,44 \\
\hline Participar de greve & 0,30 & 0,50 & 0,63 & 0,89 & 0,51 \\
\hline
\end{tabular}

Fonte: Pesquisa Observatório das Metrópoles, IUPERJ, ICS-UL, ISRP (2006-2008) apud Azevedo, Santos Júnior e Ribeiro (2009).

Escala: (0) "Nunca o faria", (1) "Não fez, mas poderia ter feito", (2) "Fez em anos anteriores", (3) "Fez no último ano".

Assim, distribuição de rendimentos estaria relacionada à distribuição das oportunidades em termos de acesso à educação, que se relaciona com a participação política por propiciar aprendizado e desenvolvimento de capacidades cognitivas, além de se constituir em uma esfera de socialização em que os indivíduos passam período significante de suas vidas.

Já a riqueza, uma vez que está relacionada com ocupação de cargos hierárquicos, pode possibilitar acesso diferenciado a certos tipos de informação, não apenas no contexto empresarial, mas nas próprias possibilidades de contato direto com o governo (o que será abordado com mais profundidade no próximo tópico).

Sobretudo, a concentração de riqueza relaciona-se à posição socioeconômica ocupada pelo indivíduo, o que corrobora para como certos sentidos são atribuídos à informação apreendida. Isso ocorre porque a posição socioeconômica contribui para a construção de certas visões de mundo, o que impacta no conjunto de signos do qual dispõem as pessoas no momento da interpretação da informação adquirida. 
Dessa forma, renda e riqueza afetam a forma com a qual a informação é adquirida e também recebida em termos de interpretação, enquanto informação relaciona-se com oportunidades de participação política, seja direta ou indireta.

A conclusão de estudos como o de Delli Carpini \& Keeter (1996) e o de Luskin, Fishkin e Jowell (2002) é de que "quanto mais informação, melhor", em que a quantidade de informação é consequência dos contextos aos quais os indivíduos pertencem. Entretanto, os trabalhos deixam de lado a questão da qualidade e do tipo da informação, temáticas que não são problematizadas.

Nesse sentido, aborda-se um tipo específico de informação: a informação política. Com a ampliação do fluxo de informações, devido em grande parte à expansão das novas tecnologias como a internet, o acesso à informação política pode estar comprometido justamente pela dificuldade de seleção do conteúdo. Por outro lado, as pessoas podem ter acesso a conteúdos políticos secundariamente, por meio de veículos cujo tema principal não é a política.

Cabe destacar também o papel do viés da informação adquirida, principalmente quando essa informação tem impacto relevante na escolha política dos eleitores e das eleitoras. No Brasil, essa questão é particularmente importante devido à existência de dois tipos de semi-monopólios: o primeiro se trata da preponderância da televisão sobre os demais de meio de comunicação e o segundo refere-se ao domínio de uma emissora de televisão específica no complexo denominado de "grande mídia".

Como demonstra a tabela 11 , por meio dos percentuais relacionados à quantidade de pessoas que afirmam ter a televisão como fonte de informação que mais ajuda a decidir em que votar, a influência desse meio de comunicação ainda é muito alta. Embora tais percentuais sejam crescentes conforme diminuam a renda e a escolaridade, eles se mantêm como os mais altos em todas as categorias. 
Tabela 11 - Fonte de informação mais importante na decisão do voto (2010)

\begin{tabular}{|c|c|c|c|c|c|c|c|c|c|c|c|c|c|c|}
\hline \multirow{2}{*}{$\begin{array}{l}\text { Fonte de } \\
\text { informação } \\
\text { que mais } \\
\text { ajuda a } \\
\text { decidir em } \\
\text { quem votar } \\
\text { - 1a opção } \\
\text { (\%) }\end{array}$} & \multirow[t]{2}{*}{ TOTAL } & \multicolumn{5}{|c|}{ Idade } & \multicolumn{4}{|c|}{ Escolaridade } & \multicolumn{4}{|c|}{$\begin{array}{c}\text { Renda familiar } \\
\text { (salários mínimos) }\end{array}$} \\
\hline & & $\begin{array}{c}16 a \\
24\end{array}$ & $\begin{array}{c}25 a \\
29\end{array}$ & $\begin{array}{c}30 a \\
39\end{array}$ & $\begin{array}{c}40 a \\
49\end{array}$ & $\begin{array}{l}50 \mathrm{e} \\
\text { mais }\end{array}$ & $\begin{array}{l}\text { Até } \\
4 \underline{a}\end{array}$ & $\begin{array}{c}5 \mathrm{a} a \\
8 \underline{a}\end{array}$ & $\begin{array}{l}\text { Ensino } \\
\text { Médio }\end{array}$ & $\begin{array}{l}\text { Ensino } \\
\text { Superior }\end{array}$ & $\begin{array}{c}\text { Até } \\
1\end{array}$ & 1 a 2 & 2 a 5 & $\begin{array}{l}\text { Mais } \\
\text { de } 5\end{array}$ \\
\hline$N$ & 2002 & 411 & 253 & 432 & 386 & 520 & 573 & 455 & 687 & 287 & 262 & 681 & 720 & 249 \\
\hline Televisão & 72 & 63 & 70 & 74 & 69 & 79 & 84 & 75 & 68 & 52 & 75 & 79 & 70 & 53 \\
\hline $\begin{array}{l}\text { Conversas } \\
\text { com } \\
\text { parentes, } \\
\text { amigos e } \\
\text { colegas de } \\
\text { trabalho }\end{array}$ & 2 & 3 & 3 & 3 & 3 & 2 & 3 & 3 & 2 & 1 & 6 & 2 & 2 & 2 \\
\hline Rádio & 4 & 3 & 3 & 3 & 5 & 5 & 4 & 5 & 4 & 2 & 6 & 4 & 4 & 3 \\
\hline Jornal & 3 & 4 & 4 & 3 & 3 & 2 & 1 & 4 & 4 & 5 & 3 & 3 & 3 & 5 \\
\hline Internet & 12 & 21 & 13 & 12 & 12 & 3 & 2 & 7 & 15 & 33 & 5 & 6 & 14 & 29 \\
\hline $\begin{array}{l}\text { Outros } \\
\text { meios }\end{array}$ & 1 & 1 & 2 & 1 & 1 & 1 & 0 & 1 & 2 & 2 & 1 & 1 & 1 & 4 \\
\hline $\begin{array}{l}\text { Nenhum } \\
\text { destes/ } \\
\text { Não se } \\
\text { mantém } \\
\text { informado/ } \\
\text { Não sabe/ } \\
\text { Não } \\
\text { respondeu }\end{array}$ & 6 & 4 & 5 & 4 & 8 & 7 & 6 & 5 & 6 & 6 & 5 & 6 & 6 & 5 \\
\hline
\end{tabular}

Fonte: Resende e Chagas (2011), mediante dados de pesquisa realizada pelo IBOPE.

Embora fosse necessário um teste estatístico para afirmações mais conclusivas da Tabela 11, os dados ilustram que - comparativamente a outras fontes específicas - a televisão possui influência substantiva, mesmo entre os extratos que possuem mais anos de estudo. Entretanto, os dados podem ilustrar algumas tendências: a televisão foi destacada mais vezes pelos extratos correspondentes à menor renda e ao menor nível de instrução, enquanto meios como jornal e internet estão mais presentes nas camadas referentes à maior renda e ao maior nível de instrução.

Há, contudo, um aumento na utilização da internet em todos os extratos, como mostram Resende e Chagas (2011). Os autores destacam a utilização da internet não apenas pelos candidatos e especialistas contratados, mas também pelas diversas redes de eleitores, os quais foram responsáveis por ampliar a circulação massivamente de apoio e ataques às candidaturas. Essa situação foi ainda mais evidente nas eleições de 2014, em que diversos debates foram transmitidos pela rede em tempo real. 
A praticidade e o grande alcance dos meios digitais corroboram para que eles atuem ativamente na formação e divulgação de opiniões, constituindo-se em uma dimensão importante das esferas públicas disponível. Não por acaso, a rede social Facebook desempenhou um papel fundamental nas manifestações de Junho no Brasil, cuja convocatória para protesto ocorreu majoritariamente no meio virtual - o que possibilitou a congregação de muitas pessoas que sequer se conheciam.

Ainda assim, podemos afirmar que a televisão desempenha um papel importante no fluxo de informações. Uma evidência disso é o número de aparelhos encontrados em domicílios em comparação com outras fontes ${ }^{41}$. Além disso, as novas mídias digitais são frequentemente utilizadas para reproduzir o conteúdo previamente divulgado na mídia tradicional.

Nesse sentido, vale lembrar que grande parte do conteúdo disponível em redes sociais também encontra limites provenientes das redes de contatos reais das quais as pessoas fazem parte e dos próprios filtros de pesquisa utilizados pelos mecanismos de busca e feed de notícias. Esses fatores podem contribuir para a diminuição da pluralidade do conteúdo ao qual as pessoas possuem acesso imediato, comprometendo a total liberdade na rede.

Assim, embora as mídias digitais representem possibilidades de resignificação de conteúdos, essas oportunidades ainda estão limitadas pelo poder de "formação de agenda" dos grandes veículos e dos próprios meios sociais nos quais estão inseridos os indivíduos. Isso significa que grande parte dos itens discutidos nas mídias digitais provavelmente já passou pela exposição nos veículos tradicionais, o que pode constituir em grande limitação desses formatos em renovar e democratizar o fluxo de informações.

Cabe destacar também que o acesso aos meios de comunicação não é composto por categorias unitárias, pressupondo algum tipo de escala: ao passo que indivíduos dispõem de aparelhos de televisão, eles podem ainda dispor de canais de TV aberta ou a cabo, conforme suas condições econômicas. De forma semelhante, ter acesso a um computador não significa necessariamente utilizar a internet, enquanto, por outro lado, a rede pode ser acessada através de outros meios, notadamente a internet móvel em aparelhos portáteis.

\footnotetext{
${ }^{41}$ Dados podem ser visualizados aqui: <http://www.teleco.com.br/pnad.asp>.
} 
Um fator que possivelmente tem grande impacto na utilização dos meios de comunicação constitui-se nas ferramentas cognitivas das quais dispõem os indivíduos. Isso significa que capacidades como apreensão de idiomas e nível de escolaridade podem afetar a relação dos indivíduos com os meios de comunicação. Algumas páginas da rede, por exemplo, estão disponíveis apenas em determinados idiomas, dificultando o acesso por parte da população.

Seria necessário ainda indagar se renda/riqueza possui uma relação positiva ou negativa com a capacidade de influência dos meios de comunicação, tendo em vista não apenas o acesso, mas a confiança que as pessoas detêm nesses veículos.

As tendências nos usos desses meios podem ser, portanto, consequência do acesso diferenciado à escola, aos espaços de socialização e da confiança que as pessoas possuem nesses veículos, além do acesso aos meios em si segundo a escala mencionada anteriormente. Todos esses fatores podem ser presumidamente influenciados pela distribuição desigual de recursos econômicos, ou pelo senso de eficácia em relação à apreensão de certos conteúdos, que estaria associado ao nível de instrução. Nesse sentido, a situação no Brasil e na América Latina de forma geral é de uma

[...] combinação entre a grande penetração da mídia eletrônica de massa, em níveis que se aproximam aos dos países desenvolvidos, com a precária cobertura da escola, que muitas vezes cumpre mal sua tarefa de socialização de conhecimentos e exclui um largo contingente da população [...] (Miguel, 2004: $105)$.

Observa-se, portanto, que o papel que a informação exerce na participação política não se limita à relação entre mídia e vínculo eleitoral. Outra dimensão importante é a função que a informação ocupa na construção de preferências, opiniões e interesses. Tratase de um aspecto multifacetado, uma vez que a construção é consequência da interação de diversos fatores, que vão desde o acesso a determinados espaços à influência mais propriamente direta da mídia.

Isso significa que a interação entre variáveis como classe social, nível de instrução, sexo, raça, entre outras, resultam em diferenças nas formas variadas com as quais as mesmas informações levam a graus de atenção e sentidos diferentes para indivíduos situados em posições sociais distintas (ver Biroli \& Miguel, 2013). Nesse sentido, vale 
destacar que não há apenas uma esfera pública - como o pensamento habermasiano pode equivocadamente levar a crer - mas várias, compostas por grupos distintos.

Há uma série de formas distintas com as quais as pessoas podem acessar a vida pública e uma infinidade de arenas discursivas. De forma semelhante, a palavra "público" pode ser utilizada mais apropriadamente no plural, uma vez que existem vários públicos em vez de um só. A esfera pública burguesa, nesse contexto, foi importante na substituição de um tipo de dominação, baseada na obediência à força superior, para outra - baseada no acordo, mas também em novas formas de repressão (Fraser, 1990).

Disso decorre que indivíduos que ocupam posições socioeconômicas diferentes fazem parte de distintas arenas públicas e, portanto, adquirem significações também diversas - de acordo com a influência de uma série de variáveis, como as já citadas. Nesse sentido, as opiniões e as formas de ação dependem ao menos, em parte, dos recursos econômicos aos quais eles possuem acesso.

A aquisição de informação e o nível educacional também afetam a capacidade de ação, visto que a mobilização torna-se possivelmente mais fácil ou ao menos mais tangível para aqueles que conhecem as regras e o funcionamento do sistema político. Por exemplo, a Constituição brasileira de 1988 traz alguns mecanismos de participação direta ${ }^{42}$, mas para utilizá-los, é necessário saber os procedimentos, embora esse conhecimento ainda não baste para promover a participação política.

Cabe destacar que o sistema eleitoral brasileiro não é um dos mais simples, o que contribui para que haja maior exigência no que tange à informação e educação para a participação política. Nesse sentido, o pensamento de Schumpeter parte da assertiva de que os indivíduos são racionais apenas em relação a questões privadas pela proximidade que elas têm com seus respectivos cotidianos.

\footnotetext{
${ }^{42}$ De forma geral Art. 14, incisos I, II, III. Mas destaco aqui a possibilidade de apresentar projeto de inciativa popular, que requer o apoio de $1 \%$ do eleitorado distribuído em pelo menos cinco Estados com no mínimo $0,3 \%$ de eleitores de cada um deles (Art. $61, \S 2^{\circ}$, C.F.). Além desses requisitos, o projeto passa por todo o processo de tramitação no Congresso, que exige acompanhamento e pressão por parte dos interessados, além de substantivo apoio político.
} 
Entretanto, o interesse pelas questões privadas não advém apenas de uma característica inata dos indivíduos, uma vez que o nível de racionalidade ${ }^{43}$ que os indivíduos apresentam é também consequência do contexto social e da experiência.

Assim, é plausível supor que pessoas que tenham menos informação e conhecimento sobre política não apenas deixem de desenvolver algumas habilidades necessárias à participação, mas também se sintam menos capazes de agir por não saber "como a política funciona".

Ocorre, portanto, um distanciamento em que cidadãos e cidadãs não se sentem "próximos" ao sistema político, visto como algo intangível ou inalcançável. Informação e educação são dois fatores importantes que podem contribuir ou mitigar o distanciamento entre cidadãos e sistema político.

Em suma, a informação afeta a participação política através de duas formas: primeiramente devido ao seu papel na construção de opiniões, interesses e capacidades, o que incide sobre a motivação e aptidão dos indivíduos a se engajar em atividades políticas; em segundo lugar, por meio dos seus impactos no vínculo eleitoral entre representantes e representados, em que as diversas fontes existentes de informação afetam as escolhas políticas dos cidadãos e as possibilidades de relacionamento com os escolhidos.

Distribuição de renda e riqueza, por sua vez, possui impacto na aquisição de informação tanto devido à questão do acesso físico ao material (possibilidade de adquirir revistas ou meios de comunicação ou formação de redes de contato) quanto aos enquadramentos diferenciados atribuídos às diversas visões de mundo de acordo com a posição socioeconômica dos indivíduos.

Nota-se, portanto, que há visões consideradas hegemônicas e o tratamento diferenciado concedido a essas visões, principalmente pela "grande mídia", depende em certa medida de fatores socioeconômicos como renda e riqueza, uma vez que ambos estimulam o status social e a prevalência de certos padrões culturais em detrimento de outros.

\footnotetext{
${ }^{43}$ A própria delimitação de "o que é ou não" racional é controversa. Por exemplo, há inúmeras críticas quanto à suposta "compra de votos" de programas sociais como o "Bolsa Família". O enquadramento geralmente veiculado é de que o voto exclusivamente devido a essa política é considerado irracional. Porém, se utilizamos o conceito clássico de racionalidade da Ciência Política, de vinculação entre meios e fins, uma família beneficiária que vota devido ao Programa pode ser considerada racional.
} 
Educação e socialização, que são outros fatores afetados pela distribuição de renda e riqueza, estão intrinsecamente relacionadas à forma com a qual dados factuais são recebidos e processados, uma vez que delimitam o contexto social na qual os indivíduos estão inseridos. Esse argumento pode ser resumido conforme o seguinte quadro:

Quadro 3 - Mecanismo da informação/educação

\begin{tabular}{|c|c|c|c|c|}
\hline $\begin{array}{l}\text { Distribuição } \\
\text { mais igualitária } \\
\text { de } \\
\text { renda/riqueza }\end{array}$ & $\begin{array}{l}\text { Mais pessoas } \\
\text { possuem acesso a } \\
\text { escolas e meios de } \\
\text { comunicação }\end{array}$ & $\begin{array}{l}\text { Pessoas adquirem mais } \\
\text { capacidades cognitivas } \\
\text { necessárias } \\
\text { exercício de atividades } \\
\text { políticas. }\end{array}$ & $\begin{array}{l}\text { Mais pessoas } \\
\text { se envolvem } \\
\text { com a política. }\end{array}$ & $\begin{array}{lr}\text { Mais } & \text { pessoas } \\
\text { participam } & \text { do } \\
\text { processo } & \text { decisório } \\
\text { (maior } & \text { igualdade } \\
\text { política). } & \end{array}$ \\
\hline
\end{tabular}

Fonte: elaboração da autora.

Vale ressaltar ainda que informação, educação e socialização possuem impactos até mesmo na construção do "gosto" e do interesse pela política, contribuindo novamente para o senso de proximidade que os cidadãos e cidadãs possuem em relação ao sistema político.

\subsection{Canais de influência política}

Até o momento, os tópicos anteriores trataram da relação entre a distribuição de renda/riqueza e democracia de forma a abordar mecanismos associados a oportunidades de participação, as quais estão associadas mutuamente a atributos individuais dos cidadãos e cidadãs, como capacidade e motivação. Os efeitos da renda e da riqueza não se limitam, porém, às capacidades individuais, mas incidem, sobretudo, na determinação de quais tipos de relações podem existir entre grupos ou indivíduos e o sistema político propriamente dito.

Assim, a proximidade das pessoas ao sistema político também depende do nível de renda e riqueza, visto que ambas incidem sobre a possibilidade de contato e, consequentemente, o escopo de intervenção de grupos e pessoas nas decisões públicas. No que tange à influência desigual exercida pelas classes sociais, o pensamento neomarxista oferece alguns insights teóricos. Nesse sentido, os conceitos de permeabilidade e seletividade servem para ilustrar a responsividade desigual do Estado perante certos grupos privilegiados economicamente.

No Brasil, por exemplo, há grande concentração de recursos em poucas instituições financeiras, em que pesa uma clara divisão entre instituições de controle estatal (Banco do 
Brasil e Caixa Econômica) e alguns bancos privados nacionais e estrangeiros (Minella, 2003).

Em 2001, "os 10 maiores bancos controlavam 72,14\% dos ativos totais de todo sistema financeiro, 65,47\% dos títulos e valores mobiliários e 73,96\% das operações de crédito e arrendamento mercantil". (p. 251). Por outro lado, observa-se um aumento na participação de bancos estrangeiros, cujo controle sobre ativos cresceu de 9,64\% (1989) para 33,1\% (2000). Cabe destacar que, entre os 20 maiores bancos, 12 são estrangeiros (Minella, 2003).

Assim, o conceito de seletividade, como exposto por Offe (1984 [1972]), aparece aqui no domínio das instituições financeiras nas decisões políticas, visto que o governo se torna dependente dessas instituições devido à necessidade de capital, tanto em termos de fluxo quanto de financiamento interno. Como afirma Minella (2003: 252), "a retirada de capital pode ser um instrumento para interferir no funcionamento de uma empresa, afetar a economia como um todo e forçar a adoção de determinadas medidas macroeconômicas".

Considerando a alta concentração de recursos em poucas instituições, pode-se inferir que o Estado seja mais suscetível a essas instituições. De um lado, a dependência estatal em relação a essas instituições financeiras deriva diretamente da concentração de recursos e, portanto, da desigualdade econômica presente no sistema financeiro.

Do outro, a dependência causa certo grau de desigualdade política, visto que tais instituições detêm oportunidades maiores de influência política em detrimento de outros grupos, incluindo até mesmo outros segmentos empresariais. Dessa forma, um tipo determinado de desigualdade econômica - no caso, referente principalmente à concentração de riqueza - implica em desigualdade política.

A influência política pode ocorrer de forma ainda mais direta, seja por meio do financiamento de campanhas ou da participação de empresários ou representantes em órgãos estratégicos de decisão (Minella, 2003), o que é compatível com o conceito de permeabilidade oferecido por Poulantzas.

Assim, as noções de permeabilidade, seletividade e dependência estrutural são úteis para ilustrar o acesso diferenciado de certos grupos econômicos ao Estado. Entretanto, enquanto Offe (1984 [1972]) e Poulantzas (2000 [1978]) focam respectivamente na dependência estrutural do Estado capitalista devido ao investimento e na composição das 
burocracias, há outras formas de contato direto com o sistema político que também dependem do provento de certos recursos econômicos, como o financiamento de campanhas e a atuação de grupos de interesse. É preciso, portanto, alargar esses conceitos de modo a abranger outras formas características de acesso às decisões públicas.

Essas formas são retratadas a seguir:

\subsubsection{Financiamento de campanhas e ocupação de cargos eletivos}

Um tema bastante discutido em termos de interação entre economia e política é o financiamento de campanhas eleitorais. No Brasil, prepondera um sistema parcialmente misto, pois há a possibilidade da utilização de recursos públicos advindos do fundo partidário e de recursos privados provenientes de doações. Tanto renda quanto riqueza podem estar relacionadas à desigualdade inerente ao sistema brasileiro, uma vez que são permitidas doações de pessoas físicas e jurídicas. Todavia o papel da riqueza é mais enfatizado pela literatura, devido ao predomínio de empresas nas doações a campanhas políticas.

No caso do fundo partidário, a distribuição dos recursos obedece à proporcionalidade dos votos obtidos pelos partidos para a Câmara dos Deputados na última eleição (Lei 9.096 de 1995, Art. 41). ${ }^{44}$. Essa regra implica em uma distribuição que ocorre de acordo com o sucesso eleitoral passado. Dessa forma, partidos menores tendem a encontrar mais dificuldades, enquanto a atual proporção é mantida, comprometendo uma mudança política (Speck, 2010).

As críticas recaem em sua maioria, porém, na questão específica do financiamento privado das campanhas. Nesse sentido, são destacados dois riscos principais inerentes às doações privadas: o primeiro refere-se ao desequilíbrio da campanha, em que os candidatos que detém mais recursos possuem mais chances de ser eleitos; o segundo está relacionado ao comprometimento da integridade dos políticos, visto que eles passam a responder mais aos financiadores que aos demais eleitores (Speck, 2010; Sztutman \& Aldrigui, 2012).

Trata-se, portanto, da geração de dois tipos de desigualdade política fundamentados na desigualdade econômica: desigualdade na capacidade dos candidatos em relação a arcar

\footnotetext{
${ }^{44} \mathrm{Na}$ verdade, $95 \%$ dos recursos do fundo obedecem a essa proporção, enquanto os 5\% restantes é distribuído a todos os partidos devidamente registrados (Lei 9.096 de 1995, Art. 41-A, na redação dada pela Lei 12.875 de 2013).
} 
com custos da campanha e desigualdade entre eleitores no que concerne à responsividade dos candidatos eleitos.

A primeira - desigualdade dos candidatos - implica na discrepância entre possibilidades de vencer uma eleição devido à concentração de recursos materiais, o que gera maiores oportunidades de acesso direto ao sistema político por parte daqueles que detém esses recursos e podem arcar com os custos de uma campanha política. Já o segundo tipo - desigualdade entre eleitores - advém do financiamento privado, o qual corrobora para capacidades desiguais de influência política, uma vez que presumidamente os políticos atenderiam mais prontamente às demandas daqueles que contribuíram financeiramente para as campanhas.

Assim, tanto candidatos quanto cidadãos se tornam desiguais, transmutando a desigualdade econômica (fruto do acesso diferenciado a recursos) em desigualdade política que pesa sobre o acesso direto às decisões públicas. Nesse contexto, o financiamento atua como "moeda de troca" ou fator de barganha política, em que o capital econômico se converte em recurso político. Dessa forma, os financiadores cederiam recursos econômicos em troca de alguns benefícios no alcance das instituições políticas.

No que tange aos supostos benefícios recebidos pelos financiadores, destacam-se no contexto brasileiro, ao menos, quatro formas com as quais pessoas jurídicas podem obter determinados privilégios:

i. Contratos públicos: os contratos públicos referem-se às obras realizadas pelo governo, que pode se utilizar de empresas privadas pela execução. Nesse contexto, as empresas se beneficiariam com a remuneração proveniente desses contratos;

ii. Investimento do Banco Nacional de Desenvolvimento Econômico e Social (BNDES): o financiamento por meio do BNDES pode ser um dos canais de trocas de favores. Nesse caso, empresas conseguiriam financiamento do Banco em troca do apoio financeiro às campanhas. Entretanto, é importante ressalvar que tal favor pode ser indireto, visto que o investimento do BNDES pode estar inserido em um contexto de contrato público. Nessa situação, a empresa seria beneficiada com o contrato e indiretamente por meio do BNDES, responsável pelo financiamento da obra (ver Sztutman \& Aldrigui, 2012); 
iii. Preço das ações: as empresas também podem se beneficiar por meio do nível de investimento, visto que os preços das ações costumam subir quando elas apoiam candidatos com mais expectativas de ser eleitos (ver Sztutman \& Aldrigui, 2012).

iv. Aprovação de políticas específicas: considerando que campanhas eleitorais geralmente requerem o dispêndio de muitos recursos e que grande parte deles pode ser fornecida por pessoas jurídicas, é razoável pressupor o desenvolvimento de certa relação de dependência entre os financiadores e os eleitos. A forma mais óbvia pela qual pode ocorrer uma troca de favores é o direcionamento sobre políticas específicas. Uma vez que deputados, senadores e detentores de cargos eletivos no poder executivo agem diretamente na construção da agenda e na formulação de políticas, é plausível supor que pode ocorrer certa pressão por parte dos financiadores em torno de decisões determinadas que sejam favoráveis aos seus interesses. Essas decisões podem incluir, por exemplo, a redução de impostos para setores específicos ou a flexibilização da legislação trabalhista em favorecimento aos empregadores.

A tabela 12 mostra dados relativos ao financiamento da campanha de 2012 pelas 20 maiores empresas doadoras. As informações contidas abrangem a empresa doadora, o montante recebido em contratos públicos a nível federal e o valor total doado na campanha a nível municipal, assim como o sujeito-alvo das doações, isso é, "para quem" a empresa direciona a doação em termos de partido, candidato ou comitê.

Tabela 12 - Financiamento de campanhas e contratos públicos (2012)

\begin{tabular}{c|c|c|c|c|c}
\hline DOADOR & $\begin{array}{c}\text { No. } \\
\text { Doações }\end{array}$ & $\begin{array}{c}\text { Valor total } \\
\text { doado }\end{array}$ & $\begin{array}{c}\text { Sujeito-alvo da } \\
\text { doação }\end{array}$ & $\begin{array}{c}\text { Ranking de } \\
\text { mais } \\
\text { contratadas }\end{array}$ & $\begin{array}{c}\text { Valor recebido em } \\
\text { contratos } \\
\text { (Governo Federal) }\end{array}$ \\
\hline $\begin{array}{c}\text { 1. CONSTRUTORA ANDRADE } \\
\text { GUTIERREZ SA }\end{array}$ & 133 & $81.165 .800,00$ & $\begin{array}{c}\text { Partidos e } \\
\text { candidatos }\end{array}$ & - & $99.228 .136,19$ \\
\hline $\begin{array}{c}\text { 2. CONSTRUTORA QUEIROZ GALVAO } \\
\text { SA }\end{array}$ & 107 & $52.135 .000,00$ & Partidos & 60 & $518.932 .189,87$ \\
\hline $\begin{array}{c}\text { 3. CONSTRUTORA OAS S.A. } \\
\begin{array}{c}\text { 4. CONSTRUCOES E COMERCIO } \\
\text { CAMARGO CORREA S/A }\end{array}\end{array}$ & 153 & $44.090 .000,00$ & $\begin{array}{c}\text { Partidos, candidatos } \\
\text { e comitês }\end{array}$ & - & 0,00 \\
\hline
\end{tabular}




\begin{tabular}{|c|c|c|c|c|c|}
\hline 5. VALE FERTILIZANTES S.A. & 29 & $30.470 .000,00$ & Partidos & - & 0,00 \\
\hline 6. E.V. TEIXEIRA & 1 & $28.500 .009,08$ & $\begin{array}{c}\text { Candidato (apenas } \\
\text { um) }\end{array}$ & - & 0,00 \\
\hline 7. BANCO BMG SA & 207 & $24.008 .000,00$ & $\begin{array}{l}\text { Partidos, candidatos } \\
\text { e comitês }\end{array}$ & - & 0,00 \\
\hline $\begin{array}{l}\text { 8. PRAIAMAR INDUSTRIA COMERCIO } \\
\text { \& DISTRIBUICAO LTDA }\end{array}$ & 49 & $22.410 .000,00$ & $\begin{array}{l}\text { Partidos e } \\
\text { candidatos }\end{array}$ & & 0,00 \\
\hline 9. JBS S/A & 25 & $20.210 .000,00$ & Partidos e comitês & & $76.539,66$ \\
\hline $\begin{array}{l}\text { 10. CONSTRUTORA NORBERTO } \\
\text { ODEBRECHT S A }\end{array}$ & 23 & $19.450 .000,00$ & $\begin{array}{l}\text { Partidos e } \\
\text { candidatos }\end{array}$ & 1 은 & 1.135.742.556,26 \\
\hline 11. U T C ENGENHARIA S/A & 227 & $17.973 .149,00$ & $\begin{array}{c}\text { Partidos, candidatos } \\
\text { e comitês }\end{array}$ & - & 0,00 \\
\hline $\begin{array}{l}\text { 12. CARIOCA CHRISTIANI NIELSEN } \\
\text { ENGENHARIA S A }\end{array}$ & 53 & $15.282 .000,00$ & $\begin{array}{c}\text { Partidos, candidatos } \\
\text { e comitês }\end{array}$ & - & $20.397 .756,62$ \\
\hline 13. GALVAO ENGENHARIA S/A & 50 & $11.697 .000,08$ & $\begin{array}{c}\text { Partidos, candidatos } \\
\text { e comitês }\end{array}$ & - & $88.144 .707,31$ \\
\hline 14. CONTAX S.A. & 25 & $11.495 .000,00$ & $\begin{array}{l}\text { Partidos e } \\
\text { candidatos }\end{array}$ & - & 0,00 \\
\hline 15. BANCO ALVORADA S.A. & 38 & $10.250 .000,02$ & Partidos e comitês & - & 0,00 \\
\hline 16. ITAU UNIBANCO S.A. & 271 & $10.198 .222,50$ & $\begin{array}{l}\text { Candidatos de } \\
\text { partidos variados }\end{array}$ & - & $162.514 .934,18$ \\
\hline 17. BRASKEM S/A & 124 & $9.800 .000,00$ & $\begin{array}{c}\text { Partidos, candidatos } \\
\text { e comitês }\end{array}$ & - & $49.363 .083,00$ \\
\hline $\begin{array}{l}\text { 18. COIMBRA IMPORTACAO E } \\
\text { EXPORTACAO LTDA }\end{array}$ & 33 & $9.260 .187,23$ & $\begin{array}{l}\text { Candidatos e } \\
\text { comitês (PPS) }\end{array}$ & - & $150.516,73$ \\
\hline 19. TEMPO SERVICOS LTDA. & 37 & $8.880 .000,00$ & Partidos e comitês & - & 0,00 \\
\hline 20. BANCO BANKPAR S.A. & 45 & $8.740 .000,00$ & Partidos & - & 0,00 \\
\hline
\end{tabular}

Fonte: elaboração da autora, a partir de dados do TSE e Portal da Transparência recolhidos por meio do aplicativo Politicaaberta.org ${ }^{45}$.

Nota-se que há uma predominância dos partidos no recebimento de doações. Nesse sentido, não há um único partido que se destaque, visto que as empresas costumam doar para partidos distintos, inclusive em termos ideológicos. A Construtora Andrade Gutierrez, por exemplo, fez doações, em 2012, ao Partido dos Trabalhadores (PT), ao Partido da

\footnotetext{
${ }^{45}$ Vale ressaltar que é natural que dados sobre financiamento de campanha apresentem limitações que impedem conclusões definitivas sobre a temática, uma vez que os únicos dados disponíveis são os de órgãos oficiais (os quais não podem garantir a veracidade das informações declaradas pelos partidos).
} 
Social Democracia Brasileira (PSDB) e ao Partido Social Democrático (PSD), entre outros (Politica Aberta, s/d). Mesmo quando a doação concentra-se em alguns candidatos, eles geralmente pertencem a partidos variados.

A hipótese é que as empresas doariam para mais partidos, mesmo que distantes no espectro ideológico, devido à maior probabilidade de algum deles se eleger. Assim, o que nortearia o direcionamento das doações seria a percepção de adquirir vantagens após as eleições em vez do alinhamento ideológico. No entanto, nem todas as doadoras receberam benefícios em termos de contratos públicos. A tabela indica que algumas chegaram a receber nenhum valor em contratos, o que pode dificultar a exposição de alguma correlação.

Todavia, é preciso esclarecer que os dados referentes às doações tratam das eleições municipais, enquanto os dados relativos aos contratos referem-se ao âmbito federal. Assim, a aparente falta de correlação pode aparecer devido à ausência de sincronia entre os dados. Seria necessário, portanto, analisar dados sobre os contratos a nível municipal e as doações em eleições federais e compará-los respectivamente com as doações municipais e os contratos a nível federal.

Nesse sentido, ainda vale ressaltar que a maior parte das empresas que participou do financiamento das campanhas e foi beneficiada por meio de contratos recebeu um valor superior ao doado. Comparando o valor total doado e o valor recebido em contratos, constata-se que essa diferença pode chegar a uma razão de 58 vezes o valor, como demonstra os valores relativos à Odebrecht. Isso implica na observação de que o financiamento de campanhas pode atuar como um investimento de elevado retorno, tendo em vista a diferença entre o valor recebido e o valor doado.

Além disso, há outros tipos de benefícios que podem ser recebidos pelos doadores de campanha, tais como o investimento por meio do BNDES e a influência sobre políticas públicas e legislação, incluindo temáticas como isenções fiscais, leis trabalhistas e barreiras alfandegárias. Assim, embora não seja possível extrair uma correlação entre financiamento e contratos meramente pela tabela exposta, é possível fazer algumas especulações sobre o relacionamento entre empresas e governo, principalmente no que tange aos benefícios recebidos pelas grandes empresas.

Os recursos advindos do BNDES se constituem possivelmente em um meio com a qual os financiadores de campanhas podem se beneficiar em uma provável troca de 
favores. A tabela 13 mostra os desembolsos feitos em relação às empresas exportadoras por ano, no período de 2010 a 2012, para as trinta empresas que desembolsaram o maior volume de recursos. Trata-se de uma lista de empresas beneficiadas por recursos do BNDES (em US\$, na tabela) para exportações.

Tabela 13 - Desembolsos pós-embarque por empresa exportadora (2010-2013)

\begin{tabular}{|c|c|c|c|c|c|}
\hline $\begin{array}{c}\text { EMPRESA BENEFICIADA / RECURSOS } \\
\text { OBTIDOS (EM US\$) }\end{array}$ & 2010 & 2011 & 2012 & 2013 & $\begin{array}{l}\text { Total no } \\
\text { período }\end{array}$ \\
\hline EMBRAER S/A & 1.312 .954 .549 & 1.059.026.619 & 627.917 .700 & 1.072 .603 .926 & 4.072.502.793 \\
\hline CONSTRUTORA NORBERTO ODEBRECHT S/A & 683.570 .697 & 1.078.210.626 & 1.186 .118 .171 & 998.235 .182 & 3.946.134.676 \\
\hline CONSTRUTORA ANDRADE GUTIERREZ S/A & 69.615 .623 & 292.185 .555 & 46.353 .638 & 228.510 .268 & 636.665 .084 \\
\hline IVECO LATIN AMERICA LTDA & 76.668 .576 & 82.797 .200 & - & - & 159.465 .776 \\
\hline CONFAB INDUSTRIAL S/A & 60.266 .787 & 90.658 .503 & - & - & 150.925 .289 \\
\hline MERCEDES-BENZ DO BRASIL LTDA. & 102.413 .850 & 35.779 .980 & - & - & 138.193 .830 \\
\hline CONSTRUTORA QUEIROZ GALVAO S/A & - & - & 117.446 .891 & 8.448 .330 & 125.895 .221 \\
\hline $\begin{array}{l}\text { CONSTRUCOES E COMERCIO CAMARGO } \\
\text { CORREA S/A }\end{array}$ & 21.217.056 & 12.524 .728 & 68.208 .615 & 22.178 .809 & 124.129 .208 \\
\hline CONSTRUTORA OAS LTDA & - & - & 16.548 .361 & 64.957 .828 & 81.506 .189 \\
\hline WEG EQUIPAMENTOS ELETRICOS S/A & - & 1.328 .090 & 12.112.216 & 39.833 .590 & 53.273 .896 \\
\hline SCANIA LATIN AMERICA LTDA & 40.103.117 & 8.663 .165 & 1.231 .807 & 2.481 .035 & 52.479 .125 \\
\hline CNH LATIN AMERICA LTDA & 11.207.176 & 953.535 & 25.696 .395 & 7.813 .150 & 45.670 .256 \\
\hline SERMATEC INDUSTRIA E MONTAGENS LTDA & - & 5.312 .554 & 10.044 .249 & - & 15.356 .803 \\
\hline $\begin{array}{l}\text { MELLO JUNIOR - EMPREENDIMENTOS E } \\
\text { PARTICIPACOES LTDA. }\end{array}$ & - & 4.041 .254 & 6.504 .501 & 4.460 .995 & 15.006 .750 \\
\hline JOHN DEERE BRASIL LTDA. & - & 2.412 .857 & 2.209 .392 & 9.087 .085 & 13.709 .334 \\
\hline TPRO ENGENHARIA S.A. & - & 3.026 .886 & 2.973 .924 & 6.830 .114 & 12.830 .924 \\
\hline METSO BRASIL INDUSTRIA E COMERCIO LTDA & - & - & 9.819 .622 & - & 9.819 .622 \\
\hline $\begin{array}{l}\text { ARMCO STACO S/A INDUSTRIA } \\
\text { METALURGICA }\end{array}$ & - & 4.632 .441 & 4.066 .744 & - & 8.699 .184 \\
\hline A L HECHER MADEIRAS & 577.550 & 4.161 .111 & 1.249 .695 & 2.595 .280 & 8.583 .636 \\
\hline $\begin{array}{l}\text { BUREAU DE PROJETOS E CONSULTORIA } \\
\text { LTDA. }\end{array}$ & - & - & - & 7.645 .261 & 7.645 .261 \\
\hline $\begin{array}{l}\text { MAUBERTEC EMPREENDIMENTOS E } \\
\text { CONSTRUCOES LTDA }\end{array}$ & 2.424 .067 & 2.260 .914 & 579.508 & 379.872 & 5.644 .361 \\
\hline F. M. COEMPAR COMERCIAL LTDA & - & - & 5.607 .729 & - & 5.607 .729 \\
\hline CONTRACTA ENGENHARIA LTDA & - & - & - & 4.640 .318 & 4.640 .318 \\
\hline MOTOROLA INDUSTRIAL LTDA & 4.498 .183 & - & - & - & 4.498 .183 \\
\hline INDUSTRIAS ROMI S/A & 584.368 & 1.086 .284 & 1.817 .174 & 599.434 & 4.087.259 \\
\hline COMERCIAL SURIMPEX LTDA. & - & - & 1.311 .484 & 2.659 .379 & 3.970 .863 \\
\hline KEPLER WEBER S/A & - & - & 3.909 .114 & - & 3.909 .114 \\
\hline FABRIMA MAQUINAS AUTOMATICAS LTDA & - & - & 3.891 .275 & - & 3.891 .275 \\
\hline
\end{tabular}

Fonte: elaboração da autora, a partir de dados do BNDES.

Por meio da tabela 13, verifica-se que algumas das empresas que recebem benefícios coincidem com as doadoras de campanhas, o que poderia ser uma evidência a 
mais acerca da existência de algum tipo de relação, embora não implique necessariamente em causalidade tendo em vista a falta de um teste de hipótese mais preciso. Vale lembrar também que essa se constitui em apenas mais uma modalidade de auxílio financeiro por parte do BNDES, que fornece outros tipos de benefícios aos quais as empresas poderiam ter contato.

Outra ressalva às tabelas apresentadas é que algumas empresas podem pertencer a um mesmo grupo econômico, o que salienta a importância de se utilizar o grupo como análise em vez das empresas. Análises que consideram apenas as empresas em detrimento dos grupos econômicos podem apresentar distorções em relação à predominância desses grupos, visto que podem ocultar a concentração de recursos. ${ }^{46}$ Como mostram Sztutman e Aldrighi (2012), até o valor doado por unidade é maior quando são considerados os grupos econômicos no lugar das empresas.

Dessa forma, as evidências apontam para um ciclo vicioso, no qual a concentração inicial de recursos econômicos corrobora para a expansão dessa concentração por meio da extração de benefícios no sistema político. A desigualdade política, nesse caso, é consequência da troca de favores entre empresas ou grupos econômicos e políticos profissionais, em que determinados grupos possuem maior acesso às decisões públicas como recompensa pelo apoio financeiro dado.

Sobretudo, a temática do financiamento de campanhas destaca um tipo importante de desigualdade política inerente à democracia representativa: a disparidade na competição por cargos eletivos. Primeiramente, a própria existência de eleições já traz uma diferença nítida entre eleitos e eleitores, em que os primeiros possuem muito mais potencial em impactos diretos nas decisões públicas. Considerando os poucos mecanismos de controle da atuação dos representantes pelo eleitorado ou a dificuldade de acesso a eles pela maioria da população, a diferença entre eleitos e eleitores desemboca em elevado grau de desigualdade política.

Em segundo lugar, é preciso levar em consideração o próprio funcionamento do mecanismo eleitoral. Tendo em vista a dinâmica interna das eleições, cujo objetivo de candidatos é arrecadar o maior número de votos, é razoável pensar que não se trata de uma

\footnotetext{
${ }^{46}$ Sztutman e Aldrighi (2012) destacam, contudo, que a utilização de grupos econômicos como unidade de análise não está livre de problemas, em que se tem como exemplo a dificuldade de acesso aos dados em comparação com a análise das empresas de capital aberto.
} 
competição equitativa, visto que os competidores não possuem o mesmo ponto de partida. O problema aqui não é a chance de vitória em si, visto que ela dificilmente será igual mesmo em uma situação de equidade econômica, mas a discrepância de recursos materiais de campanha e a origem desses recursos, a qual implica em uma diferença no relacionamento entre políticos e diferentes grupos socioeconômicos.

A questão central, portanto, refere-se aos fatores que determinam essas chances. Nesse sentido, a quantidade de recursos econômicos dos quais dispõem os candidatos é um dos fatores centrais, visto que as campanhas implicam em inúmeros gastos. Assim, a desigualdade na concentração de recursos - advindos tanto dos rendimentos quanto da concentração de capital - gera desigualdade política, pois candidatos específicos possuem mais chances de vencer as eleições e, consequentemente, ao assumir o poder terão mais acesso às decisões que os demais membros da sociedade.

Além de variáveis como gênero, profissão e origem social, outro possível fator que pode afetar a possibilidade de ganhar uma eleição é o nível educacional dos candidatos, que pode influenciar tanto diretamente em termos de estima quanto indiretamente por meio da aquisição de certas capacidades necessárias ao convencimento. Dessa forma, cabe indagar qual o impacto da renda e da riqueza sobre esses fatores. Renda possui amplo impacto sobre nível educacional, enquanto a concentração de riqueza pode contribuir diretamente no financiamento das campanhas e na formação de redes de apoiadores.

Nesse sentido, os estudos sobre carreiras políticas trazem grandes contribuições à formulação e ao teste de hipóteses sobre o sucesso político, pois permitem a análise do perfil dos candidatos eleitos, destacando consequentemente fatores em comum que estariam relacionados à possibilidade de sucesso na eleição. Sobretudo, estudos de recrutamento político estão relacionados à problemática dos filtros, os quais podem ser definidos como mecanismos "que operam no processo de seleção de grupos sociais a posições de elite" (Codato e Costa, 2011: 6). Tais mecanismos podem ser culturais, institucionais ou profissionais e remetem à estrutura de oportunidades da participação política (Codato e Costa, 2011).

Assim, a temática do recrutamento político e da ascensão à política traz à tona a própria discussão acerca da qualidade de democracia, uma vez que a capacidade de indivíduos da massa ascenderem a posições de elites permite demonstrar o quanto o campo político é mais ou menos permeável aos grupos sociais de forma geral. Todavia, isso não 
implica necessariamente em menor distanciamento entre elite e massa, se a última dispõe de poucos instrumentos de controle e intervenção no sistema político.

Dessa forma, estuda-se a existência de obstáculos de acesso à política. No caso dos estudos sobre o poder legislativo brasileiro, entre os fatores que podem se constituir em barreiras à ocupação de cargos eletivos estão o montante de recursos arrecadados nas campanhas e a ocupação profissional dos candidatos eleitos.

No que tange ao financiamento, alguns trabalhos demonstram correlação positiva entre recursos dos candidatos e desempenho eleitoral dos partidos, como a análise de Cervi (2010) sobre os candidatos às prefeituras das capitais brasileiras em 2008. O autor demonstra que o total de recursos é um fator relevante no desempenho eleitoral, principalmente no que tange às doações das pessoas jurídicas ${ }^{47}$.

De forma geral, presume-se que as campanhas que recebem mais votos e possuem mais chances de vitórias são aquelas que contam com maior número de recursos. Assim, existem evidências que corroboram para os impactos da renda e da riqueza na desigualdade política expressa pelas diferentes chances de sucesso eleitoral decorrentes da disposição dos recursos econômicos.

Já a ocupação profissional afetaria a ocupação de cargos eletivos por estar relacionada ao tempo livre do qual dispõem os indivíduos, além de propiciar a aquisição de recursos materiais. Renda pode estar relacionada a maiores chances de inserção na política, pois permite que indivíduos arquem com certos custos, enquanto riqueza pode estar relacionada à formação de redes de contato, necessárias a qualquer articulação política.

No que tange ao perfil profissional dos parlamentares, grande parte dos estudos concentra-se na temática acerca da relação entre empresariado e política. De forma geral, a composição do parlamento brasileiro contou com forte presença do empresariado desde o Império, passando por várias fases da política brasileira e alcançando uma proporção de 38\% dos eleitos para a Câmara dos Deputados em 1990 (Costa, Costa e Nunes, 2014).

\footnotetext{
${ }^{47}$ A análise demonstrou uma correlação positiva de 0.281 entre total de recursos e desempenho eleitoral, a um nível de significância de 0.05. Estatisticamente, isso significa que a explicação da variação do desempenho eleitoral pelo total de recursos está em torno de $28 \%$. O parâmetro - utilizado na regressão linear para medir o impacto da variável - foi de 0.284 em nível de significância 0,000 . Tal impacto ainda é menor que o da variável que representa as doações das pessoas jurídicas, o que indica a importância exacerbada das doações feitas por empresas em detrimento das pessoas físicas.
} 
Após a vitória do PT nas eleições presidenciais de 2002, houve a percepção de que poderia ocorrer uma alteração na classe política brasileira, em que estava presente a ideia de "popularização". Isso significaria um aumento no número de deputados federais advindos das classes médias assalariadas e, em menor grau, das classes populares, ao passo que haveria uma redução de parlamentares da classe alta. De fato, verificou-se uma queda na quantidade percentual de indivíduos de perfil mais tradicionalista, enquanto aumentouse o montante de indivíduos com profissões típicas de classe média (Costa, Costa e Nunes, 2014).

No Senado, também foi verificada uma leve diminuição de algumas profissões ditas "tradicionais", principalmente no campo do Direito, que predominava de forma discrepante na 50ª legislatura (1995-1999) - como ilustrado no gráfico abaixo.

\section{Gráfico 1- Profissões dos Senadores ${ }^{48}$}

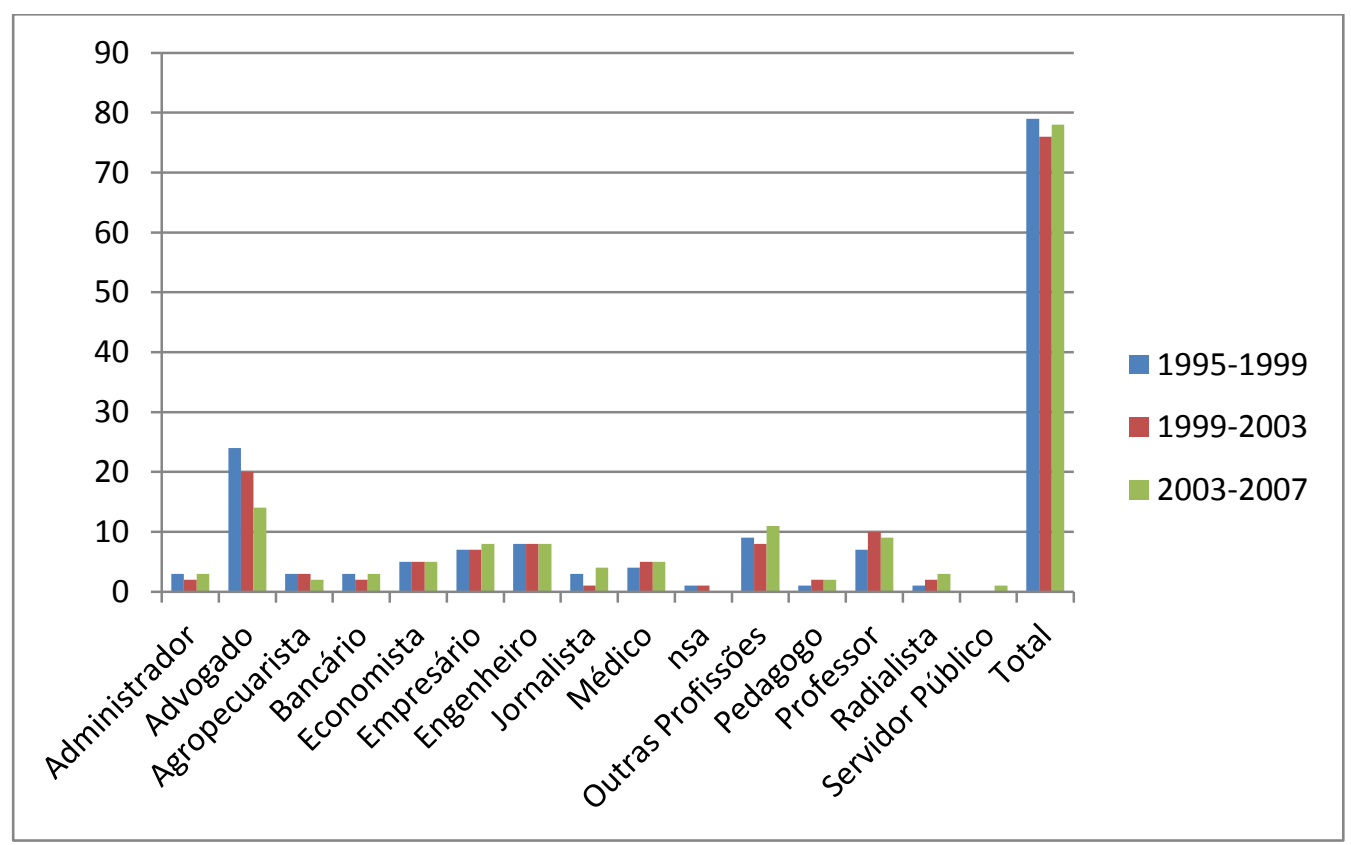

Fonte: Elaboração da autora, a partir da base de dados feita e disponibilizada por Paulo Magalhães Araújo, professor do Departamento de Ciências Sociais da Universidade Federal do Espírito Santo (UFES), em pesquisa financiada pela Fundação de Amparo à Pesquisa no Espírito Santo (FAPES).

No gráfico supracitado, nota-se que há uma diminuição dos advogados na passagem para as duas últimas legislaturas, enquanto o espectro de profissões se diversifica. Apesar

\footnotetext{
${ }^{48}$ Agradeço ao professor Paulo Magalhães Araújo por disponibilizar a base de dados e à minha colega Noëlle Silva pela ajuda com a divisão das categorias e, consequentemente, a construção dos gráficos.
} 
disso, algumas profissões tradicionais se mantiveram, como os médicos e os bancários, enquanto outras sofreram um aumento, como no caso dos empresários.

De toda forma, seria difícil atribuir essa mudança a uma espécie de "popularização". Contrariamente, provavelmente houve uma "profissionalização" da política: pesquisas mais recentes têm mostrado que grande parte dos candidatos eleitos já eram membros do poder legislativo (Codato e Costa, 2011). Nesse sentido, a experiência prévia parece ser uma variável importante, embora existam certos atalhos, como a exposição dos candidatos à mídia (ver Miguel, 2003).

A influência direta do poder econômico é mais difícil de analisar, uma vez que a origem das informações nesse tipo de estudo remete geralmente aos próprios parlamentares, apresentando lacunas ou dados incompletos ${ }^{49}$. Mesmo com esses problemas, é possível construir certas hipóteses acerca de possíveis impactos causados por renda e riqueza na ocupação de cargos eletivos. Renda está relacionada a outras variáveis, que provavelmente afetam a capacidade de inserção no sistema político. Nível de instrução é uma delas, como demonstrado pelo gráfico seguinte.

Gráfico 2 - Nível de instrução dos Senadores ${ }^{50}$

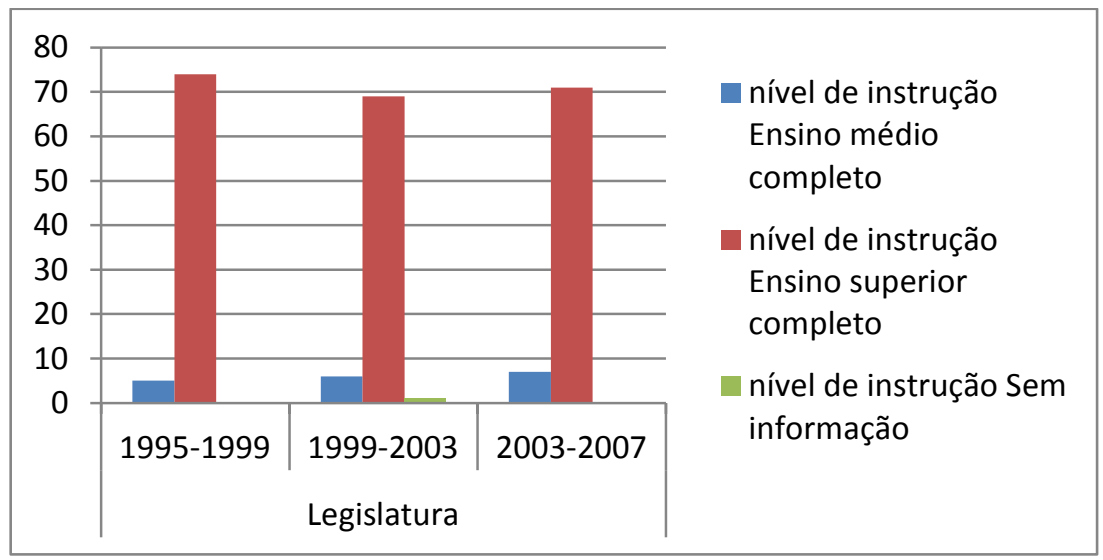

Fonte: Elaboração da autora, a partir da base de dados feita e disponibilizada por Paulo Magalhães Araújo, professor do Departamento de Ciências Sociais da Universidade Federal do Espírito Santo (UFES), em pesquisa financiada pela Fundação de Amparo à Pesquisa no Espírito Santo (FAPES).

De acordo com o gráfico apresentado, há uma predominância clara do nível superior no nível de instrução dos senadores, em todas as três legislaturas analisadas.

\footnotetext{
${ }^{49}$ Miguel (2003) apresenta essa mesma ressalva ao introduzir uma tabela com as possíveis fontes de capital político, em que os índices do poder econômico encontram-se mais baixos do que o esperado.

${ }^{50}$ Os números no eixo representam a quantidade de parlamentares em termos absolutos.
} 
Rendimentos recebidos pelos indivíduos afetam as oportunidades de acesso à educação, as quais por sua vez condicionam as possibilidades de participação política, seja devido à aquisição de habilidades legitimadas como "necessárias" à atividade política seja pela apreensão de certos conteúdos. Riqueza, por sua vez, incide sobre a formação de redes de contato (networking) e, consequentemente, na capacidade de articulação.

Dessa forma, a distribuição de renda e riqueza pode afetar a igualdade política em termos da ocupação de cargos eletivos, mesmo que de forma indireta. Assim, alguns indivíduos com determinadas características possuem maior chance de sucesso eleitoral e maior acesso às decisões públicas, o que compromete o princípio da igualdade política. Além disso, como “experiência prévia” é importante para o sucesso em alguns cargos eletivos, é provável que a influência de fatores como renda e riqueza seja reforçada, uma vez que esses aspectos incidem também nas possibilidades de experiência prévia dos candidatos.

Pesquisas nessa área precisam ser encorajadas. Todavia, a realização de testes empíricos mais precisos encontram certas dificuldades, principalmente relacionada à coleta dos dados. No que tange ao financiamento de campanhas, seria necessário mapear todas as possibilidades de benefícios recebidos pelas financiadoras e agrupá-los em uma única variável dependente para conseguir verificar alguma correlação entre doação e retorno. Já no que concerne à ocupação de cargos eletivos, seria interessante obter dados mais específicos sobre a origem econômica dos parlamentares, como a profissão e o nível de instrução dos pais e os rendimentos recebidos na ocupação anterior, além do patrimônio declarado.

\subsubsection{Burocracia e grupos de pressão ${ }^{51}$}

A existência de uma vasta burocracia foi consequência da crescente complexidade das relações políticas e da centralização do poder, o que causou a necessidade de atuação do Estado em diversas áreas, principalmente no âmbito econômico. Entretanto, malgrado o papel cada vez mais atuante da burocracia, ela demorou a ganhar proeminência nos estudos políticos. Parte dessa omissão pode ter ocorrido devido à associação da burocracia a um

\footnotetext{
51 Teoricamente, grupos de pressão distinguem-se de grupos de interesse devido à pressão política que exercem no sistema político. Já os lobbies referem-se os "grupos de pressão que instrumentalizam recursos de poder em busca de influência" (Santos, 2007: 83). O lobby também pode ser visto como método utilizado pelos grupos de pressão, isso é, uma transmissão de mensagem do grupo aos tomadores de decisão por meio de representantes que fazem contato direto com parlamentares ou membros do governo (Santos, 2007). Nesse trabalho, os termos serão utilizados como sinônimos.
} 
papel exclusivamente administrativo, "segundo o qual a interferência política da burocracia dar-se-ia, quando muito, no sentido da criação de 'barreiras administrativas' ou no sentido de uma crescente atomização do quadro institucional” (Bayer, 1975: 83).

Bayer (1975) destaca que essa restrição não é sequer justificada teoricamente, uma vez que desvincula o estudo da burocracia à problemática mais ampla da dominação política. De forma semelhante, Loureiro, Olivieri e Martes (2010) destacam o estudo de Aberbach, Putnam e Rockman (1981), os quais indicam que a burocracia pública não só participa dos processos de decisão do Executivo como está sujeita ao controle exercido pelo Legislativo.

Considerando que a burocracia é um instrumento de dominação e propicia maior contato com o poder político no exercício de suas funções, torna-se imperativo seu estudo no que tange ao seu relacionamento com as diversas camadas que compõem a sociedade. Nesse sentido, Poulantzas (2000 [1978]) enfatizava a "infiltração" das classes capitalistas no Estado por meio da ocupação de cargos na burocracia e do conceito de permeabilidade.

Segundo o autor, o Estado não seria um agente monolítico, mas um aparato marcado pelas contradições de classe. Mesmo que composto por várias frações de classe, o Estado estaria sujeito a uma hegemonia de uma classe ou fração, o que desemboca em uma política a favor desse respectivo segmento, como já explicado no Capítulo 2 desse trabalho. A tradição marxista no estudo da burocracia, porém, tende à conclusão de que o Estado teria certa autonomia devido à multiplicidade das forças políticas e à heterogeneidade da burguesia, que seria incapaz de exercer a hegemonia (Loureiro, Olivieri e Martes, 2010).

Uma segunda vertente analítica nesses estudos sobre o Brasil, por outro lado, foca no dilema entre insulamento burocrático e clientelismo. Nesse sentido, o predomínio da burocracia decorreria da incapacidade dos partidos políticos no que se refere a suas atribuições de governo. Com a centralização e consequente crescimento do aparato burocrático, teria restado aos partidos apenas a defesa de interesses particularistas ou de clientelas específicas (Loureiro, Olivieri e Martes, 2010) ${ }^{52}$.

\footnotetext{
52 Essa vertente divide-se, ainda, em dois subgrupos: um que defende o insulamento burocrático como solução ao clientelismo e outro que discute os problemas derivados do insulamento. Vale destacar também que tais estudos concentram-se na área de políticas econômicas. Ver Loureiro, Olivieri e Martes, 2010.
} 
As duas vertentes convergem no reconhecimento da burocracia como ator político central, mas divergem em relação à fonte de poder do aparato burocrático: no caso da tradição marxista, seriam os interesses socioeconômicos representados, ao passo que na segunda vertente o poder atribuído à burocracia seria consequência de uma decisão estratégica do Poder Executivo (Loureiro, Olivieri e Martes, 2010). Nota-se, portanto, que tais perspectivas estão centradas nas causas do poder em vez de analisar suas consequências.

Considerando a preponderância da burocracia como agente decisório, é fundamental indagar quais os resultados práticos para o regime democrático. Se a burocracia possui um peso fundamental nas decisões públicas, cabe analisar qual o contato desse segmento com os demais estratos sociais. Tal análise corrobora para uma reflexão acerca das relações entre o Estado e a sociedade civil. Tendo em mente o contexto brasileiro, surgem várias indagações: o Estado brasileiro seria mais permeável a alguma classe ou grupo específico? Se sim, qual seria essa classe? Como renda e riqueza contribuiriam para maior permeabilidade estatal a determinados grupos?

Olhar para a burocracia e como ela se relaciona com a sociedade civil pode ajudar a responder algumas dessas perguntas. No caso do Brasil, grande parte dos cargos da Administração Pública é ocupada por servidores de carreira, selecionados por meio de concurso público. Todavia, por mais neutra que pode parecer essa seleção devido a uma pretensa falta de discriminação em termos de raça, gênero ou classe, ela não está livre de filtros sociais e econômicos.

Dessa forma, tendo em vista a alta competividade na busca por empregos públicos, é razoável supor que renda e riqueza incidam sobre as chances que os indivíduos possuem de conquistar um espaço no serviço público e, consequentemente, ter mais acesso à informação e ao processo decisório.

Pessoas com maiores rendimentos provavelmente possuem mais acesso a materiais didáticos ou dispõem de mais tempo livre para ser dedicado aos estudos, o que pode corroborar para uma maior chance de aprovação em concursos. De forma semelhante, gênero e raça podem afetar essas chances devido às diferentes oportunidades que possuem os grupos que se enquadram nessas características. Parte significativa das mulheres, por exemplo, ainda é socialmente pressionada a manter-se concentrada majoritariamente nas atividades domésticas, o que compromete sua entrada no mercado de trabalho. 
Vale ressaltar, ainda, que a burocracia brasileira pode contribuir até mesmo para a desigualdade econômica: não apenas os rendimentos são maiores comparativamente ao setor privado, mas dentro do próprio setor público há grandes diferenciais nos salários segundo os três poderes, os órgãos e os cargos ${ }^{53}$.

Sobretudo, o repasse monetário realizado do Estado para o setor público, beneficiando uma parcela diminuta da população, excede o montante direcionado às camadas mais amplas e mais pobres, como mostram Medeiros e Souza (2013: 145): "A concentração é tal que a soma dos pagamentos do Estado para os 5\% mais ricos da população $(38 \%)$ é maior do que a soma de todos os pagamentos feitos à grande maioria formada pelos $80 \%$ mais pobres $(32 \%)^{54 \%}$.

No que tange à desigualdade política, tendo em vista que a burocracia, de forma geral, tem mais acesso a determinadas informações ligadas ao sistema político e, no caso do alto escalão, às decisões tomadas nessas arenas, as diferentes oportunidades de entrada no serviço público já denota uma grave desigualdade política. Sobretudo, a existência de cargos comissionados e a falta de clareza em seus critérios podem contribuir para acesso diferenciado por parte de classes ou grupos específicos à Administração Pública e consequentemente ao lócus em que decisões políticas são tomadas.

Dessa forma, semelhante à ocupação de cargos políticos, torna-se necessário analisar o recrutamento dos cargos da burocracia pública. Em relação aos servidores, de forma geral, há uma predominância clara de pessoas com nível superior, mesmo em cargos que exigem apenas Ensino Médio (MP, 2014).

Essa tendência pode ocorrer em função de um dos métodos de seleção mais adotados ser o concurso público, o que poderia exigir conhecimentos mais facilmente adquiridos quando se dispõe da experiência de cursar a graduação. Nesse sentido, pessoas

\footnotetext{
${ }^{53}$ Para uma comparação entre setor público e privada, controlando pela variável "escolaridade", ver: < http://www.econ.puc-rio.br/pdf/td560.pdf $>$ Para verificar a desigualdade de rendimentos presente no serviço público, basta analisar os planos de carreiras disponibilizados em: <http://www.econ.pucrio.br/pdf/td560.pdf $>$. Isso não significa, porém, que o cerne da questão esteja meramente nos gastos com a Administração Pública. Um problema mais relevante e difícil de ser resolvido resulta da superexploração da mão de obra no Brasil.

${ }^{54}$ Isso não significa, porém, que uma diminuição nos gastos com o funcionalismo implicaria obrigatoriamente em diminuição da desigualdade, visto que ela é composta por fatores que são dependentes, como relatam os autores. Além disso, como mencionado anteriormente, a realidade do serviço público é bastante desigual em seu interior e os gastos variam segundo a prioridade atribuída a certos setores. Sobretudo, não adianta focar apenas no serviço público e esquecer outros aspectos mais centrais no debate sobre desigualdade, como a superexploração de mão de obra.
} 
com maior nível de escolaridade, e potencialmente com maior renda, teriam mais chances de entrar na burocracia pública e, consequentemente, influenciar as decisões políticas ${ }^{55}$, o que por si só já implicaria em certo grau de desigualdade política, como argumentado anteriormente.

Vale destacar, sobre esse aspecto, que não apenas a ocupação desses cargos é relevante, mas também o contato que membros da sociedade civil possuem com as pessoas que ocupam esses cargos tem impacto no acesso diferenciado às decisões públicas. Através do contato pessoal, membros de fora da Administração Pública podem adquirir informações privilegiadas ou até mesmo intervir de certa maneira no sistema político. Assim, supõe-se que renda e riqueza afetariam também a formação dessas redes, o que contribui para que algumas pessoas ou grupos tenham mais contato com o aparato estatal em detrimento de outras.

Dessa forma, não apenas a composição do aparato estatal em si é importante, mas o contato entre os ocupantes desse espaço com os grupos que se encontram fora dele. Há, portanto, uma interação entre os conceitos de seletividade e permeabilidade: enquanto determinados grupos econômicos podem ter mais acesso a postos dentro do governo, eles também possuem maiores oportunidades de pressionar em prol de uma ou outra decisão por meio do contato com a burocracia. O Estado, por outro lado, pode ter mais incentivos para atender às demandas desses grupos devido à dependência estrutural.

Analisando as tendências latino-americanas na relação entre e Estado e sociedade, Eli Diniz (1992) argumenta que os partidos teriam perdido parte da sua função identitária, transferindo as demandas para o aparato estatal sem que houvesse uma mediação de interesses. Assim,

Ao penetrarem no aparelho estatal, sob a influência de contatos informais ou através da pressão de organizações empresariais, os interesses particulares passariam à esfera pública, insinuando-se nas instâncias governamentais e dando origem à privatização de segmentos expressivos do Estado (Diniz, 1992: sem paginação).

\footnotetext{
55 É importante salientar também que nem todos os cargos no serviço público apresentam impactos nas decisões políticas, visto que alguns são predominantemente administrativos. É inegável, porém, que ao menos os cargos do alto escalão podem afetar substancialmente o rumo das políticas de governo. Não à toa o conceito de burocracia geralmente adotado remete a esses postos.
} 
No caso do Brasil, o conflito de interesses operava de acordo com o aparelho estatal por meio de intercâmbio, em que o Estado era dotado de fortes instrumentos coercitivos. Porém, ao passo que o setor operário perdia a interlocução com a estrutura corporativa devido à destruição das associações, o empresariado industrial conseguiu mantê-la. A inserção da classe empresarial no Estado foi permitida, portanto, pelo sistema corporativo de intermediação de interesses, o que resultou na transformação do Executivo em arena privilegiada para as demandas empresariais (Diniz, 1992).

Assim, o Estado brasileiro tornava-se mais seletivo em direção aos interesses capitalistas industriais. Tal direcionamento nas políticas poderia ser consequência da relevância dessas classes em temáticas caras ao Estado, como a questão do investimento como ressaltada por Offe (1984 [1972]).

Independente das causas, o aspecto fundamental aqui é o acesso diferenciado que determinadas classes - como o empresariado - possuem em relação ao aparato estatal e, consequentemente, à formulação de políticas, seja através de canais de contato com a burocracia ou por outros meios ${ }^{56}$. O impacto da riqueza consiste em permitir esse contato, devido ao seu papel na construção da posição social dos indivíduos e da aquisição de meios de influência política.

A predominância da classe empresarial é tão evidente, que alguns estudos, ao retratar a relação entre Estado e sociedade civil, focam majoritariamente nos canais de contato entre empresariado e aparato estatal ${ }^{57}$. O termo "sociedade civil" engloba muito mais que a classe empresarial; e o fato de um grupo específico ter acesso ao aparato estatal não implica em afirmar que outros grupos usufruem do mesmo contato.

Pelo contrário, o protagonismo da classe empresarial apenas demonstra o quanto essa classe possui um acesso diferenciado, isso é, em detrimento de muitos outros grupos que compõem a sociedade. No Brasil, esse aspecto é bastante relevante, tendo em vista a exclusão dos trabalhadores nos canais de acesso à burocracia pública (ver Diniz, 1992; Bresser-Pereira, 2007).

Assim, relatos sobre a história de construção do Estado brasileiro ressaltam a predominância de determinado segmento social - o empresariado - em detrimento de

\footnotetext{
${ }^{56}$ Tanto Poulantzas quanto Offe não descartam outros meios de ação, mas os consideram secundários em comparação com os mecanismos estruturais que descrevem.

${ }_{57}$ Ver, por exemplo: EVANS, Peter. Autonomia e Parceria: Estados e Transformação Industrial. Rio de Janeiro, Editora UFRJ, 2004.
} 
outros, contrastando tanto a tradição marxista quanto a segunda vertente. Entretanto, estudos mais precisos acerca da relação entre burocracia e classes sociais ainda são escassos.

Nota-se que estudos sobre a burocracia vêm crescendo no Brasil. Ainda assim, grande parte desses estudos foca em questões como os padrões de preenchimentos de cargos face ao presidencialismo de coalizão ou os critérios para nomeação, sem considerar o peso da ação burocrática para a democracia. Dessa forma, carece-se de uma abordagem que leve o debate democrático no sentido de analisar as consequências do recrutamento e da influência burocrática para o acesso da sociedade às instituições públicas.

De forma semelhante, há poucos estudos na Ciência Política brasileira sobre a influência dos grupos de interesse que atuam na articulação com o governo, principalmente dentro do debate sobre democracia. Provavelmente a escassez de estudos nessa área tem como uma das causas a falta de regulamentação acerca da atividade de lobby. No entanto, a ausência de leis que versem sobre a matéria não impede a atuação de diversos grupos dentro do Congresso e em constante articulação com o governo.

Esses grupos atuam geralmente por meio de entidades de representação de interesses, as quais podem ser oficiais ou não. No caso da indústria brasileira, por exemplo, destacam-se as federações e a Confederação Nacional da Indústria (CNI), que consiste na cúpula do setor industrial do Brasil. Mancuso (2003) mostra que a indústria brasileira atua ativamente na política para atender às demandas de sua agenda, obtendo resultados positivos para o setor.

O foco no legislativo foi desencadeado pela redemocratização, que reativou o papel protagonista do Congresso Nacional. Assim, por meio da interlocução com o Congresso, a CNI realiza ações de vigilância, acompanhamento, análise, tomada de posição, comunicação orientativa e exercício de pressão. Dessa forma, a entidade conta com funcionários que recolhem diariamente o material de relevância para o setor que ingressaram nas Casas do legislativo, além de acompanhar, analisar e pressionar positiva ou negativamente por proposições legislativas de interesse (Mancuso, 2003).

Já a comunicação orientativa consiste em comunicar o posicionamento acerca das matérias em tramitação às entidades que representam o setor e aos tomadores de decisão. A pressão política pode ocorrer tanto "por dentro" da produção legislativa, no caso de encontros oficiais e participação em audiências públicas ou reuniões, quanto "por fora", em 
que parlamentares e entidades se reúnem extraoficialmente. Grande parte do esforço de pressionamento acontece dentro das comissões temáticas, mas também abrange o plenário. As atividades de pressão não se restringem ao legislativo, pois ocorrem também em relação ao executivo, principalmente quando o conteúdo das proposições envolve seus segmentos (Mancuso, 2003).

Há muitos outros setores que atuam no Congresso por meio da ação de grupos de interesse. Poderiam ser citados como exemplos diversos grupos: as associações relacionadas à agropecuária, os movimentos em prol dos direitos humanos, os sindicatos e as empresas especializadas em lobby como a Patri e a Umbelino Lôbo, entre outras (ver Santos, 2007). Ademais, há o caso das frentes parlamentares, as quais são entidades suprapartidárias de cunho associativo que contam geralmente com o apoio de institutos e entidades de representação de classe. Além disso, muitas empresas possuem funções destinadas às "relações governamentais", atividades que incluem a articulação com órgãos do governo.

A atuação desses grupos na política em si não seria necessariamente negativa, caso não existisse um diferencial de acesso a esses grupos que, consequentemente, ocasiona um acesso diferenciado às instituições políticas no geral. Poderia se argumentar que a atividade dos grupos de interesses seria até mesmo fundamental em uma democracia, visto que se constitui em forma de articulação direta entre sociedade e Estado. Esse argumento está mais próximo da vertente pluralista, a qual considera que a existência de múltiplos grupos atuando na política impediria uma concentração de poder.

A vertente pluralista concentra-se, portanto, na definição de recurso. Nesse sentido, os recursos políticos encontram-se disseminados entre os atores sociais, o que corrobora para a dispersão da influência e consequentemente permite que tais atores atuem como freios e contrapesos às ambições uns dos outros (Mancuso, 2003).

O estudo de Dahl (1962) sobre a política em New Haven é paradigmático dessa perspectiva. A conclusão do autor incide acerca da competição desses grupos na esfera política, em que o governo atuaria como mediador. Sem entrar no mérito de possíveis equívocos quanto à metodologia empregada pelo autor ${ }^{58}$, essa perspectiva teórica prendese a duas falácias: primeiramente, considera que há "muitos" grupos atuantes na esfera

\footnotetext{
${ }^{58} \mathrm{O}$ estudo é realizado em cidade que provavelmente não é representativa do universo da população que se pretende estudar, apenas para citar um exemplo.
} 
política, sem comparar com os que estão excluídos dela; em segundo lugar, pode implicar em uma visão do Estado como "imparcial" ao colocá-lo como mediador de interesses. Ambas as problemáticas são questões centrais para o debate sobre a democracia ${ }^{59}$.

Além disso, há a questão das outras duas faces do poder: o poder não se limita a influenciar as decisões que fazem parte da agenda positiva, mas incluem também as "não decisões", isso é, às barreiras impostas ao escopo do processo decisório, além da incapacidade (imposta) de alguns grupos de formular seus interesses (Mancuso, 2003).

Bachrach e Baratz (1962) criticam justamente a desconsideração dessa segunda face do poder pelos cientistas políticos, principalmente aqueles que compartilham os pressupostos da vertente pluralista. Segundo os autores, os pluralistas tendem a focar a no exercício do poder em detrimento de suas fontes. No entanto, esse modelo apresentaria ao menos dois defeitos: não considera que o poder está relacionado com a diminuição do escopo da tomada de decisões e não estabelece critérios para a diferenciação entre assuntos importantes e não importantes.

Na medida em que uma pessoa ou um grupo - consciente ou inconscientemente cria ou fortalece barreiras ao público relativas a conflitos sobre políticas, essa pessoa ou grupo tem poder. O estudo de Dahl, por exemplo, foca nos assuntos políticos considerados chave, mas desconsidera aqueles que estão fora da agenda política, mas sobre os quais os variados grupos detêm influência (Bachrach e Baratz, 1962).

Sobretudo, muitos grupos e indivíduos continuam excluídos do sistema político. Tendo em vista que não são todos os membros da sociedade que são capazes de se articular por meio de grupos de interesses, os quais exigem diversos tipos de recursos, problematizar quais são os grupos que atuam e quem eles representam é fundamental.

Ademais, é pouco provável que todos os grupos detenham o mesmo potencial de influência nas decisões políticas. Seria necessário, portanto, analisar quais grupos conseguem influenciar mais efetivamente o processo político e quais são as razões desse sucesso. Dessa forma, a atribuição automática do ideal de imparcialidade ao aparato estatal impede a verificação de uma possível tendência em acatar certos interesses em detrimento de outros.

\footnotetext{
${ }^{59}$ Dentro do próprio pluralismo, há versões críticas que consideram a manutenção da desigualdade e do status quo como consequência da atividade dos grupos de interesses, os quais estão relacionados a perspectivas das classes mais privilegiadas ou do mundo dos negócios. O próprio Dahl admite que a difusão do poder para diferentes grupos não impede uma desigualdade na distribuição do poder (ver Santos, 2007).
} 
Mesmo que esse tipo de análise seja difícil de operacionalizar empiricamente, a omissão dos grupos de interesses nas discussões sobre teoria democrática no Brasil não é justificada. Com o pouco material existente sobre o assunto atualmente, ao menos algumas questões podem ser formuladas, de forma a orientar posteriores estudos. O primeiro conjunto de perguntas refere-se ao próprio mapeamento dos grupos que atuam nas instituições brasileiras: quais são os grupos e organizações que atuam na Câmara e no Senado? De que forma eles atuam? Como eles interagem com os parlamentares?

O segundo conjunto reflete os problemas de representatividade dos atuais regimes democráticos: quais são os interesses que estão sendo representados por grupos? Como eles se relacionam com classes ou estratos socioeconômicos da sociedade? Existe algum grupo ou organização que se destaque na influência exercida sobre o processo político? Tentar responder a essas questões trata de aprofundar a discussão sobre a desigualdade política: na medida em que determinados grupos ou organizações exercem mais influência sobre o sistema político, o poder está concentrado de certa forma, mesmo que distribuído entre uma quantidade razoável de grupos que diferem em ideologia e origem.

A questão ainda se agrava quando a quantidade de grupos atuantes no Congresso é representativa apenas de determinados interesses particulares em detrimento de grandes parcelas da população. Isso significa que falar na atuação de "muitos" grupos como equilíbrio do poder é ilusório, tendo em vista que os muitos representam, nesse caso, poucos segmentos da sociedade, estando a maior parte dela desprivada do poder político.

Assim, pessoas que se encontram de fora desses grupos que detém representação nas instituições políticas, por quaisquer razões, possuem menos acesso às decisões públicas. Mesmo que elas disponham de outros mecanismos de intervenção e controle, é de se questionar se tais instrumentos são tão efetivos quanto os grupos de interesses. Sobretudo, é preciso indagar acerca das variáveis que contribuem para a ação desses grupos e para o acesso de determinados segmentos da sociedade a eles.

O neomarxismo pode auxiliar a dar uma luz nessas questões, mesmo que não resolva o problema integralmente. Uma possível causa do diferencial de influência pode ser o potencial de pressão e represália por parte desses grupos. Notoriamente, o empresariado possui maiores condições de força política, não apenas devido à sua capacidade de organização, mas também ao poder econômico que detém e que se constitui na fonte das possibilidades de influência política. 
Por outro lado, a concentração de recursos econômicos contribui até mesmo para essa capacidade de organização, uma vez que permite arcar com custos relacionados à manutenção da estrutura dessas associações, entidades ou grupos. Assim, supõe-se que tais grupos arquem com os custos de aquisição de material e pessoal no desenvolvimento de suas atividades. Renda e riqueza influenciariam, portanto, na capacidade de membros e segmentos da sociedade em patrocinar ou sustentar tais grupos de interesse. Como destaca Santos (2007: 100) ao revisar a literatura sobre lobby e grupos de interesse:

Quanto à riqueza, trata-se, segundo Pasquino, de um elemento importante para que o grupo possa usufruir de consultores preparados e influentes, financiar campanhas eleitorais de partidos inteiros e de deputados e influenciar a opinião pública através da imprensa e da publicidade. Segundo LaPalombara, trata-se do "recurso primordial" requerido pelos grupos, que pode ser utilizado para "comprar muitos dos outros recursos que podem ser utilizados em situações politicamente conflituosas" (1982:328). No mesmo sentido, Schlozman e Tierney consideram o dinheiro o principal recurso político das organizações, e o que o torna importante é sua convertibilidade (1986:89) ou o fato de que pode ser transformado facilmente em outros recursos políticos valiosos. Trata-se, literalmente, do "poder de compra" do dinheiro.

O neomarxismo aborda pouco a atuação desses grupos por considerar que outros filtros sejam mais proeminentes. Porém, questiona-se aqui se um estudo aprofundando no peso que esses grupos possuem em termos de influência política e suas relações com a sociedade não seria pertinente, principalmente tendo em mente uma abordagem focada nas classes sociais e no acesso diferenciado que elas possuem ao sistema político.

Embora a maioria dos questionamentos delineados aqui corresponda apenas a hipóteses, resta a conclusão de que a atuação dos grupos de interesse não pode ser ignorada em uma agenda de pesquisa que busque compreender a dimensão dos problemas da democracia contemporânea. 


\section{IV \\ CONCLUSÃO}

De forma geral, pode-se argumentar que os fatores brevemente analisados no capítulo anterior referem-se a uma estrutura mais ampla de oportunidades de participação política. Ocupação de cargos eletivos, financiamento de campanhas, relacionamento com burocracia e grupos de pressão estão relacionados a oportunidades que indivíduos e grupos possuem de influenciar o sistema político, pois todos eles determinam o contato com as decisões públicas.

Tais oportunidades se relacionam em direção mútua com atributos considerados como "individuais", tais como capacidade, habilidades, senso de eficácia e motivação. Esses fatores taxados comumente como características inatas aos indivíduos possuem uma forte dimensão social, pois são afetados por determinantes sociais, como as possibilidades de socialização e o acesso a recursos essenciais, como educação e informação.

Assim, tais atributos não podem ser considerados como meramente "internos" aos indivíduos, visto que há uma dimensão relevante de socialização, em que o valor atribuído a capacidades específicas depende de uma construção social que legitima esses atributos como relevantes ou necessários. Dessa forma, determinantes influenciam atributos individuais socialmente construídos que, consequentemente, inferem na capacidade e no acesso dos cidadãos e cidadãs aos canais de interação com o sistema político.

A relação entre esses fatores apresenta também alguns sinais de mutualidade: ao passo que capacidades como oratória e negociação podem auxiliar na ampliação de determinadas oportunidades, a estrutura atual afeta diretamente a percepção dos indivíduos sobre a eficácia da própria participação. Nesse sentido, o contexto brasileiro é marcado por um forte distanciamento entre cidadão/ã comum e sistema político, em que as pessoas dispõem de poucos mecanismos de participação direta, enquanto há uma percepção geral de que há pouca efetividade na mobilização pública.

Dessa forma, as pessoas optam por não participar mais ativamente devido ao sentimento de que a ação coletiva não trará resultados. Esse sentimento, porém, não é um valor dado, mas uma percepção construída com base nas reais oportunidades existentes de participação, as quais são demasiadamente restritas. Ao definir democracia como 
distribuição igualitária de poder, nota-se a amplitude dos defeitos de alguns regimes autonominados como "democráticos", tendo em vista que a igualdade política é comprometida por uma série de fatores.

Um desses fatores corresponde à concentração de recursos econômicos, ilustrados em aspectos relativamente mensuráveis como renda e riqueza ${ }^{60}$. Renda e riqueza são fatores relevantes, pois estão relacionados a "caminhos" que levam os grupos e indivíduos ao sistema político. Isso significa que renda e riqueza associam-se a uma série de fatores que estão intrinsecamente relacionados às oportunidades de participação que ligam a sociedade à política. Vale ressaltar, contudo, que tais fatores não estão isolados, muitos deles interagem entre si. Renda, por exemplo, está ligada à educação, que por sua vez relaciona-se com trabalho, e os três incidem sobre a participação, como resume a figura 3.

Figura 3 - Relação entre condicionantes e acesso ao sistema político

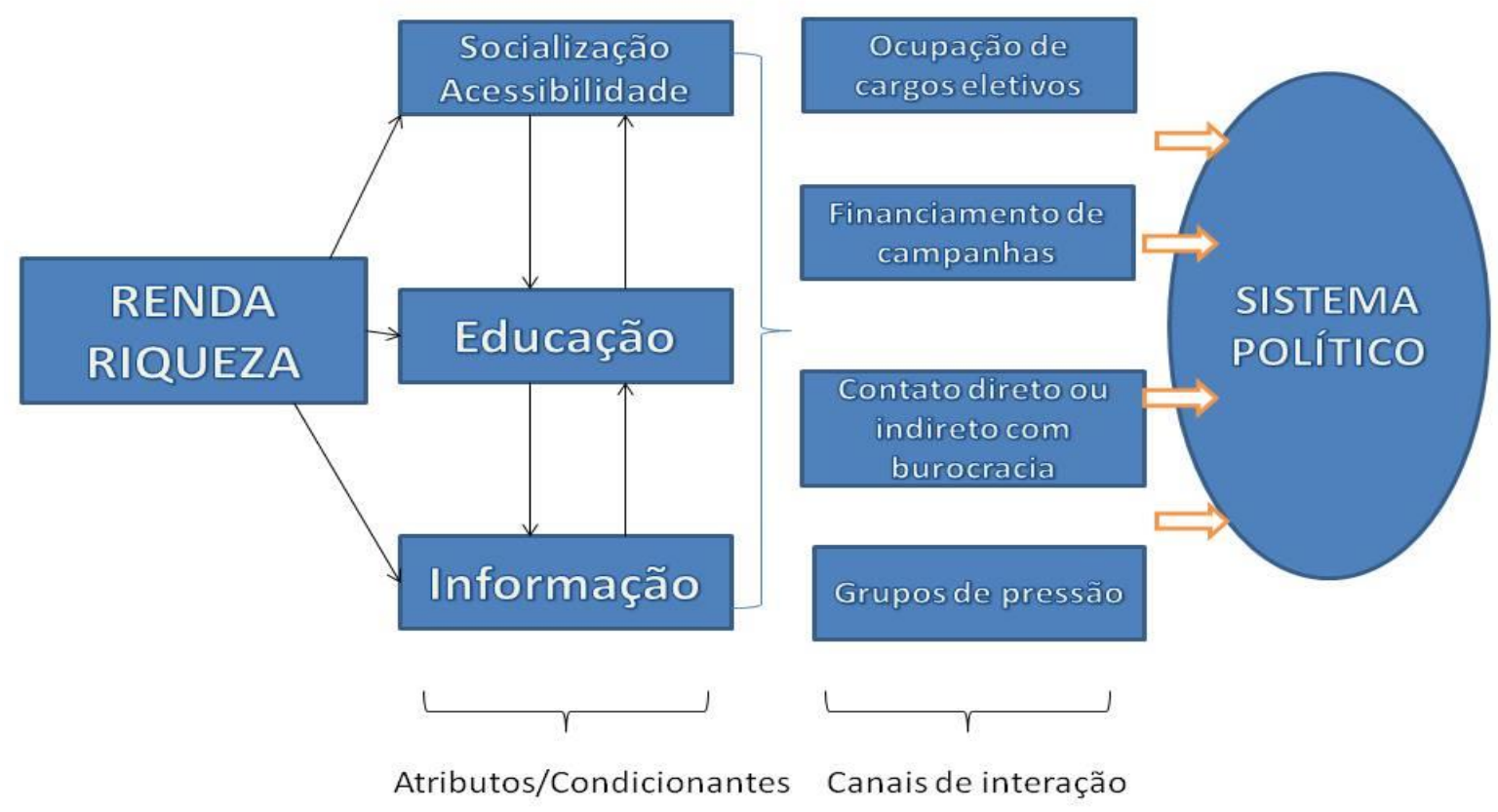

Cabe destacar ainda que embora ambas estejam relacionadas com recursos econômicos de maneira geral, renda e riqueza são variáveis distintas e consequentemente possuem impactos diversos sobre os diversos fatores analisados. Por exemplo, é razoável

\footnotetext{
${ }^{60}$ Há discordâncias, no entanto, sobre as formas mais adequadas de mensuração dessas variáveis, o que não deixa de passar por um debate sobre metodologia de pesquisa.
} 
supor que riqueza incida mais no financiamento de campanha que a renda em si, tendo em vista a predominância das pessoas jurídicas nessa esfera.

A questão central sobre a qual esse trabalho buscou refletir é como a distribuição de certos recursos econômicos incide na abertura do sistema político para determinados grupos ou indivíduos na sociedade em detrimento dos demais. Nesse sentido, conclui-se que é necessário redefinir os conceitos de seletividade e permeabilidade de forma a incluir todos os possíveis "caminhos” pelos quais o poder político é distribuído desigualmente.

Nesse contexto, seletividade passa a indicar o direcionamento diferenciado da política do Estado, enquanto permeabilidade compreende a abertura do Estado em relação aos grupos que compõem a sociedade. Dessa maneira, o sistema político pode ser mais ou menos permeável de acordo com a relação que mantém com esses grupos, que se baseia nos canais de comunicação e influência.

Tais canais abrangem os diversos caminhos expostos nesse trabalho, como a atividade de lobby e o financiamento de campanhas. Por outro lado, há uma série de atributos considerados como "individuais" que auxiliam a percorrer esses canais. Renda e riqueza incidem tanto nos canais em si quanto nos atributos necessários para atingi-los.

Utilizando a terminologia da sociologia de Bourdieu (1986, 2011), isso significa que o campo político é estruturado e restrito devido às suas regras de funcionamento, mas em vez de se abrir aos profanos apenas no período das eleições, há certas aberturas que são mais acessíveis a determinados grupos segundo uma série de fatores, que inclui elementos socioeconômicos.

Assim, verifica-se a existência de filtros que impedem o acesso dos profanos ao campo político, enquanto permitem a entrada facilitada por agentes que detém certos requisitos, entre eles a notável presença de determinados recursos econômicos. Em outros termos, essa tendência pode ser ilustrada pela conversão do capital econômico em capital político, mesmo que os agentes não estejam participando diretamente do campo.

Não se trata, portanto, apenas de participação, mas de uma participação efetiva: renda/riqueza influenciam na capacidade de participação em como as decisões públicas são tomadas diretamente, afetando menos outras modalidades de participação política. Dessa forma, há razões para acreditar que renda e riqueza afetam mais a influência política que certos indivíduos ou grupos detêm do que a participação em si entendida como conceito 
amplo. Essa diferença de influência política é crucial em contraposição ao conceito de democracia: ao passo que poder é distribuído de forma desigual, tem-se uma democracia demasiadamente limitada.

Durante os debates para as eleições presidenciais brasileiras de 2014, um tema frequentemente levantado por candidatos e eleitores foi a questão da reforma política. Supostamente, a reforma tem como objetivo o aperfeiçoamento do desempenho das nossas instituições democráticas. Todavia, o que chamamos de "reforma política" no Brasil abrange somente os aspectos institucionais, tais como regras partidárias e eleitorais.

A democracia, porém, não se restringe às regras formais. Parte relevante do funcionamento das instituições deve-se também ao comportamento dos cidadãos e cidadãs e do contato que eles possuem com o sistema político. Trata-se, na realidade, de uma relação bidirecional: enquanto regras contribuem para influenciar comportamentos individuais, atitudes de grupos e indivíduos afetam a forma com a qual as regras funcionam. Não adiantaria, por exemplo, prever uma série de mecanismos participativos na legislação nacional ${ }^{61}$, sem que os indivíduos e grupos que compõem a sociedade dispusessem dos recursos necessários para utilizar esses mecanismos.

Como se tentou demonstrar nesse trabalho, alguns dos recursos importantes para o fomento da participação política constituem-se em variáveis econômicas, como renda e riqueza. Distribuição de renda e riqueza relaciona-se com a democracia de forma a ilustrar a relação mútua entre padrões estruturais e institucionais. Renda e riqueza incidem sobre uma série de determinantes, os quais atuam sobre as oportunidades reais que indivíduos e grupos possuem em relação à interação com o sistema político, notadamente as instituições principais.

Isso não significa, porém, que distribuição de renda e riqueza seja o único fator que incide sobre a qualidade da democracia ou que outros aspectos sejam irrelevantes. Hierarquias de classe, gênero e raça são fatores que também podem condicionar as relações entre os indivíduos e o sistema político, comprometendo o acesso de determinados grupos à política. Dessa forma, medidas de redistribuição não se constituem na panaceia de todos os problemas referentes ao regime democrático, embora sejam fundamentais.

\footnotetext{
${ }^{61}$ No contexto brasileiro, o funcionamento de iniciativas como o Orçamento Participativo e os Conselhos é bastante ilustrativo: apesar dos avanços dessas iniciativas, elas nãos estão imunes às desigualdades estruturais, como aquelas derivadas de hierarquias pautadas em atributos como gênero e raça.
} 
Ademais, há outros tipos de fatores - como, por exemplo, a concentração de capital - que incidem sobre aspectos coletivos em vez de individuais. O modelo aqui apresentado focou em filtros que afetam estruturas de oportunidades em relação ao indivíduo em vez do grupo como unidade de análise.

Por outro lado, uma situação de plena igualdade econômica parece improvável. Assim, o que comumente se defende é que certo nível de igualdade econômica é necessário para um regime democrático substantivo, isso é, um regime de acesso mais igualitário pelos diferentes grupos que compõem a sociedade.

Tampouco renda e riqueza são os únicos elementos da desigualdade social. Desigualdade é primordialmente uma questão de acesso: a espaços, a serviços e principalmente a condições que estabelecem os padrões de vida. Dessa forma, serviços públicos de qualidade também podem ser classificados como medidas de redistribuição em certo sentido, mesmo não incidindo diretamente nos rendimentos. A desigualdade é, portanto, formada por várias dimensões, nas quais atuam diferentes fatores. Acredita-se, porém, que renda e riqueza ainda sejam fatores relevantes, principalmente em países marcados por fortes desigualdades estruturais, como o Brasil.

Grande parte da literatura na Ciência Política já abordava a relação positiva entre democracia e distribuição de renda, em ambas as direções de causalidade. Entretanto, a maioria abordava a questão como um aspecto da estabilidade democrática ou tratava a desigualdade econômica de forma muito genérica, sem especificar as razões que estariam entre as variáveis dependente e independente. As próprias definições de democracia frequentemente utilizadas em trabalhos e artigos acadêmicos ainda são bastante limitadas: focam nos aparatos institucionais disponíveis e não na utilização desses aparatos pelos indivíduos.

Não é surpreendente que os principais índices de mensuração da "qualidade" da democracia - como o Freedom House e o Polity IV - baseiem-se nesses fatores. Uma das razões possivelmente é a maior facilidade de operacionalização dessas regras em detrimento de outros fatores supostamente não mensuráveis. Entretanto, a quantificação da "democracia" é complicada por desconsiderar uma série de aspectos importantes de difícil tradução numérica.

Sobretudo, há razões para acreditar que a relação entre democracia e distribuição de renda e riqueza seja mútua, apresentando um aspecto de endogeneidade: ao passo que a 
teoria assinala que certo nível de igualdade econômica é necessário para a igualdade política, é plausível supor que quanto mais pessoas participem do sistema político, mais decisões dividirão os benefícios econômicos entre uma parcela maior da população. Dessa forma, a distribuição de renda e de riqueza pode ser simultaneamente uma variável dependente e independente ${ }^{62}$.

Ademais, a omissão de uma teorização mais específica e aprofundada acerca de como renda e riqueza afetam a democracia não é justificada. Tal negligência com a importância da concepção de "participação" no conceito de democracia ocorre até mesmo em trabalhos exclusivamente teóricos.

Assim, o modo com o qual a desigualdade econômica é vista em relação aos seus efeitos na democracia depende intrinsecamente do próprio conceito de democracia utilizado em termos da amplitude dada à concepção de participação e à relevância atribuída à igualdade política. No que tange ao conceito de democracia, a noção de distribuição de poder está presente desde a Grécia Antiga, em que os grupos socioeconômicos faziam parte da própria definição de democracia como forma de governo.

Até o modelo liberal-pluralista, que é muitas vezes visto como "limitado" pelas teorias críticas, contém implicitamente uma concepção de distribuição de poder quando discute a responsividade igual aos cidadãos/ãs e a correspondência entre indivíduo e voto. Mesmo que as eleições sejam um mecanismo de participação popular extremamente limitado, a regra de que um indivíduo detém apenas um voto traz a ideia de que cidadãos e cidadãs devam ter pesos iguais, o que novamente remete à definição de democracia como distribuição igualitária de poder.

Entretanto, o problema está na operacionalização desse conceito, visto que a mera presença de instituições formais não garante a participação igualitária efetiva. O deliberacionismo também traz a ideia de igualdade na questão das trocas discursivas, porém desconsidera uma série de fatores que contribuem para a formação de assimetria. Ademais, a democracia deliberativa pauta-se por uma separação ilusória entre "público" e "privado", o que pode comprometer a operacionalização de medidas eficazes para fomentar o "espírito democrático". Nota-se, assim, que há mutualidade entre instituições e

\footnotetext{
${ }^{62}$ É verdade que o problema da endogeneidade pode ser resolvido utilizando uma variável instrumental, mas torna mais complexa a análise do modelo.
} 
cultura política e que o funcionamento da democracia como previsto pela teoria depende de ambas.

O republicanismo e a democracia participativa, de forma geral, trazem mais explicitamente uma discussão sobre interação entre esfera econômica e política. A maioria das vertentes analisadas não traz, contudo, uma análise aprofundada da relação entre igualdade econômica e igualdade política, embora essa associação seja frequentemente mencionada.

A construção de uma teoria democrática marxista pode fornecer uma luz nesse sentido, visto que o foco do marxismo foi historicamente o impacto do poder econômico. Os conceitos de "seletividade" e "permeabilidade", se alargados de forma a abranger os diversos mecanismos de intervenção no sistema político, podem servir para posteriores desenvolvimentos de mensurações da qualidade da democracia. Nesse contexto, o principal atributo da democracia é a distribuição igualitária de poder político, analisada por meio da avaliação do diferencial de acesso de grupos ao sistema político. Enquanto o Estado for mais aberto - isso é, mais permeável - a determinados grupos em detrimento de outros, não há democracia plena.

Assim, evidencia-se que democracia também é uma questão primordialmente de classes: é preciso indagar quais classes possuem mais acesso ao Estado. O mecanismo opera conforme a relação entre renda, riqueza, posição social e acesso a recursos: pertencer à determinada classe social condiciona o acesso a determinados recursos que são necessários para ter contato direto com a política. Não por acaso as classes foram largamente enfatizadas não apenas na teoria política - desde sua origem grega - como nos debates sobre modernização.

Em outras palavras, o que se tentou abordar aqui foi o deslocamento entre democracia como regime e democracia como forma social. Abraçar a democracia como forma social requer mais do que mudar as regras institucionais. Uma reforma política que não inclua uma revolução social e econômica é, portanto, incompleta ou até mesmo inócua se não houver contrapartida nas estruturas sociais que condicionam o comportamento dos indivíduos. Assim, para trazer novamente sentido à frase de Victor Hugo, que postula a democracia como "defensora do povo", seria necessário devolvê-la aos cidadãos e cidadãs, para os quais o próprio conceito de "cidadania" deve ultrapassar o sentido limitado da igualdade formal. 


\section{BIBLIOGRAFIA}

ABU-EL-HAJ, Jawdat. Robert Dahl e o dilema da igualdade na democracia moderna. Análise Social, vol XLIII (1º), pp. 159-180, 2008.

AZEVEDO, Sérgio de; SANTOS JUNIOR, Orlando Alves dos; e RIBEIRO, Luiz César de Queiroz. Mudanças e permanências na cultura política das metrópoles brasileiras. Dados, vol. 52, n.3, pp. 691-733, 2009.

BACHRACH, Peter e BARATZ, Morton S. Two faces of power. American Political Science Review, vol. 53, no. 2. Washington, 1962.

BAYER, Gustavo F. Burocracia e política no Brasil: notas exploratórias. Revista de Administração Pública, 9 (1): 68-89, 1975.

BIROLI, Flávia e MIGUEL, Luis Felipe. Meios de comunicação, voto e conflito político no Brasil. Revista Brasileira de Ciências Sociais, vol. 28, nº 81, 2013.

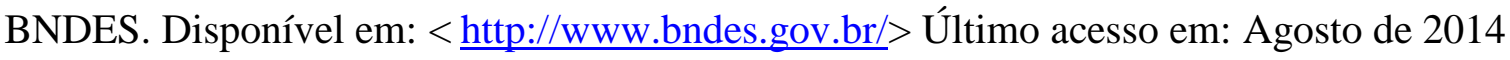

BOBBIO, Norberto. Liberalismo e Democracia. Tradução de Marco Aurélio Nogueira. São Paulo: Editora Brasiliense, 1988.

Teoria Geral da Política: A Filosofia Política e as Lições dos Clássicos. Rio de Janeiro: Elsevier, 2000.

BOURDIEU, Pierre. O poder simbólico. Lisboa: Difel, 1986.

O Campo Político. Revista Brasileira de Ciência Política, no 5, pp. 193-216, 2011.

BRESSER-PEREIRA, Luiz Carlos. Burocracia pública e classes dirigentes no Brasil. Rev. Sociol. Polit., Curitiba, 28, pp. 9-30, 2007.

CERVI, Emerson U. Financiamento de Campanha e desempenho eleitoral no Brasil: análise das contribuições de pessoas jurídicas, físicas e partidos políticos às eleições de 2008 nas capitais de Estado. Revista Brasileira de Ciência Política, nº 4, p. 135-167, 2010.

CODATO, Adriano; COSTA, Luiz Domingos. A profissionalização da classe política brasileira no século XXI: Um estudo do perfil sócio-profissional dos deputados federais (1998-2010). 35 Encontro Anual da ANPOCS (Caxambu - MG), GT16- Grupos dirigentes e estruturas de poder, 2011.

COSTA, Sérgio. Contextos da construção do espaço público no Brasil. Novos estudos, CEBRAP, nº 47, 1997, pp. 179-192.

COSTA, Paulo Roberto Neves; COSTA, Luiz Domingos; NUNES, Wellington. Os senadores-empresários: recrutamento, carreira e partidos políticos dos empresários no Senado brasileiro (1986-2010). Revista Brasileira de Ciência Política, nº 14, 2014. 
COUlAngES, Numa Denis Fustel de. The Ancient City: A Study on the Religion, Laws, and Institutions of Greece and Roma. Kitchener: Batoche Books, 2001. Disponível em: $\langle$ http://www.efm.bris.ac.uk/het/fustel/AncientCity.pdf $>$

DAHL, Robert. Who governs? Democracy and power in an american city. New Haven: Yale University Press, 1962.

. A Preface to Democratic Theory. Chicago: University of Chicago Press, 2006.

. Poliarquia: Participação e Oposição. Tradução de Celso Mauro Paciornik. São Paulo: Editora da Universidade de São Paulo, 2005.

A Preface to Economic Democracy. Berkeley e Los Angeles: University of California Press, 1985.

DELLI CARPINI, Michael X; KEETER, Scott. Democratic Theory to Democratic Practice. Em: What Americans Know About Politics and Why It Matters. New Haven: Yale University Press, 1996.

DINIZ, Eli. Neoliberalismo e Corporativismo: As duas faces do capitalismo industrial no Brasil. Revista Brasileira de Ciências Sociais, vol. 7, n. 20, 1992.

DOWNS, Anthony. Uma teoria econômica da democracia. Tradução de Sandra Guardini Teixeira Vasconcelos. São Paulo: Editora da Universidade de São Paulo, 1999.

FARIA, Claudia Feres. Democracia deliberativa: Habermas, Cohen e Bohman. Lua Nova, n 50, São Paulo, 2000, pp. 47-68.

FEDOZZI, Luciano J. . Democracia participativa, lutas por igualdade e iniquidades da participação. Em: FLEURY, Sonia; LOBATO, Lenaura de Vasconcelos Costa (Orgs.). Participação, Democracia e Saúde. Rio de Janeiro, 2009, v. 1, p. 204-228.

FUKUYAMA, Francis. The End of History? The National Interest, 1989. Disponível em: 〈http://www.kropfpolisci.com/exceptionalism.fukuyama.pdf> Último acesso: $04 \mathrm{de}$ Setembro de 2013.

FRASER, Nancy. Rethinking the Public Sphere: A Contribution to the Critique of Actually Existing Democracy. Social Text, $\mathrm{n}^{\mathrm{o}}$ 25/26, 1990, pp. 56-80.

Da Redistribuição ao Reconhecimento? Dilemas da Justiça na era Pós-Socialista. In: SOUZA, Jessé (org.) Democracia Hoje: Novos desafios para a teoria democrática contemporânea. Brasília: Editora UnB, 2001, p.245-282.

Social Justice in the Age of Identity Politics: Redistribution, Recognition, and Participation. Em FRASER, Nancy \& HONNETH, Axel. Redistribution or Recognition : a Political-Philosophical Exchange. London: Verso, 2003.

FINLEY, Moses. Democracia antiga e moderna. Tradução de Waldéa Barcellos e Sandra Bredan. Revisão técnica de Neyde Theml. Rio de Janeiro: Graal, 1988. 
FLEURY, Sonia. Democracia, descentralização e desenvolvimento. Em: democracia, descentralização e desenvolvimento: Brasil e Espanha. Rio de Janeiro: FGV, 2006.

GALVÃO, Marisa Nunes e CIFUENTES, Ricardo. Cooperação, autogestão e educação nas novas configurações do trabalho. Revista ORG \& DEMO, n.2, 2001.

GANANÇA, Alexandre Ciconello. Associativismo no Brasil: Características e limites para a construção de uma nova institucionalidade participativa. Dissertação apresentada no Instituto de Ciência Política na Universidade de Brasília. 2006.

HABERMAS, Jürgen. The Structural Transformation of the Public Sphere: An Inquiry into a Category of Bourgeois Society. Tradução: Thomas Burger. Cambridge: The MIT Press, 1991.

. Direito e Democracia: Entre Facticidade e Validade. Rio de Janeiro: Tempo Brasileiro, 1997.

HEDSTRÖM, Petri \& YLIKOSKI, Peter. Causal Mechanisms in the Social Sciences. Annual Review of Sociology, 36: 49-67, 2010.

HELD, David. Modelos de democracia. Tradução de María Hernández. Madrid: Alianza, Terceira Edição, 2007. . Models of democracy. $3^{\text {a }}$ Edição. Stanford: Stanford University Press, 2006.

HEYWOOD, Andrew. Political Theory: an introduction. Nova York: Palgrave Macmillan, 2004.

IBGE. <http://www.ibge.gov.br/home/>

LIPSET, Seymour Martin. Social Requisites of Democracy: Economic Development and Political Legitimacy. American Political Science Review, Vol 53, No 1, 1959. Pp. 69-75. Disponível em: http://www.jstor.org/stable/1951731 (Último acesso: 03 de março de 2014)

LOCKS, Pompilio e GUGLIANO, Alfredo Alejandro. Democracia e economia solidária: limitações e potencialidades. Revista Brasileira de Ciência Política, nº 10, 2013.

LOUREIRO, Maria Rita; OLIVIERI, Cecília; MARTES, Ana Cristina Braga. Burocratas, partidos e grupos de interesse: o debate sobre política e burocracia no Brasil. Em: Maria Rita Loureiro, Fernando Luiz Abrucio, Regina Silvia Pacheco (Orgs). Burocracia e política no Brasil: desafios para a ordem democrática no século XXI. Rio de Janeiro: Editora FGV, 2010.

LUBENOW, Jorge Adriano. "A categoria de esfera pública em Jürgen Habermas: para uma reconstrução da autocrítica". Cadernos de Ética e Filosofia Política 10, pp. 103-123, 2007.

LUPIA, Arthur e MCCUBBINS, Mathew. "The Institutional Foundations of Political Competence: How Citizens Learn What They Need to Know". Em: Elements of Reason: 
Cognition, Choice, and the Bounds of Rationality. Cambridge, Cambridge University Press, 2000.

LUSKIN, Robert; FISHKIN, James e JOWELL, Roger. "Considered Opinions: Deliberative Polling in Britain.” British Journal of Political Science. 32: pp. 455-87, 2002.

MACFARLANE. Leslie John. Teoria Política Moderna. Brasília: Editora Universidade de Brasília. 1970.

MANCUSO, Wagner Pralon. O lobby da indústria no Congresso Nacional: empresariado e política no Brasil contemporâneo. Grupo de Trabalho $\mathrm{n}^{\mathrm{o}} 5$ (Empresariado e Ação Coletiva), $27^{\circ}$ Encontro Anual da Associação Nacional de Pós-graduação e Pesquisa em Ciências Sociais, Caxambu, Minas Gerais, 21-25 de outubro, 2003.

MANIN, Bernard. The principles of representative government. Cambridge: Cambridge University Press, 1997.

MARQUES, Danusa. Democracia e ciências sociais no Brasil (1985-2005). Dissertação de mestrado apresentada ao Instituto de Ciência Política da Universidade de Brasília, 2007.

MARX, Karl. A Mercadoria. O Capital: crítica da economia política. Rio de Janeiro: Civilização Brasileira, 1970.

MEDEIROS, Marcelo; SOUZA, Pedro Herculano G. Ferreira de; CASTRO, Fabio Avila de. "O Topo da Distribuição de Renda". No Brasil: Primeiras Estimativas com Dados Tributários e Comparação com Pesquisas Domiciliares, 2006-2012”. 2014. Disponível em: http://papers.ssrn.com/sol3/Papers.cfm?abstract_id=2479685 (Último acesso: 07/11/2014).

MEDEIROS, Marcelo; SOUZA, Pedro Herculano G. Ferreira de. Estado e desigualdade de renda no Brasil: fluxo de rendimentos e estratificação social. Revista Brasileira de Ciências Sociais, vol. 28, nº 83, 2013.

MELO, Marcus André. Republicanismo, Liberalismo e Racionalidade. Lua Nova (revista de cultura e política), $n^{\circ} 55-56,2002$, pp. 57-84.

MIGUEL, Luis Felipe. A Democracia Domesticada: As Bases Antidemocráticas do Pensamento Democrático Contemporâneo. DADOS - Revista de Ciência Sociais, Rio de Janeiro, 2002 Vol 45, n³, pp. 483-511.

Capital político e carreira eleitoral: algumas variáveis na eleição para o Congresso brasileiro. Rev. Sociol. Polít. Curitiba, 20, p. 115-134, 2003.

Mídia e vínculo eleitoral: a literatura internacional e o caso brasileiro. Opinião Pública. Campinas, Vol. X, nº 1, 2004, pp. 91-111.

Teoria Democrática Atual: Esboço de Mapeamento. Em: Revista Brasileira de Informação Bibliográfica em Ciências Sociais, n 59. São Paulo: Editora da Revista BIB, 2005. P. 5-42. 
MINELLA, Ary Cesar. Globalização financeira e as associações de bancos na América Latina. Civitas - Revista de Ciências Sociais, v. 3, nº 2, 2003.

MINISTÉRIO DO PLANEJAMENTO, ORÇAMENTO E GESTÃO (MP). Boletim Estatístico de Pessoal e Informações Organizacionais. Brasília, Vol. 19 n.219 (Jul 2014). Disponível em: http://www.planejamento.gov.br/secretarias/upload/Arquivos/servidor/publicacoes/boletim _estatistico_pessoal/2014/Bol219_jun2014_parte_I.pdf (último acesso: 15/10/2014).

MOORE, Barrington. Social Origins of Dictatorship and Democracy: Lord and Peasant in the Making of the Modern World. Harmondsworth: Penguin, 1974.

MOUFFE, Chantal. El retorno de lo politico: comunidad, ciudadanía, pluralismo, democracia radical. Barcelona: Paidós, 1999.

OFFE, Claus. Problemas estruturais do Estado capitalista. Rio de Janeiro: Tempo Brasileiro, 1984.

OKIN, Susan. Is multiculturalism bad for women? Em: COHEN, Joshua e HOWARD, Matthew (eds.), Is multiculturalism bad for women? Princeton: Princeton University Press, 1999.

OLSON, Mancur. A Lógica da Ação Coletiva: os benefícios públicos e uma teoria dos grupos. São Paulo: EDUSP, 1991.

PATEMAN, Carole. Participação e teoria democrática. Rio de Janeiro: Paz e Terra, 1992.

PIKETTY, Thomas. Le Capital au XXIe siècle. Paris : Éditions du Seuil, 2013.

PHILLIPS, Anne. Multiculturalism without culture. Princeton: Princeton University Press, 2007.

PLATÃO. A República. Coleção “Os Pensadores”. São Paulo: Nova Cultural, 2000.

POLÍTICA ABERTA. Disponível em: <http://www.politicaaberta.org> Último acesso: 2014.

POULANTZAS, Nicos. O Estado, o poder, o socialismo. Rio de Janeiro: Edições Graal, $4^{\mathrm{a}}$ edição, 2000.

PRZEWORSKI, Adam. Democracy, Equality, and Redistribution. Em: BOURKE, Richard e GEUSS, Raymond. Political Judgement. Cambridge: Cambridge University Press, 2009. Capítulo disponível em: 〈http://politics.as.nyu.edu/docs/IO/2800/equality_dunn.pdf>

PUTNAM, Robert. Comunidade e democracia: a experiência da Itália moderna. (Tradução: Luiz Alberto Monjardim). Rio de Janeiro: Fundação Getúlio Vargas, 1996.

RESENDE, João Francisco; CHAGAS, Juliana Sawaia Cassiano. Eleições no Brasil em 2010: comparando indicadores político-eleitorais em surveys e na internet. IV Congresso Latino-Americano de Opinião Pública da WAPOR - World Association of Public Opinion Research, Belo Horizonte, 2011. 
ROUSSEAU, Jean-Jacques. Discurso sobre a origem e os fundamentos da desigualdade entre os homens. Coleção “Os Pensadores”. São Paulo: Nova Cultural, 1988.

RUESCHEMEYER, Dietrich; STEPHENS, Evelyne Huber; STEPHENS, John D. Capitalist Development and Democracy. Cambridge: Polity Press, 1992.

SANTOS, Luiz Alberto. Regulamentação das atividades de lobby e seu impacto sobre as relações entre políticos, burocratas e grupos de interesse no ciclo de políticas públicas análise comparativa dos Estados Unidos e Brasil. Tese de doutorado apresentada ao Programa de Pós-Graduação em Estudos Comparados sobre as Américas, Brasília, dezembro de 2007.

SCHNEIDER, Ben Ross. Hierarchical Markets Economies and Varieties of Capitalism in Latin America. OCSID Working Paper, 2009.

SCHUMPETER, Joseph. Capitalismo, Socialismo e Democracia. Rio de Janeiro: Editora Fundo de Cultura, 1961.

SELL, Carlos Eduardo. Ideologias políticas. Introdução à Sociologia Política. Petrópolis: Vozes, 2006.

SILVA, Filipe Carreira da. "Habermas e a esfera pública: reconstruindo a história de uma ideia”. Sociologia, Problemas e Práticas. Lisboa, no 35, 2001, pp. 117-138.

SILVA, Idalice Ribeiro. Natureza e história: os sentidos da liberdade e da igualdade. Educação e Filosofia. 8 (16) 35-76, 1994.

SINGER, Paul. Economia Solidária: democracia e conflitos entre iguais. Otra Economia. Volume 1, $\mathrm{n}^{\circ} 1,2007$.

SINGER, André. Os sentidos do lulismo. Reforma gradual e pacto conservador. São Paulo: Companhia das Letras, 2012.

SOUZA, Jessé. A singularidade ocidental como aprendizado reflexivo: Jürgen Habermas e o conceito de esfera pública. Em: SOUZA, Jessé. A modernização seletiva: Uma reinterpretação do dilema brasileiro. Brasília: Editora da Universidade de Brasília, 2000.

SPECK, Bruno W. Três ideias para oxigenar o debate sobre dinheiro e política no Brasil. Debate, Belo Horizonte, vol. 2, n. 3, 2010.

SPINNER-HALEV, Jeff. Multiculturalism and its critics. Em: DRYZEK, John; HONIG, Bonnie e PHILIPS, Anne. The Oxford Handbook of Political Theory. Oxford: Oxford University Press, 2006.

SZTUTMAN, André Medeiros; ALDRIGHI, Dante Mendes. Financiamento das campanhas eleitorais de 2006 por grupos econômicos e empréstimos do BNDES. Encontro da ANPEC: Área 4 - Economia do Setor Público, 2012.

TAVARES, Francisco Mata Machado. A Democracia Realizada do Materialismo Histórico: sobre a ditadura do proletariado e sua injustificada omissão nos estudos de 
teoria democrática contemporânea. $2^{\circ}$ Simpósio Nacional sobre Democracia e Desigualdades, Brasília, 2014.

TILLY, Charles. Regimes and repertoires. Estados Unidos: Chicago University Press, 2006.

TSE. Repositório de dados eleitorais. Disponível em: $<$ http://www.tse.jus.br/eleicoes/estatisticas/estatisticas-eleicoes-2012> Último acesso: Agosto de 2014.

VERBA, Sidney, SCHLOZMAN, Kay e BRADY, Henry. Voice and Equality: Civic Voluntarism in American Politics. Cambridge: Harvard University Press, 1995.

YOUNG, Iris Marion. Justice and the politics of difference. Princeton: Princeton University Press, 1990.

WRIGHT, Erik Olin. Interrogating Inequality: essays on class analysis, socialism and Marxism. Londres: Verso, 1994.

WUCHERPFENNIG, Julian; DEUTSCH, Franziska. Modernization and democracy: Theories and evidence revisited. Living Reviews in Democracy (Center for Comparative and International Studies), 2009. Disponível em: http://democracy.livingreviews.org/index.php/lrd/article/viewarticle/lrd-2009-4/13 (Último acesso: 03 de março de 2014) 